RAPHAEL FAGNANI SANCHEZ MOLINA

\title{
EFEITO DE TERAPIAS NA MODULAÇÃO DO GRANULOMA PARACOCCIDIOIDOMICÓTICO
}

Dissertação apresentada ao Programa de PósGraduação em Imunologia do Instituto de Ciências Biomédicas da Universidade de São Paulo para obtenção do Título de Mestre em Ciências.

SÃO PAULO

2010 
RAPHAEL FAGNANI SANCHEZ MOLINA

\section{EFEITO NA MODULAÇÃO DO GRANULOMA PARACOCCIDIOIDOMICÓTICO}

Dissertação apresentada ao Programa de PósGraduação em Imunologia do Instituto de Ciências Biomédicas da Universidade de São Paulo para obtenção do Título de Mestre em Ciências.

Área de concentração: Imunologia Orientadora: Profa. Dra. Eva Burger

SÃO PAULO 2010 
DADOS DE CATALOGAÇÃO NA PUBLICAÇÃO (CIP)

Serviço de Biblioteca e Informação Biomédica do

Instituto de Ciências Biomédicas da Universidade de São Paulo

reprodução não autorizada pelo autor

\section{Molina, Raphael.}

Efeito de Terapias na Modulação de Granuloma

Paracoccidioidomicótico / Raphael Molina. -- São Paulo, 2010.

Orientador: Eva Burger.

Dissertação (Mestrado) - Universidade de São Paulo. Instituto de Ciências Biomédicas. Departamento de Imunologia. Área de concentração: Imunologia. Linha de pesquisa: Imunopatologia das micoses

Versão do título para o inglês: Effect of Therapy on Paracoccidioidomicotic Granuloma Modulation.

Descritores: 1. Granuloma 2. Paracoccidioidomicose 3. Metaloproteinases 4. Colágeno I. Burger, Eva

II. Universidade de São Paulo. Instituto de Ciências Biomédicas.

Programa de Pós-Graduação em Imunologia III. Título. 


\section{UNIVERSIDADE DE SÃO PAULO \\ INSTITUTO DE CIÊNCIAS BIOMÉDICAS}

Candidato(a):

Raphael Fagnani Sanchez Molina.

Título da Dissertação:Avaliação funcional de células T reguladoras geradas in vitro na modulação da resposta imune.

Orientador(a):

Eva Burger.

A Comissão Julgadora dos trabalhos de Defesa da Dissertação de Mestrado, em sessão pública realizada a ..$/ \ldots \ldots \ldots \ldots \ldots \ldots \ldots \ldots \ldots \ldots \ldots$
( ) Aprovado(a)
( ) Reprovado(a)

Examinador(a):Assinatura:

Nome:

Instituição:

Examinador(a):Assinatura:

Nome:

Instituição:

Presidente: Assinatura:

Nome:

Instituição: 


\section{Certificado}

Certificamos que o protocolo registrado sob $\mathrm{n}^{\circ} \mathbf{0 0 3}$ nas fls do livro 53 para uso de animais em experimentação, sob a responsabilidade de Eva Burger, Coordenador(a) da Linha de pesquisa "Emprego de terapias no granuloma paracoccidioidomicótico" do qual participou(aram) o(s) alunos Raphael Fagnani Sanchez Molina, Ângela Satie Nishilalu, Luciana Cristina Ribeiro está de acordo com os Princípios Éticos de Experimentação Animal adotado pelo Colégio Brasileiro de Experimentação Animal (COBEA) e foi aprovado pela COMISSĀO DE ÉTICA EM EXPERIMENTAÇÃO ANIMAL (CEEA) em 26.02.08, com validade de 3 anos.

São Paulo, 27de fevereiro de 2008.

\section{uetroma.}

Prof. Dr. Wothan TAVARES DE LIMA Coordenador CEEA - ICB/USP

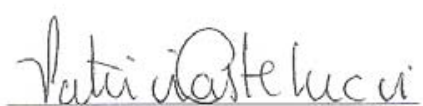

Profa. Dra. PATrícia CASTELUCCI Secretária CEEA - ICB/USP 
A todos que acreditaram. 


\section{AGRADECIMENTOS}

Eu gostaria de agradecer a todos que tiveram uma parcela deste tão sonhado titulo. Minha orientadora Eva Burger, que sempre confiou no meu trabalho e nunca ou quase nunca perdeu a paciência com seu aluno. Ensinou-me como é bonita a pesquisa e a vida acadêmica, era minha orientadora dos meus projetos e da minha vida. Muito Obrigado.

Minha namorada Renata Salton, que sempre me deu força para terminar todo o meu trabalho, foi ela quem me dava força, quando eu não tinha mais de onde tira-la. Ajudou-me em tudo que eu pedi e sem ela, dificilmente conseguiria terminar este trabalho. Te amo amor!!

Minha família, que tenho certeza está muito orgulhosa por eu conseguir realizar este sonho. Foram os primeiros a me incentivar, sempre me deram o suporte e o apoio durante toda a minha vida, a eles, devo tudo o que tenho e conquistei.

Todos do meu laboratório, durante o período que fiz meus trabalhos, Renata Scavone, Ângela Nishikaku, Claudia Cunha, Célia Pizzo, Luciana e Vicente, todos me ajudaram muito, e sempre foram mais amigos, do que companheiros de laboratório.

A todos os meus amigos do ICB, da faculdade e da vida, por que afinal a vida não é feita apenas de trabalho. 
Aí sim fomos surpreendidos novamente!

(Mario Jorge Lobo Zagallo) 


\section{RESUMO}

MOLINA, R. F. S. Efeitos de terapias na modulação do granuloma paracoccidioidomicótico. 2010. 115 f. Dissertação (Mestrado em Imunologia) Instituto de Ciências Biomédicas, Universidade de São Paulo, São Paulo, 2010.

A paracoccidioidomicose ( $P C M)$ é uma micose sistêmica endêmica na América Latina, cujo agente etiológico é o fungo termo-dimórfico Paracoccidioides brasiliensis $(\mathrm{Pb})$. A PCM é caracterizada por ser uma doença granulomatosa; a formação do granuloma pode ser compreendida como um mecanismo do organismo para bloquear e circunscrever o fungo ou seus componentes antigênicos, uma vez impossibilitado de lisá-los. As formas benignas da doença são caracterizadas por uma infecção localizada, contendo granulomas compactos com poucos fungos; já nas formas mais graves, ocorre um processo granulomatoso frouxo com focos de necrose e intensa disseminação fúngica. Estudos da resposta granulomatosa desenvolvida em camundongos resistentes (A/J) e susceptíveis (B10.A) ao isolado $\mathrm{Pb} 18$ evidenciaram a presença de distintos padrões de lesões relacionada ao tipo de composição da matriz extracelular (MEC) e às diferentes células presentes, sugerindo um papel importante destes elementos na formação e constituição do granuloma e por conseguinte na resolução ou não da infecção. Em nosso projeto, objetivou-se avaliar o desenvolvimento de lesões granulomatosas em baço, fígado, pulmão e epiplon de camundongos susceptíveis a PCM, após infecção pela via intraperitoneal com o isolado de alta virulência, $\mathrm{Pb} 18$, em diferentes períodos de infecção (fase aguda e crônica) após tratamento com fármacos, os quais possuem mecanismo de ação intimamente relacionado com a alteração no balanço entre a síntese e degradação dos produtos do colágeno, interferindo diretamente na formação do granuloma e na manutenção da viabilidade dos fungos, correlacionando com o aparecimento de fibrose, que afinal é uma seqüela freqüente e incapacitante de numerosas infecções entre elas a PCM, tendo como característica a proliferação de fibroblastos e depósito de MEC. Os tratamentos foram escolhidos com base em conhecimentos prévios, e associando alguns de seus efeitos com a interferência no curso da PCM experimental murina. A citocina 
IFN- $\gamma$ foi empregada pelo seu efeito antifibrótico, por ser ativador de macrófagos na infecção por $P$. brasiliensis e um dos responsáveis pelo aumento do efeito fungicida de neutrófilos. $O$ antibiótico Tetraciclina foi empregado por possuir efeito inibitório sobre a síntese de matriz extracelular, limitando a capacidade de degradação das colagenases, além de atividade antimicrobiana. Finalmente, as drogas antiinflamatórias Lumiracoxib e Celecoxib, foram utilizadas pela demonstração que estes inibidores específicos da enzima COX-2 aumentam a expressão de colágeno tipo III e IV. Avaliamos a presença de alguns componentes do granuloma (colágeno, células do infiltrado inflamatório, de citocinas primordiais para sintese/degradação da MEC do granuloma, presença de $P$. brasiliensis). Entre as citocinas analisadas, estudamos o TNF- $\alpha$ pela sua ação após ser secretados de macrófagos, e sua importância na formação do granuloma e na regulação da secreção da metaloproteinase (MMP) com função de colagenase, MMP-9, o TGF- $\beta$ por modular negativamente a secreção de oxido nítrico por macrófagos e promover o acúmulo de MEC e que se acredita ser o mediador central do processo de fibrose em diversas patologias e o IFN- $\gamma$ por estar correlacionado à resposta imune preferencial Th1 em processos infecciosos de natureza fúngica e bacteriana e efeito modulador da ação dos fibroblastos.

Palavras chave: Granuloma. Paracoccidioidomicose. Metaloproteinases. Colágeno. 


\begin{abstract}
MOLINA, R. F. S. Effect of therapy on paracoccidioidomicotic granuloma modulation. 2010. 115 p. Master thesis (Immunology) - Instituto de Ciências Biomédicas, Universidade de São Paulo, São Paulo, 2010.
\end{abstract}

Paracoccidioidomycosis (PCM) is a systemic mycosis that is endemic in Latin America, whose causative agent is the thermal dimorphic fungus Paracoccidioides brasiliensis $(\mathrm{Pb})$. PCM is a granulomatous disease, and the formation of granulomas can be understood as a mechanism of the body to block and limit the invasiveness of the fungus or its antigenic components, once unable to lyse them. Bening forms of the disease are characterized by a localized infection, where granulomasa are compact and contain few fungi. More severe forms present loose granulomatous processes with foci of necrosis and severe fungal. Studies in which granulomatous response was developed in resistant (A/J) and susceptible (B10.A) mice to the high virulence isolate $\mathrm{Pb} 18$ showed the presence of different patterns of injuries related to the type of extracellular matrix (ECM) components and the different cells types in the area, suggesting a important role of these elements in the formation and constitution of the granuloma and thus the outcome of infection. In our project, we aimed to evaluate the development of granulomatous lesions in the spleen, liver, lung and omentum of mice susceptible to PCM after intraperitoneal infection with $\mathrm{Pb} 18$, at different periods of infection (acute and chronic) with or without treatment with drugs. These drugs have mechanisms of action closely related to the change in the balance between synthesis and degradation of collagen Thus, they interfere directly in the granuloma formation and in maintaining the viability of fungi and also with the development of fibrosis. Which is a common and devastating sequelae of numerous infections including the PCM, with the characteristic proliferation of fibroblasts and deposition of ECM. The treatments were chosen based on prior knowledge on their effects on the course of experimental murine PCM. IFN- $\gamma$ was chosen due to its antifibrotic effect, being an activator of macrophages in infection by $P$. brasiliensis and increasing the fungicidal effect of neutrophils. The antibiotic tetracycline was used because of its inhibitory effect on the synthesis of extracellular matrix, limiting antimicrobial activity and the ability of collagenase to degrade ECM. Finally, the antiinflammatory drugs Celecoxib and Lumiracoxib (inhibitors of the COX-2 enzyme) 
were used because they cause an increase in the expression of collagen type III and type IV. We analyzed the components of the granuloma (collagen, inflammatory cells, cytokines essential for synthesis / degradation of the ECM of the granuloma, the presence of $P$. brasiliensis). Among the cytokines analyzed, we studied the importance of TNF- $\alpha$ in the formation of granulomas and regulation of matrix metalloproteinases (MMP) synthesis and function. We analyzed TGF- $\beta$ because it negatively modulate the secretion of nitric oxide by macrophages and promote the accumulation of ECM and is believed to be the central mediator of the process of fibrosis in several pathologies. IFN-g was studied because of its correlation to the preferential Th1 immune response in diseases and infectious processes of fungal and bacterial infections, and also because it modulates fibroblast function.

Keywords: Granuloma. Paracoccidioidomycosis. Metalloproteinase. Collagen. 


\title{
LISTA DE ABREVIATURAS E SIGLAS
}

\author{
ABS - Albumina sérica bovina \\ CFU - Unidades formadoras de colônias \\ coX - Ciclooxigenase \\ GM-CSF - Fator estimulador de colônias de granulócitos e macrófagos \\ $\mathrm{H}_{2} \mathrm{SO}_{4}$ - Ácido sulfúrico \\ HE - Hematoxilina e eosina \\ IFN-Y - Interferon-y \\ Ip -Intraperitoneal \\ MEC - Matriz extracelular \\ membrane-type MMPs - MT-MMPs - MMPs do tipo membrana \\ MMPs - Metaloproteases \\ NADPH oxidase - Dinuclaotídeo nicotinamida-adenina-fosfato oxidase \\ NEED - N,N,N',N'-tetrametiletilenediamina \\ NK - Natural Killers \\ NO - Óxido nítrico \\ OPA - Ortofetaldialdeído \\ OPD - Ortofenilenidiamina \\ OPD - ortofenilenidiamina \\ PCM - Paracoccidioidomicose \\ RPHPLC - hidroxiprolina foi realizada através de cromatografia liquida de alta \\ performance reversa \\ SFB - Soro fetal bovino \\ TBS - Salina tamponada com Tris \\ TGF- $\boldsymbol{\beta}$ - Fator de crescimento tumoral \\ TIMPs - Metaloproteases da matriz \\ TNF- $\alpha$ - Fator de necrose tumoral
}




\section{LISTA DE FIGURAS}

Figura 1 - Quantificação de fungos viáveis em camundongos B10.A inoculados com Pb18 e submetido a um dos tratamentos (IFN- $\gamma$; Tetraciclina; Lumiracoxib; Celecoxib) ou apenas infectados, aos 15 dias de infecção.

FIGURA 2 - QUANTIFICAÇÃO DE FUNGOS VIÁVEIS EM CAMUNDONGOS B10.A INOCULADOS COM PB18 E SUBMETIDO A UM dos TRATAMENTOS (IFN- $\gamma$; TETRACICLINA; LUMIRACOXIB; Celecoxib) ou apenas INFECtados, aOS 15 dias de INFECÇÃo. .50

FIgURA 3 - QUANTIFICAÇÃO DE FUNGOS VIÁVEIS EM CAMUNDONGOS B10.A INOCULADOS COM PB18 e SUBMETIDO A UM dOS TRATAMENTOS (IFN- $\gamma$; TETRACICLINA; LUMIRACOXIB) OU APENAS INFECTADOS, AOS 120 DIAS DE INFECÇÃO.

FIGURA 4 - QUANTIFICAÇÃO DE FUNGOS VIÁVEIS EM CAMUNDONGOS B10.A INOCULADOS COM PB18 e SUBMETIDO A UM dOS TRATAMENTOS (IFN- $\gamma$; TETRACICLINA; LUMIRACOXIB) OU APENAS INFECTADOS, AOS 120 DIAS DE INFECÇÃO.

Figura 5 - Determinação da concentração de NO, mensurado sob a forma de nitrito, em camundongos B10.A inoculados com Pb18 e submetido a um dos tratamentos (IFN- $\gamma$; Tetraciclina; Lumiracoxib; Celecoxib) ou apenas infectados, aos 15 dias de infecção

Figura 6 - DETERMINAÇÃo DA CONCENTRAÇÃO DE NO, MENSURADO SOB A FORMA DE NITRITO, EM CAMUNDONgos B10.A INOCULAdOS COM PB18 E SUBMETIDO A UM DOS

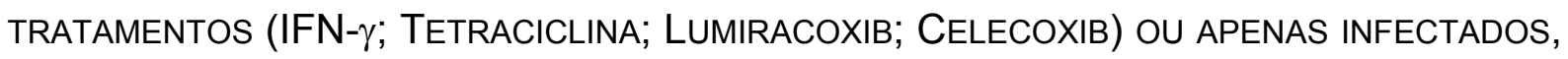
AOS 15 DIAS DE INFECÇÃO.

Figura 7 - Determinação da concentração de NO, mensurado sob a forma de nitrito, em camundongos B10.A inoculados com Pb18 e submetido a um dos tratamentos (IFN- $\gamma$; Tetraciclina; Lumiracoxib) ou apenas infectados, aos 120 dias de infecção..55 Figura 8 - Determinação da concentração de NO, mensurado sob a forma de nitrito, em camundongos B10.A inoculados com Pb18 e submetido a um dos tratamentos (IFN- $\gamma$; Tetraciclina; Lumiracoxib) ou apenas infectados, aos 120 dias de infecção..56 Figura 9 - Concentração das citocinas GM-CSF; TNF- $\alpha$ e IL-12 no epíplon de camundongos B10.A inoculados com Pb18 e submetido a um dos tratamentos (IFN$\gamma$; Tetraciclina; Lumiracoxib; Celecoxib) ou apenas infectados, aos 15 dias de infecção. 
Figura 10 - Concentração das citocinas TGF- $\beta$ e IFN- $\gamma$ no epíplon de camundongos B10.A inoculados com $\mathrm{Pb} 18$ e submetido a um dos tratamentos (IFN- $\gamma$; Tetraciclina; Lumiracoxib; Celecoxib) ou apenas infectados, aos 15 dias de infecção. .58

Figura 11 - Concentração das citocinas GM-CSF; TNF- $\alpha$ e IL-12 no epíplon de camundongos B10.A inoculados com Pb18 e submetido a um dos tratamentos (IFN$\gamma$; Tetraciclina; Lumiracoxib; Celecoxib) ou apenas infectados, aos 120 dias de infecção.

Figura 12 - Concentração das citocinas TGF- $\beta$ e IFN-y no epíplon de camundongos B10.A inoculados com $\mathrm{Pb} 18$ e submetido a um dos tratamentos (IFN- $\gamma$; Tetraciclina; Lumiracoxib; Celecoxib) ou apenas infectados, aos 120 dias de infecção. 60

Figura 13 - Concentração de MMP-9 no epíplon de camundongos B10.A inoculados com $\mathrm{Pb} 18$ e submetido a um dos tratamentos (IFN- $\gamma$; Tetraciclina; Lumiracoxib; Celecoxib) ou apenas infectados, aos 15 (A) e 120 dias (B) de infecção.

Figura 14 - Concentração de MMP-2 no epíplon de camundongos B10.A inoculados com $\mathrm{Pb} 18$ e submetido a um dos tratamentos (IFN- $\gamma$; Tetraciclina; Lumiracoxib; Celecoxib) ou apenas infectados, aos 15 (A) e 120 dias (B) de infecção.

Figura 15 - Determinação do tempo de retenção de hidroxiprolina presente no epíplon de camundongos B10.A. 98

Figura 16 - Concentração de hidroxiprolina presente no epíplon de camundongos B10.A submetido a um dos tratamentos (IFN- $\gamma$; Tetraciclina; Lumiracoxib; Celecoxib) ou apenas infectados, aos 15 dias de infecção. 99

Figura 17 - Concentração de hidroxiprolina presente no epíplon de camundongos B10.A submetido a um dos tratamentos (IFN- $\gamma$; Tetraciclina; Lumiracoxib) ou apenas infectados, aos 120 dias de infecção. 100

Figura 18 - A figura representa uma imagem capturada pelo microscópio Nikon ECLIPSE 80i e feita a contagem quantitativa da imagem capturada pelo programa $\mathrm{NIS} \mathrm{Br}$. 103

Figura 19 - Área da lesão das imagens de epíplon captadas de camundongos B10.A inoculados com Pb18 e submetido a um dos tratamentos (IFN- $\gamma$; Tetraciclina; Lumiracoxib; Celecoxib) ou apenas infectados, aos 15 dias (A) e aos 120 dias (B) de infecção. 104 
Figura 20 - Número de fungos encontrado nas imagens de epíplon captadas de camundongos B10.A inoculados com Pb18 e submetido a um dos tratamentos (IFN$\gamma$; Tetraciclina; Lumiracoxib; Celecoxib) ou apenas infectados, aos 15 dias (A) e aos 120 dias (B) de infecção. 105

Figura 21 - Colágeno Total na lesão das imagens de epíplon captadas de camundongos B10.A inoculados com Pb18 e submetido a um dos tratamentos (IFN$\gamma$; Tetraciclina; Lumiracoxib; Celecoxib) ou apenas infectados, aos 15 dias (A) e aos 120 dias (B) de infecção. 106

Figura 22 - Sobrevida dos camundongos B10.A inoculados com Pb18 e submetido ou não ao tratamento com Tetraciclina do dia 0 ao dia 220 após infecção. 107 


\section{LISTA DE PRANCHAS}

Prancha 1 - Análise quanto à presença de fungos em baço, fígado e pulmão através da coloração Grocott em camundongos apenas infectados, com 15 dias de infecção.

Prancha 2 - Análise quanto à presença de fungos em baço, fígado e pulmão através da coloração Grocott em camundongos infectados e tratados com IFN- $\gamma$ com 15 dias de infecção.

Prancha 3 - Análise quanto à presença de fungos em baço, fígado e pulmão através da coloração Grocott em camundongos infectados e tratados com Tetraciclina com 15 dias de infecção.

Prancha 4 - Análise quanto à presença de fungos em baço, fígado e pulmão através da coloração Grocott em camundongos infectados e tratados com Lumiracoxib com 15 dias de infecção.

Prancha 5 - Análise quanto à presença de fungos em baço, fígado e pulmão através da coloração Grocott em camundongos infectados e tratados com Celecoxib com 15 dias de infecção.

Prancha 6 - Análise quanto à presença de fungos em baço, fígado e pulmão através da coloração Grocott em camundongos apenas infectados, com 120 dias de infecção

Prancha 7 - Análise quanto à presença de fungos em baço, fígado e pulmão através da coloração Grocott em camundongos infectados e tratados com IFN- $\gamma$ com 120 dias de infecção.

Prancha 8 - Análise quanto à presença de fungos em baço, fígado e pulmão através da coloração Grocott em camundongos infectados e tratados com Tetraciclina com 15 dias de infecção.

Prancha 9 - Análise quanto à presença de fungos em baço, fígado e pulmão através da coloração Grocott em camundongos infectados e tratados com Lumiracoxib com 120 dias de infecção. .71

Prancha 10 - Avaliação da disseminação fúngica, aspecto do granuloma e celularidade presente no epíplon através da coloração de Grocott e HE em animais sem infecção 
Prancha 11 - Avaliação da disseminação fúngica, aspecto do granuloma e celularidade presente no epíplon através da coloração de Grocott e HE em animais apenas infectados, aos 15 dias de infecção.

Prancha 12 - Avaliação da disseminação fúngica, aspecto do granuloma e celularidade presente no epíplon através da coloração de Grocott e HE em camundongos infectados e tratados com IFN- $\gamma$, aos 15 dias de infecção. .74

Prancha 13 - Avaliação da disseminação fúngica, aspecto do granuloma e celularidade presente no epíplon através da coloração de Grocott e HE em animais infectados e tratados com Tetraciclina, aos 15 dias de infecção.

Prancha 14 - Avaliação da disseminação fúngica, aspecto do granuloma e celularidade presente no epíplon através da coloração de Grocott e HE em animais infectados e tratados com Lumiracoxib, aos 15 dias de infecção.

Prancha 15 - Avaliação da disseminação fúngica, aspecto do granuloma e celularidade presente no epíplon através da coloração de Grocott e HE em animais infectados e tratados com Celecoxib, aos 15 dias de infecção.

Prancha 16 - Avaliação da disseminação fúngica, aspecto do granuloma e celularidade presente no epíplon através da coloração de Grocott e HE em animais infectados com salina, aos 120 dias de infecção. .78

Prancha 17 - Avaliação da disseminação fúngica, aspecto do granuloma e celularidade presente no epíplon através da coloração de Grocott e HE em animais apenas infectados, aos 120 dias de infecção.

Prancha 18 - Avaliação da disseminação fúngica, aspecto do granuloma e celularidade presente no epíplon através da coloração de Grocott e HE em camundongos infectados e tratados com IFN- $\gamma$, aos 120 dias de infecção. .80

Prancha 19 - Avaliação da disseminação fúngica, aspecto do granuloma e celularidade presente no epíplon através da coloração de Grocott e HE em animais infectados e tratados com Tetraciclina, aos 120 dias de infecção.

Prancha 20 - Avaliação da disseminação fúngica, aspecto do granuloma e celularidade presente no epíplon através da coloração de Grocott e HE em animais infectados e tratados com Lumiracoxib, aos 120 dias de infecção.

Prancha 21 - Análise histológica de pulmões com a coloração HE aos 15 dias de infecção 
Prancha 22 - Análise histológica de pulmões com a coloração HE aos 120 dias de infecção.

Prancha 23 - Análise histológica de fígado com a coloração HE aos 15 dias de infecção.

Prancha 24 - Análise histológica de fígado com a coloração HE aos 120 dias de infecção. .86

Prancha 25 - Análise histológica de baço a coloração HE aos 15 dias de infecção.

Prancha 26 - Análise histológica de baço a coloração HE aos 120 dias de infecção.

Prancha 27 - Análise das fibras colágenas no epíplon dos animais apenas infectados, aos 15 dias de infecção, corado com Picrosirius.

Prancha 28 - Análise das fibras colágenas no epíplon dos animais infectados e tratados com IFN- $\gamma$, aos 15 dias de infecção, corado com Picrosirius. .90

Prancha 29 - Análise das fibras colágenas no epíplon dos animais infectados e tratados com Tetraciclina, aos 15 dias de infecção, corado com Picrosirius.

Prancha 30 - Análise das fibras colágenas no epíplon dos animais infectados e tratados com Lumiracoxib, aos 15 dias de infecção, corado com Picrosirius.

Prancha 31 - Análise das fibras colágenas no epíplon dos animais infectados e tratados com Celecoxib, aos 15 dias de infecção, corado com Picrosirius .93

Prancha 32 - Análise das fibras colágenas no epíplon dos animais apenas infectados, aos 120 dias de infecção, corado com Picrosirius.

Prancha 33 - Análise das fibras colágenas no epíplon dos animais infectados e tratados com IFN- $\gamma$, aos 120 dias de infecção, corado com Picrosirius. .95

Prancha 34 - Análise das fibras colágenas no epíplon dos animais infectados e tratados com Tetraciclina, aos 120 dias de infecção, corado com Picrosirius. .96

Prancha 35 - Análise das fibras colágenas no epíplon dos animais infectados e tratados com Lumiracoxib, aos 120 dias de infecção, corado com Picrosirius.

Prancha 36 - Reação de estreptavidina-peroxidade para detecção de colágeno I aos 15 dias de infecção. 101

Prancha 37 - Reação de estreptavidina-peroxidade para detecção de colágeno I aos 120 dias de infecção 102 


\section{SUMÁRIO}

1 INTRUDUÇÃO

2 OBJETIVOS

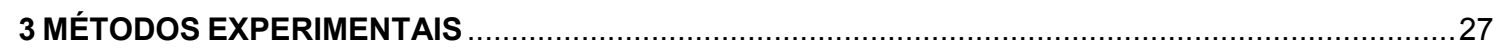

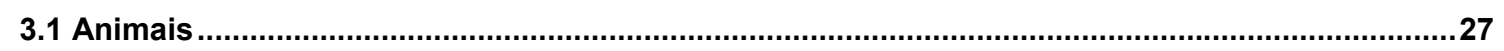

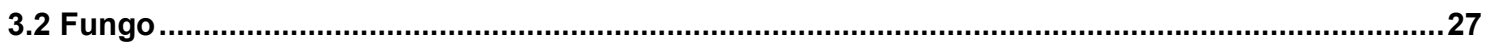

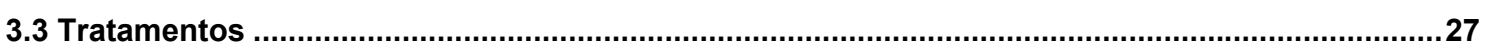

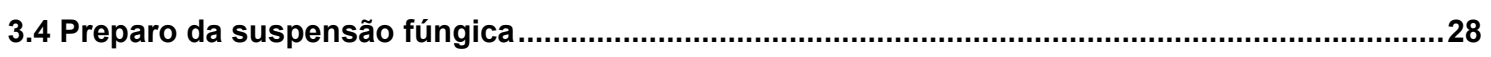

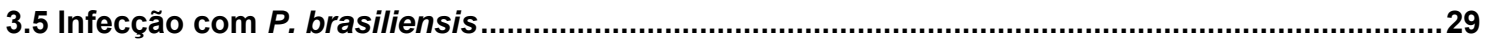

3.6 Coleta de órgãos para avaliação das lesões granulomatosas e presença de fungos viáveis ...29

3.7 Quantificação de $P$. brasiliensis viáveis ...................................................................................29

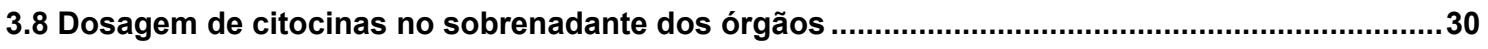

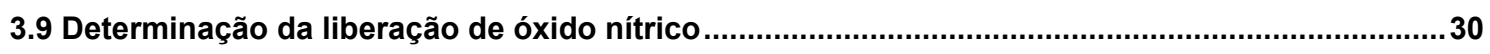

3.10 Preparo dos órgãos para análises histológicas e imunohistoquímicas ........................................

3.11 Análises histológicas ............................................................................................................

3.12 Captura de imagens para as análises histológica e imunohistoquímica...................................31

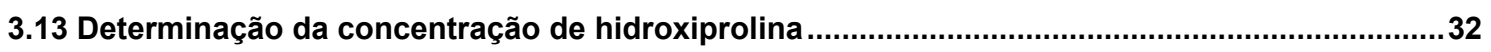

3.14 Análise imuno-histoquímica através da reação de estreptavidina-biotina-peroxidase ................32

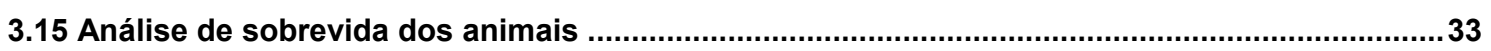

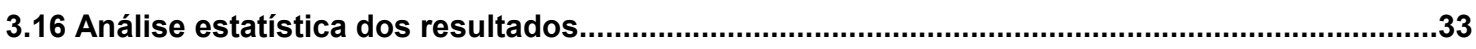

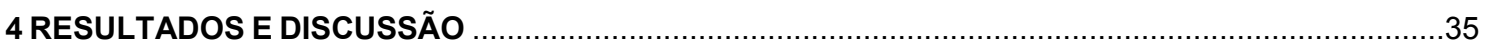

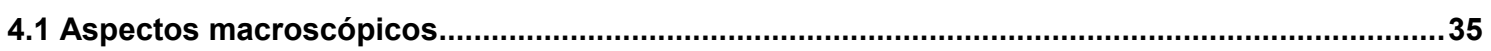

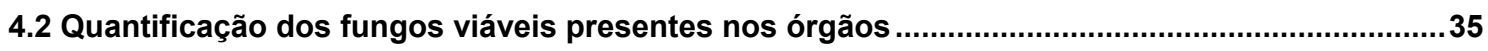

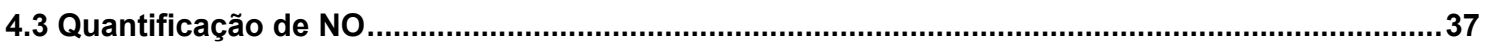

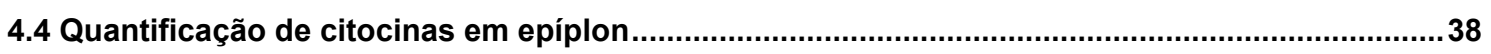

4.5 Quantificação de metaloproteinases no epíplon .......................................................................40

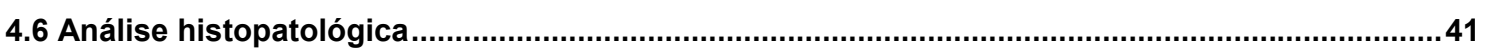

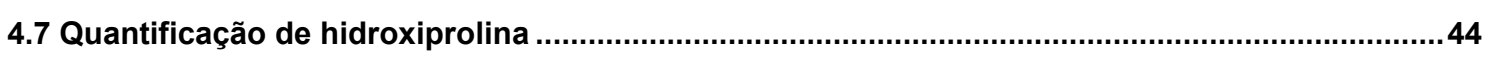

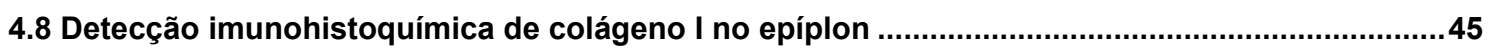

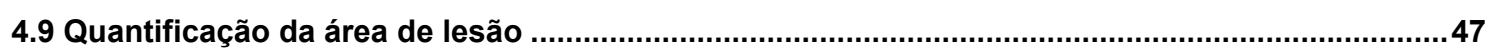

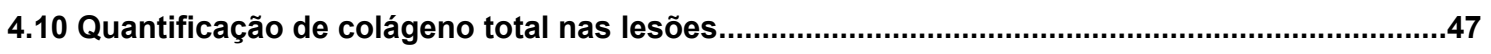

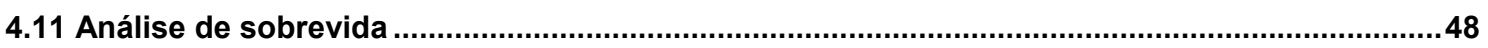

5 CONCLUSÕES

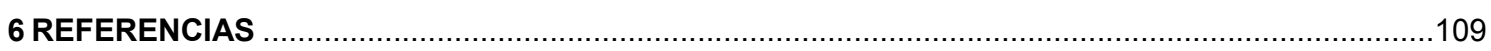




\section{INTRODUÇÃO}

A paracoccidioidomicose é uma doença sistêmica com prevalência na América Latina, causada pelo fungo termo-dimórfico P.brasiliensis. O fungo é encontrado em forma infectante de micélio na temperatura ambiente, e no corpo ganha a forma patogênica de levedura. A doença ocorre principalmente em homens, cujas infecções provavelmente começam pela inalação do propágulo do fungo, e a doença se instala nos pulmões e em seguida pode disseminar através da circulação sanguínea e / ou vias linfáticas para outros tecidos. A disseminação da doença pode atingir vários órgãos, como fígado, baço, glândulas supra-renais, pele e mucosas, entre outros, onde ele induz lesões graves e permanece viável mesmo após o tratamento com antimicóticos. (ACORCl et al., 2008; KONNO et al., 2009)

Após o contato primário do hospedeiro com o fungo, a PCM manifesta-se sob diferentes formas clínicas, podendo apresentar a forma aguda da doença, ou a forma crônica. A forma benigna é caracterizada pelo desenvolvimento de uma eficiente resposta imune celular frente ao $P$. brasiliensis, baixa imunidade humoral, ativação eficiente de fagócitos e de citocinas associadas a resposta $T$ helper 1 , com posterior controle desta doença; já a forma grave é caracterizada pela presença de hipergamaglobulunemia com altos títulos de anticorpos anti- $P$. brasiliensis e baixa resposta celular, com uma reduzida ativação de fagócitos e alta produção de citocinas preferencialmente do tipo $\mathrm{T}$ helper 2 , que evolui para um quadro de disseminação fúngica (MUSATTI et al., 1976; BIAGIONI et al., 1984).

Estudos com modelo murino de infecção com o isolado altamente virulento do fungo $P$. brasiliensis pela via intraperitoneal (ip) comparando a sobrevida dos camundongos de diferentes linhagens após infecção, associando o padrão genético dos animais, permitiram caracterizar a linhagem $\mathrm{A} / \mathrm{J}$ como resistente à $\mathrm{PCM}$ e a linhagem B10.A como susceptível (CALICH et al., 1985). Após esse estudo, essa classificação tem sido amplamente utilizada em estudos da PCM experimental. $\mathrm{Na}$ infecção pela via ip, o fungo se instala no omento, que acaba sendo um órgão alvo com marcante recuperação de fungos viáveis (SINGER-VERMES et al., 1993). O omento é formado por camadas de tecido mesotelial contendo tecido cunjuntivo frouxo, células adiposas e agregados de leucócitos. Esses agregados leucocitário 
atuam como importante fonte de macrófagos e um dos principais tecidos imunes da cavidade peritoneal (LENZI et al., 1996; PLATELL et al., 2000).

A PCM é caracterizada por ser uma doença granulomatosa; a formação do granuloma pode ser compreendida como um mecanismo do organismo para bloquear e circunscrever o fungo ou seus componentes antigênicos, uma vez impossibilitado de lisá-los. As formas benignas da doença são caracterizadas por uma infecção localizada, contendo granulomas compactos com poucos fungos; já nas formas mais graves, ocorre um processo granulomatoso frouxo com focos de necrose e intensa disseminação fúngica (FRANCO et al., 1998).

Granulomas são estruturas compostas por diferentes tipos celulares, em meio a uma mistura de citocinas e fatores de crescimento, preenchidas por diversas moléculas constituintes da matriz extracelular (MEC), tais como colágenos, glicoproteínas, proteoglicanas e enzimas proteolíticas. Estes componentes possuem propriedades adesivas e apresentam estruturas complexas, agindo como um reservatório de mediadores inflamatórios, tais como citocinas e quimiocinas, acionando a regulação das células envolvidas na imunidade inata e adquirida, a fim de manter a integridade tecidual durante os diferentes processos que ocorrem em virtude de uma infecção, ajudando na restituição dos tecidos e sua posterior cicatrização (VADAY et al., 2001). Algumas citocinas desempenham papéis importantes "in situ" no granuloma. O fator de necrose tumoral (TNF- $\alpha$ ) tem importante papel no início da formação do granuloma (SOUTO et al., 2000), exercendo efeito inibitório sobre o gene e na síntese da proteína de colágeno (GHOSH, 2002). Alem disso, estudos mostraram que animais deficientes desta citocina tinham a formação descontrolada de granuloma (TAFLIN et al., 2009).

O interferon-y (IFN-y), produzido por linfócitos $T$ e células Natural Killers (NK) ativadas, entre outras células, possui função de extrema relevância nos mecanismos de defesa de vários patógenos. Quando o IFN faz a ativação de macrófagos, ocorre indução do complexo enzimático dinuclaotídeo nicotinamida-adenina-fosfato oxidase (NADPH oxidase), regulação positiva de enzimas lisossomais e a estimulação de reativos intermediários de nitrogênio como o óxido nítrico (NO). O IFN possui ação anti-fibrótica, através da inibição da síntese de colágeno e do aumento da degradação de colágeno tipo I e III (GHOSH, 2002) de sua ação anti-fungica, que 
parece estar associada a presença de TNF- $\alpha$ (SOUTO et al., 2000) e IL-12 (HARRING, 2002) além desta citocina induz a expressão de um substrato necessário para a produção de NO.

O fator de crescimento tumoral (TGF- $\beta$ ) exerce efeitos pró-fibróticos através da indução de componentes da MEC (SIME et al., 1997) é indutor de fibrogênese em diferentes infecções granulomatosas, através da ativação de fibroblastos, levando à produção de colágeno e promovendo a formação do granuloma (WYNN et al., 2004). Um dos fatores é que está citocina está relacionada para que isso ocorra, é a transativação de genes múltiplos com o PAI-I. PAI-1 é o principal inibidor do sistema fibrinolítico e é necessário para a degradação de componentes adequada ECM. Alteração da expressão de PAl-1, por conseguinte, perturba o equilíbrio ECM (NIEMANTSVERDRJET et al., 2010)

O balanço entre a síntese a degradação de componentes da MEC nas lesões granulomatosas pode ser influenciado pela participação de enzimas proteolíticas, em especial pelas metaloproteases (MMPs). As MMPs são membros de uma família de enzimas zinco-dependentes, secretadas na forma latente, que apresentam um domínio estrutural comum e são produzidas por diversas populações celulares, como os fibroblastos, as células epiteliais e os leucócitos (NISHIKAKU et al., 2009). A expressão de MMPs é regulada a nível de transcrição gênica, na ativação da próenzima e por inibidores endógenos como os inibidores teciduais das metaloproteases da matriz (TIMPs). As MMPs são enzimas com ação de colagenases intersticiais (MMP-1), gelatinases ou colagenases tipo IV (MMP-2 e MMP-9), estromelisinas (MMP-3 e MMP10) colagenases de neutrófilos (MMP-8), matrilisina (MMP-7), metaloelastase (MMP-12) e MMPs do tipo membrana (membrane-type MMPs - MT-MMPs) (BARRICK; CAMBELL; OWEN, 1999). Essas proteinases possuem atividade biológica bastante variada, incluindo participação em processos fisiológicos e patológicos afetando mecanismos como a coagulação e fibrinólise, adesão, quimiotaxia e migração celular, atividade microbicida e remoção de debris teciduais, modulação da resposta imune e inflamatória, ativação ou inibição de fatores de crescimento e citocinas, além de estarem envolvidas no reparo e cicatrização tecidual em diversas doenças. O efeito do IFN-Y sobre colágeno acaba por modular a expressão das MMPs (TAMAl et al., 1995), de forma oposta à 
ação do TGF- $\beta$ o qual modula positivamente a expressão das MMPs (QUAN et al., 2006).

A participação dos componentes da MEC em diversas patologias infecciosas ou parasitárias tem sido objeto de estudo. Em modelo experimental de PCM, relatouse a detecção de proteínas intersticiais de colágeno I e III em resposta granulomatosa, direcionando o padrão das respostas teciduais à infecção pelo $P$. brasiliensis. No estágio mais tardio da doença, foi detectada a presença de grande quantidade de colágenos fibrilares e reticulares e culminando em produção de fibrose (KERR; OLIVEIRA; LENZI, 1988). A deposição de colágenos tipo I, III e IV, fibronectina, laminina, proteoglicanas e elastina foi observada em estudos da infecção experimental com $P$. brasiliensis, nas quais camundongos resistentes apresentavam deposição de colágeno tipo I em lesões bem delimitadas, e os animais susceptíveis apresentavam deposição de colágeno tipo III em uma lesão mais frouxa e com disseminação fúngica. Também se verificou que alterações na estrutura e morfologia dos órgãos eram associadas com formação de granulomas acompanhadas por necrose e fibrose dos tecido, diversidade de populações celulares, presença de citocinas pró e anti-inflamatórias e a de componentes da MEC (NISHIKAKU; BURGER, 2003).

A fibrose é uma seqüela freqüente e incapacitante de numerosas infecções entre elas a PCM, tendo como característica a proliferação de fibroblastos e depósito de MEC. Apesar de terapias efetivas estarem disponíveis para o controle do processo infeccioso, a maioria dos pacientes com PCM desenvolve seqüelas fibróticas que causam alterações patológicas ao parênquima dos órgãos e interferem com as funções respiratórias, comprometendo seu bem-estar pelo resto da vida (BRUMMER et al., 1993). É sabido que a fibrose é reversível e conseguir prevenir a sua progressão ou revertê-la nos pacientes de PCM é de grande importância. Assim, o emprego de drogas que modulam a matriz extracelular, afetando sua síntese e degradação é um tema que apresenta um interesse, tanto de ordem acadêmica como de ordem prática e que ainda carece de informações.

Uma das drogas que tem este efeito modulador é a citocina IFN- $\mathrm{y}$, cujos efeitos antifibróticos vem sendo relatados, (SANCÉAU et al., 2002) demonstraram que a administração dessa citocina inibe a ativação de MMP-9, por diminuir nas 
mesmas, receptores para TNF- $\alpha$, a qual por sua vez, ativa essa metaloprotease. Outros estudos mostram que o IFN-y também possui capacidade fungicida para $P$. brasiliensis, ativando macrófagos (KASHINO et al., 2000) e potencializando o efeito fungicida de neutrófilos (KURITA et al., 1999). O emprego dessa citocina como terapia auxiliar na PCM é tema promissor de investigação, pois além de eliminar os fungos viáveis, modula a fibrose.

Os efeitos do antibiótico tetraciclina em relação à modulação da MEC também vem sendo estudados, porém a literatura é carente de dados em relação a estes efeitos em infecções fúngicas. A capacidade dessa droga em inibir as MMPs, foi verificada por HUREWITZ et al (1993) que observaram uma redução de $75 \%$ das MMPs de liquido pleural em humanos e inibição celular de MMPs em uma dose mais concentrada. PAIXÃO-CAVALCANTE et al. (2007) demonstraram que a terapia com tetraciclina reduz a expressão de MMP-2 e impede a indução de MMP-9 diminuindo as lesões cutâneas pelo veneno da aranha do gênero Lexosceles.

Outro alvo de estudos em relação aos componentes da MEC, e em específico das MMPs, são os antiinflamatórios inibidores específicos da enzima ciclooxigenase COX. Estudos mostram a existência de duas enzimas COX. A COX-1, presente em quantidades relativamente constantes nas diferentes células e tecidos cujo gene tem as características de um gene constitutivo ou "housekeeping". Já a COX-2 está normalmente ausente, ou presente em pequenas quantidades em células não proliferativas e seu gene tem as características de um gene indutível, ou seja, sua expressão é muito aumentada quando as células são estimuladas por citocinas ou mitógenos (PARK et al., 2007).

O efeito de inibidores específicos de COX em camundongos infectados com $P$. brasiliensis foi estudado empregando modelo de bolsa sub-cutânea (bsc) anteriormente descrito (MELONI-BRUNERI et al., 1996). Os resultados revelaram que inibição farmacológica da COX empregando a droga celecoxib acarreta um aumento do número de neutrófilos; a inibição exclusiva da COX-2 com a droga lumiracoxib, além de levar ao aumento do número de neutrófilos, aumenta sua capacidade fungicida. Os animais tratados tiveram um aumento significante da citocina GM-CSF, eventualmente responsável pelo recrutamento celular (MOLINA et al., 2007). Recentes estudos mostraram que os inibidores específicos de COX-2 
atuam na regulação negativa das MMP-2, além da expressão de pro-MMP-2 ativa (KURIHARA et al., 2009). Com relação às drogas propostas por nosso estudo, existem trabalhos sobre o efeito da droga celecoxib na MEC que relataram resultados contraditórios. Em um estudo com condrócitos humanos, foi constatado que o celecoxib não apresentou efeito sobre MMPs (NAKAMURA et al., 2007), porém outro trabalho relatou uma diminuição da expressão das mesmas (LARKINS et al., 2006). Estudos sobre o efeito de lumiracoxib sobre a MEC não foram ainda descritos.

A gravidade da fibrose como seqüela do PCM, a possibilidade de interferir neste processo, através do efeito de algumas drogas, e a disponibilidade de um modelo experimental de PCM bem caracterizado, nos levaram ao planejamento do presente estudo. 


\section{OBJETIVOS}

Este trabalho tem por objetivo analisar o efeito de algumas terapias que afetam o equilíbrio na síntese e degradação da MEC em lesões granulomatosas na paracoccidioidomicose experimental murina.

Aferiremos o efeito do tratamento com os compostos IFN- $\mathrm{y}$, tetraciclina, celecoxib e lumiracoxib através da análise histológica e histoquímica dos granulomas, avaliando a arquitetura dos mesmos, a composição do infiltrado celular inflamatório, a presença de fungos íntegros ou destruídos, de fibras colágenas e de seus produtos de degradação, a expressão local de citocinas e de componentes da MEC. 


\section{MÉTODOS EXPERIMENTAIS}

\subsection{Animais}

Utilizamos camundongos isogênicos, da linhagem suscetível a paracoccidioidomicose B10.A (CALICH et al., 1985), do sexo feminino, com idade de 6 a 7 semanas, adquiridos do Biotério do Departamento de Imunologia do Instituto de Ciências Biomédicas, da Universidade de São Paulo. Cinco animais foram mantidos em cada gaiola do tipo microisolador, à temperatura de $22{ }^{\circ} \mathrm{C}$, com iluminação variando de 12 em 12 horas, recebendo ração Nuvital, e água acidificada ad libitum.

\subsection{Fungo}

Empregamos o isolado altamente virulento $\mathrm{Pb} 18$ (KASHINO et al., 1985) de $P$. brasiliensis. Esse isolado foi mantido em sua fase leveduriforme por meio de repiques semanais em meio Fava-Netto a $35-37^{\circ} \mathrm{C}$, e com controle da manutenção de sua virulência conforme descrito anteriormente (KASHINO et al., 1990).

\subsection{Tratamentos}

Interferon-y: Inoculamos a citocina recombinante IFN-y (Genentech, Inc., South San Francisco, CA) pela via ip, nos dias $-7 ;-5 ;-3$ e -1 nos animais infectados durante 15 dias e nos dias 120; 118; 116; 114; -7; -5; -3 e -1 nos animais infectados por 120 dias, considerando como dia zero, o dia da infecção com $P$. brasiliensis em ambos os períodos de infecção. Empregamos a dose de 100.000U, dose essa comprovadamente eficaz atividade anti-fibrótica (CLEMONS; LUTZ; STEVENS, 2001).

Tetraciclina: Usamos o antibiótico Tetraciclina por via oral, em duas tomadas diárias. O tratamento se deu todos os dias, a partir do dia -7 da infecção nos animais infectados por 15 dias, e por uma semana a partir do dia 116 e por mais sete dias a partir do dia -7 de infecção com $P$. brasiliensis em ambos os períodos de infecção, na dose de 40mg/kg/dia, dose já comprovada como eficaz para inibir MMPs (PALLASCH, 2004). 
Celecoxib: Utilizamos a droga anti-inflamatória Celecoxib (Celebra®), dividida em duas tomadas diárias por via oral a cada 12 horas, por três dias, sendo a primeira no dia $11^{\circ}$ dia de infecção nos animais que serão analisados aos 15 dias de infecção com $P$. brasiliensis, sendo a ultima tomada sempre três horas antes das coletas. A dose administrada aos camundongos foi de $6 \mathrm{mg} / \mathrm{kg} / \mathrm{dia}$, dose essa comprovadamente eficaz em inibir a enzima inflamatória COX, com efeito, antiMMPs (SCIULLI et al., 2005). A droga Celecoxib foi empregada apenas no período inicial de infecção (15 dias) por apresentar os mesmo resultados que o outro antiinflamatório empregado Lumiracoxib.

Lumiracoxib: Empregamos a droga lumiracoxib (Prexige ${ }^{\circledR}$ ), administrada por via oral, em apenas uma tomada diária. O esquema terapêutico durou três dias, sendo a primeira tomada no $11^{\circ}$ dia de infecção nos animais a serem analisados com 15 dias de infecção com $P$. brasiliensis e seis dias, sendo o começo do tratamento semelhante aos animais com 15 dias de infecção e receberam administração nos $118^{\circ}$ ao $120^{\circ}$ dia de infecção, sendo a ultima dose sempre três horas antes da coleta da infecção. A dose empregada foi de $7 \mathrm{mg} / \mathrm{kg} / \mathrm{dia}$, dose essa eficaz em inibir especificamente a enzima COX-2 (SCIULLI et al., 2005) e cujos efeitos sobre MMPs ainda não foros descritos.

Controles: Todos os grupos possuíram seus respectivos grupos controle, que receberam água destilada autoclavada sendo o mesmo esquema terapêutico de cada uma das drogas.

\subsection{Preparo da suspensão fúngica}

O crescimento fúngico foi recolhido esterilmente dos tubos de repiques após 7 dias; as células foram lavadas três vezes com PBS pH 7.2 e contadas em câmara hemocitométrica de Neubauer, sendo a concentração ajustada segundo o experimento. A viabilidade fúngica foi observada pela coloração com Janus Green (BERLINER; RECA, 1966), sendo aceitas preparações com viabilidade fúngica superior ou igual a $80 \%$. 


\subsection{Infecção com P. brasiliensis}

Em cada experimento foram usados grupos de cinco camundongos para cada tratamento e para o grupo controle, e foram inoculados pela via ip com $5 \times 10^{6}$ células leveduriformes em um volume de $0,5 \mathrm{ml}$ para coleta das amostras após 15 e 120 dias de infecção.

\subsection{Coleta de órgãos para avaliação das lesões granulomatosas e presença de fungos viáveis}

Coletamos para análise aos 15 após infecção ip o omento, baço, fígado e pulmões de cada animal após sua anestesia com $20 \mathrm{mg} / \mathrm{kg}$ da associação tiletaminazolazepam (Zoletil ${ }^{\circledR}$ ) pela via intramuscular (FANTONI; CORTOPASSI, 1996) e seu posterior sacrifício. Estes procedimentos foram realizados segundo as normas preconizadas pelo Comitê de Ética para Experimentação Animal da Universidade de São Paulo. Os órgãos foram coletados e pesados; parte foi utilizada para avaliarmos o número de células fúngicas viáveis através de ensaios de unidades formadoras de colônias (CFU) e concentração de citocinas e hidroxiprolina; o restante foi empregado para as análises histológicas e imunohistoquímicas.

\subsection{Quantificação de P. brasiliensis viáveis}

Para a quantificação do número de P.brasiliensis viáveis utilizamos a técnica de contagem de unidades formadoras de colônias (CFU). O material obtido dos órgãos foi homogeneizado em $5 \mathrm{ml}$ após serem macerados em potters. O homogenato foi centrifugado a 3000rpm por 5 minutos. O sedimento foi ressuspenso em $1 \mathrm{ml}$ de PBS e semeado em meio $\mathrm{BHI}$ enriquecido. As placas foram incubadas a $37{ }^{\circ} \mathrm{C}$ e o crescimento das colônias foi acompanhado por um período entre 13 e 15 dias, sendo o resultado expresso em log UFC/grama de tecido (SINGER-VERMES et al., 1992). 


\subsection{Dosagem de citocinas no sobrenadante dos órgãos}

As concentrações das citocinas foram determinadas por testes de ELISA, utilizando anticorpos monoclonais em pares específicos para cada citocina, um deles marcado com biotina. Para a detecção de TNF- $\alpha$, IL-12, MMP-2 e MMP-9 foram utilizados ELISA Development Kits (Peprotech, Ciudad de México, México), enquanto IFN-Y, TGF- $\beta$ e GM-CSF foram tituladas empregando reagentes fabricados por BD Pharmingen (San Diego, USA). Com o complexo biotina-avidina e $\mathrm{H}_{2} \mathrm{O}_{2}$-peroxidase foi possível dosar a concentração de citocinas por densidade óptica (COLIGAN et al., 1991). Placas com fundo chato de 96 wells foram sensibilizadas com anticorpo primário ou de captura nas concentrações determinadas pelo fabricante. Passadas 24 horas fizemos o bloqueio dos sítios livres e após duas horas foram adicionadas, a respectiva citocina recombinante. Após 18 horas aproximadamente, foi adicionado o anticorpo secundário diluído em PBS com 10\% de SFB e após incubação à temperatura ambiente por 45 minutos, foi acrescido o conjugado estreptavidinaperoxidase diluído em PBS com gelatina. Feito isso, a placa foi incubada por uma hora à temperatura de $37^{\circ} \mathrm{C}$. Após esse período, foi feita uma reação com OPD (ortofenilenidiamina) em tampão fosfato $0,2 \mathrm{M}$, ácido cítrico $0,1 \mathrm{M} \mathrm{pH} 5.0$ e água destilada com $\mathrm{H}_{2} \mathrm{O}_{2}$ imediatamente antes do uso. A reação, por ser fotossensível, foi incubada ao abrigo de luz por 45 minutos. A parte final deste ensaio se deu pela adição de ácido sulfúrico $\left(\mathrm{H}_{2} \mathrm{SO}_{4}\right) 4 \mathrm{~N}$. A leitura foi feita em leitor óptico de ELISA em comprimento de onde de 492nm (Labsystem Multskan EX).

\subsection{Determinação da liberação de óxido nítrico}

Neste ensaio, $50 \mu \mathrm{L}$ de reagente de Griess (solução aquosa contendo sulfonilamida a $1 \%, N, N, N^{\prime}, N$ '-tetrametiletilenediamina [NEED] a $0,1 \%$ e ácido fosfórico a 2,5\% [reagentes produzidos por Sigma; números de catálogo, respectivamente, S-9251, N-5889 e P-6560]) foram adicionados ao mesmo volume de sobrenadantes de órgão ou de cultivo celular obtidos conforme descrito anteriormente. Os ensaios foram realizados em duplicata e, após incubação por 10 minutos à temperatura ambiente, a leitura das densidades ópticas foi realizada em microleitor de ELISA (Multiskan EX, Labsystems, Fischer, Pittsburgh, USA), em comprimento de onda de 540nm. Os resultados foram expressos em micromoles de nitrito por grama de tecido, 
comparando-se a densidade óptica obtida com uma curva-padrão contendo concentrações conhecidas de nitrito de sódio (Sigma, 251-4) (DING et al., 1990).

\subsection{Preparo dos órgãos para análises histológicas e imunohistoquímicas}

Os órgãos coletados foram fixados em solução de Methacarn (60\% de metanol, $30 \%$ de clorofórmio e $10 \%$ de ácido acético glacial), durante quatro horas, sob agitação, a $4^{\circ} \mathrm{C}$ e em seguida estendida em papel-cartão, para permitir uma fixação mais homogênea. Os materiais fixados foram colocados em álcool absoluto por 24 horas, submetidos a mais três passagens em álcool por 30 minutos cada, seguido por passagem em xilol (três vezes, 15 minutos cada) e por final foram embebidos em parafina (três vezes, 15 minutos cada) e montados em blocos, para posterior realização de cortes de $5 \mu \mathrm{m}$ de espessura para avaliação histológica.

\subsection{Análises histológicas}

Os órgãos de cada um dos camundongos foram corados pelas técnicas empregando corantes hematoxilina e eosina (HE), para observação da arquitetura dos cortes histológicos e para identificação da celularidade presente nos órgãos; impregnação pela prata metanamina (GROCOTT, 1955), para identificação da presença e morfologia de fungos nos órgãos; Picrosirius, para identificação das fibras colágenas presentes nos órgãos através de microscopia óptica com polarização de luz (JUNQUEIRA; BIGNOLAS; BRENTANI, 1979). As lâminas foram montadas em solução Permout e observadas em microscópio óptico (Hund Wetzlar) com aumentos totais de 40x, 100x, 250x e 400x.

\subsection{Captura de imagens para as análises histológica e imunohistoquímica}

A expressão de colágeno tipo I por reação de imunohistoquímica, bem como as análises histológicas e quantitativas das lesões foram feitos a partir da captura de imagens, empregando-se o microscópio óptico Eclipse 80i (Nikon, Japan) acoplado a uma câmera digital (DS-Fi1, Nikon Co., Japan) e programa de captura e análise NIS-Br versão 2.34 (Nikon, Japan). 


\subsection{Determinação da concentração de hidroxiprolina}

Para esta dosagem foi necessário inicialmente desproteinizar a amostra; para tanto adicionamos à amostra etanol $90 \%$, agitaremos por 10 minutos e centrifugaremos a $3000 x g$ por 5 minutos. Coletamos o sobrenadante e procedemos à evaporação da amostra em aparelho SpeedVac $\left(60^{\circ} \mathrm{C}\right)$. A seguir reconstituimos a amostra em 250ul de água Milli-Q filtrada e transferimos a amostra para um recipiente ao abrigo de luz com 50ul de OPA (o-phtaldialdeído); agitamos vigorosamente e deixamos a temperatura ambiente por 5 minutos. Como a hidroxiprolina é um aminoácido secundário, foi necessário fazer a remoção dos aminoácidos primários através de cromatografia e coluna apolar (Adsorbex ${ }^{\circledR}$ RP-18 400mg) (Merck) ativadas com metanol e equilibradas com o tampão de eluição EB (Acetato de Sódio, acetonitrila, com $\mathrm{pH}$ ajustado para $6.4 \mathrm{com}$ ácido clorídrico). Em seguida o eluato sofre uma derivatisação com fenilisotiocianato. Finalmente a quantificação da hidroxiprolina foi realizada através de cromatografia liquida de alta performance de fase reversa (RPHPLC) utilizando equipamento HPLC Prominience (Shimadzu Corp, Kyoto, Japan) com bomba LC029AT e detector SPD-M20A, empregando uma coluna C18 (Waters) e lida comprimento de onda a 254nm (LANGE; MÁLYUSZ, 1994).

\subsection{Análise imuno-histoquímica através da reação de estreptavidina-biotina-} peroxidase

A análise imuno-histoquímica foi utilizada para avaliar a expressão de colágeno tipo I em omento. A reação de estreptavidina-biotina-peroxidase foi empregada seguindo a metodologia preconizada por SOTO-SUAZO et al. (2002) e conforme descrita em trabalho anterior por NISHIKAKU (2003). Resumidamente, os cortes histológicos foram desparafinizados e reidratados com banhos sucessivos de xilol, álcool e água destilada. Após lavagem das lâminas com PBS ( $\mathrm{pH} 7,2-7,4)$, fez-se o bloqueio de peroxidases endógenas com solução $3 \%$ de peróxido de hidrogênio $(30 \%)$ em PBS sob agitação, por 30 minutos. Em seguida, soros normais de animais da espécie produtora do anticorpo secundário na diluição 1:1 em PBS/ABS (albumina bovina sérica) $10 \%$ foram aplicados sobre os cortes para o bloqueio de reações 
inespecíficas. Além disso, empregou-se uma solução tampão TBS (Tris-buffered saline - salina tamponada com Tris) (Pierce Inc.) sobre os cortes de tecido para o bloqueio de biotina endógena. As lâminas foram incubadas com os anticorpos primários específicos para colágeno tipo I (1:800, antissoro policlonal de coelho anticolágeno humano, LF-123, $1 \mathrm{mg} / \mathrm{mL}$, Fisher et al. (1995) "overnight" a $4{ }^{\circ} \mathrm{C}$, nas diluições adequadas em PBS/Tween 20 0,3\% e depois incubadas com o anticorpo secundário biotinilado (Rockland Inc.), diluído 1:500 em PBS, por uma hora a temperatura ambiente. A seguir, as lâminas foram incubadas com estreptavidinaperoxidase (1 mg/mL, Vector Laboratories) na diluição 1:100 em PBS por uma hora a temperatura ambiente e a reação revelada com tetra-hidrocloreto de 3,3' diaminobenzidina (Sigma Biochemical Co.) e adição de peróxido de hidrogênio 30\%. As reações foram interrompidas após a visualização de cor marrom nos cortes de tecidos e a seguir, as lâminas foram contracoradas com Hematoxilina de Mayer, desidratadas e montadas em solução Permount e observadas em microscópio óptico (Hund Wetzlar) com aumentos totais de 40x, 100x, 250x e 400x.

Lâminas de cortes de tecido (omento) controles de anticorpo primário (substituído pelo diluente) foram empregadas para avaliar a especificidade da reação.

\subsection{Análise de sobrevida dos animais}

Os animais submetidos ao teste de sobrevida foram inoculados com o isolado altamente virulento de P.brasiliensis pela via intraperitoneal e deixados no Biotério de Experimentação Animal. As caixas foram chegadas a cada vinte dias para visualização de quantos animais ainda permanecia vivo. A contagem foi finalizada no dia 200 a partir da infecção. No grupo de animais que receberam tratamento, o esquema terapêutico de deu da mesma maneira que os animas tratados sacrificados aos 120 dias de infecção.

\subsection{Análise estatística dos resultados}

Os resultados foram submetidos à análise de variância, seguida por comparações múltiplas pelo método de Tukey-Kramer ou testes $t$ não pareados, de acordo com o 
número de grupos experimentais comparados (ZAR, 1984). Todas as análises foram feitas em software GraphPad Prism 4 for Windows (GraphPad Softwares, 2003). O $n$ utilizado foi igual ou superior a dez animais B10.A; o valor de $p$ adotado para o nível de significância foi de, pelo menos, menor que 0,05. 


\section{RESULTADOS E DISCUSSÃO}

\subsection{Aspectos macroscópicos}

A observação macroscópica dos órgãos coletados dos animais aos 15 dias de infecção permitiu verificar que os camundongos tratados com alguma das drogas antiinflamatórias apresentavam um aumento do tamanho dos órgãos que chegava a ser de $100 \%$ sobre os respectivos órgãos dos animais apenas infectados. Estes, por sua vez apresentavam os mesmo órgãos maiores em relação ao grupo de animais que receberam tratamento com IFN- $\gamma$ ou Tetraciclina. Proporcional ao tamanho dos órgãos, eram os números de lesões vistas a olho nu nos órgãos, quando coletados para as demais análises.

Aos 120 dias de infecção, os animais tratados com IFN-y apresentaram os órgãos com o mesmo tamanho dos animais que foram infectados com salina, já os animais tratados com lumiracoxib ou com tetraciclina apresentaram um aumento do tamanho do baço, fígado e epiplon, com tamanho semelhante aos animais apenas infectados

\subsection{Quantificação dos fungos viáveis presentes nos órgãos}

Analisando os números de $P$. brasiliensis viáveis recuperados no período de 15 dias de infecção, verificamos que no pulmão (Figura 1A) o grupo tratado com IFN- $\gamma$, com Tetraciclina e os animais apenas infectados tiveram uma diminuição significativa de fungos viáveis em relação aos animais tratados com Lumiracoxib ou Celecoxib. A Tetraciclina foi o tratamento que levou ao menor número de fungos viáveis, porém não de forma significativa em relação ao tratamento com IFN- $\gamma$ ou aos animais apenas infectados. No epíplon (Figura 1B) os animais que receberam tratamento com IFN- $\gamma$ ou com Tetraciclina apresentaram uma diminuição significativa de fungos viáveis em relação aos animais apenas infectados e em relação ao grupo tratado com Lumiracoxib ou Celecoxib. Analisando o fígado (Figura 2A) observamos os mesmos resultados obtidos no epíplon, ou seja, os animais que receberam tratamento com IFN- $\gamma$ ou com Tetraciclina mostraram uma diminuição de fungos viáveis presentes nesse órgão em relação aos grupos de animais apenas infectados e em relação aos tratados com Lumiracoxib ou com Celecoxib. No baço (Figura 2B) 
os valores encontrados mostraram que os animais tratados com IFN- $\gamma$, Tetraciclina, ou apenas infectados, tiveram um número significativamente menor de fungos viáveis presentes nesse órgão em relação aos animais que receberam tratamento com Lumiracoxib ou Celecoxib.

Aos 120 dias de infecção, pudemos verificar que no pulmão (Figura 3A) os animais que receberam tratamento com IFN- $\gamma$, ou com o antibiótico Tetraciclina apresentaram um número significantemente menor de fungos viáveis em relação aos animais apenas infectados, em contra partida os animais que receberam tratamento com Lumiracoxib, apresentaram um número significantemente maior de fungos viáveis em relação a todos os grupos. No epiplon (Figura 3B) os animais que receberam tratamento com IFN- $\gamma$ ou com Tetraciclina, apresentaram uma redução de fungos viáveis em relação aos animais apenas infectados, porém, essa redução não é significativamente estatística, porém o tratamento com Lumiracoxib acarretou um aumento significativamente maior de fungos viáveis em relação aos demais grupos. Quando fizemos esta analise no fígado (Figura 4A) os resultados encontrados no epiplon foram repetidos, os tratamentos com a citocina ou com 0 antibiótico tiveram uma redução da carga fúngica viável em relação aos animais tratados com Lumiracoxib, porém essa redução não foi significante quando comparados aos animais apenas infectados. No baço (Figura 4B) os animais infectados foram os animais que apresentaram a maior quantidade fungos viáveis, e os animais que receberam tratamento com IFN- $\gamma$ foi o grupo de animais que tiveram a menor quantidade de fungos viáveis. Porém em nenhum dos grupos houve uma diferença significativa.

Analisando em seu conjunto os resultados encontrados nos quatro órgãos analisados, a tendência observada foi de aumento do número de fungos viáveis pelo tratamento com um dos antiinflamatórios, e de queda dessa viabilidade com o emprego de Tetraciclina ou IFN- $\gamma$.

A atividade antibacteriana da Tetraciclina é amplamente referida na literatura, mas não há ainda relatos de sua atividade antifúngica, como aqui observados in vivo.

$\mathrm{O}$ tratamento com IFN- $\gamma$ confirma estudos que relataram atividade fungicida do IFN- $\gamma$ em relação ao $P$. brasiliensis (MOREIRA et al., 2008), e outros que demonstraram que o neutrófilo polimorfonuclear necessita de ativação via citocinas pró- 
inflamatórias como o INF- $\gamma$ para exercer seu efeito fagocítico e produzir metabólitos reativos do oxigênio (RODRIGUES et al., 2007). Em contrapartida, o tratamento com as drogas seletivas para a enzima COX, Celecoxib e Lumiracoxib resultou em um aumento significativo do número de P.brasiliensis viáveis em relação ao grupo apenas infectado, sugerindo que a administração de um desses antiinflamatórios torna os animais mais susceptíveis à instalação deste fungo. Estes resultados confirmam dados encontrados por nosso grupo que, utilizando um modelo de infecção de bsc por P.brasiliensis e tratamento com uma dessas drogas antiinflamatórias, observou um aumento do número de fungos viáveis, exacerbando a susceptibilidade à infecção (MOLINA et al., 2007).

\subsection{Quantificação de NO}

Através da quantificação da produção de óxido nítrico (NO), nos animais infectados por 15 dias pudemos constatar que no pulmão (Figura 5A), no epiplon (Figura 5B) e no fígado (Figura 6A) os animais tratados com IFN- $\gamma$ e os tratados com Tetraciclina apresentaram maior produção deste reativo do nitrogênio, sendo significativamente maiores que os demais grupos analisados. Os animais apenas infectados ou aqueles tratados com Celecoxib ou Lumiracoxib tiveram um resultado semelhante em relação à concentração deste reativo nesses três órgãos. No baço (Figura 6B) os animais apenas infectados tiveram uma produção significantemente maior de NO que os animais que receberam algum dos antiinflamatórios e não diferiram em relação ao tratamento com IFN- $\gamma$ ou Tetraciclina.

Aos 120 dias de infecção, verificamos que tanto no pulmão (Figura 7A), no epiplon (Figura 7B), no fígado (Figura 8A) e no baço (Figura 8B) o grupo de animais que receberam tratamento com IFN- $\gamma$ tiveram um número significativamente maior da concentração NO em relação aos demais grupos analisados, os animais apenas infectados, apresentaram valores semelhantes aos encontrados nos animais tratados com Lumiracoxib.

O aumento dos níveis de NO nos animais tratados com IFN- $\gamma$ já havia sido descrito em PCM experimental, indicando que esta citocina ativava principalmente macrófagos e conseqüentemente aumentava a produção de NO por essas células (MOREIRA et al., 2008). O aumento de NO através do tratamento com o antibiótico 
Tetraciclina também já foi relatado em um estudo, na qual a droga era adicionada à água de camundongos, o que trazia um aumento significativo da produção de NO em relação ao grupo de animais que bebia água normal (HJOBERG et al., 2004).

\subsection{Quantificação de citocinas em epíplon}

Foram quantificadas algumas citocinas presentes no epiplon, para elucidar o mecanismo de resposta dos animais em associação aos tratamentos, ou apenas à infecção desenvolvida. Através da dosagem da citocina formadora de monócitos e granulócitos GM-CSF (Figura 9A) pudemos verificar que aos 15 dias de infecção o grupo de animais que recebeu tratamento com o antibiótico Tetraciclina teve uma produção significantemente maior desta citocina em relação aos demais grupos, confirmando relato que a administração deste antibiótico causa um aumento de citocinas inflamatórias, principalmente a GM-CSF (HADDAD et al., 2004). Os animais apenas infectados com o fungo tiveram uma concentração significantemente maior de GM-CSF que os que receberam tratamento com IFN- $\mathrm{y}$, com Celecoxib ou com Lumiracoxib. Mais ainda, o tratamento com o antiinflamatório Celecoxib ou com o Lumiracoxib causou uma diminuição significativa da produção desta citocina em relação aos demais grupos. Aos 120 dias de infecção (Figura 11A) os animais que receberam tratamento com IFN- $\gamma$ tiveram uma produção significativamente maior que os demais grupos estudados, em contra partida o tratamento com GM-CSF no período tardio, foi o que obteve menor concentração desta proteína.

Analisando os níveis de produção da citocina IL-12, citocina que induz macrófagos a produzirem NO e IFN-y, observamos que a administração de Tetraciclina causou uma produção dessa citocina significantemente maior que observado nos demais grupos de animais. O tratamento com a citocina IFN-y (Figura 9B) resultou em uma produção significantemente maior de IL-12 que o observado no grupo apenas infectado com P.brasiliensis ou nos grupos tratados com Celecoxib ou com Lumiracoxib. O motivo para esse aumento pode ser uma ativação dos macrófagos pelo IFN- $\gamma$, com conseqüente secreção de IL-12 por essas células uma vez que esse fenômeno é classicamente observado. As concentrações de IL-12 encontradas nos animais tratados com Lumiracoxib ou Celecoxib e em animais apenas infectados se 
mostraram equivalentes. Aos 120 dias de infecção (Figura 11B) os valores encontrados no período inicial de infecção se mantiveram.

Quantificando a produção de TNF-a pudemos verificar que aos 15 dias de infecção (Figura 9C) a administração de Celecoxib ou Lumiracoxib proporcionou um aumento significativo dos níveis desta citocina em relação aos demais grupos, que se mantiveram com níveis equivalentes de TNF- $\alpha$, confirmando estudos que mostram que mesmo sendo medicamentos antiinflamatórios, com relação a esta citocina, no inicio de sua administração, determinaram um aumento da concentração de TNF- $\alpha$ (Ml et al., 2008). Como era esperado também os animais que receberam tratamento com IFN- $\gamma$ ou com Tetraciclina tiveram significantemente aumentados os níveis de TNF- $\alpha$ em relação ao grupo controle. No período tardio de infecção (Figura 11C), os animais que receberam a citocina recombinante IFN- $\gamma$ obtiveram uma concentração maior desta citocina analisada, que os demais grupos estudados.

Verificando, a quantidade da citocina IFN-y presente no sobrenadante do epiplon, para verificarmos se o tratamento induz a maior ou menor produção desta citocina, que possui além de sua capacidade fungicida, e ativadora de células inflamatórias, possui ação na síntese de colágeno e nos fibroblastos (JIMENEZ; FREUNDLICH; ROSENBLOOM, 1984) pudemos verificar que aos 15 dias de infecção (Figura 10A) os animais tratados com IFN-y e Tetraciclina tiveram um aumento significativo dos níveis desta citocina em relação aos demais grupos analisados. Quando analisamos essa citocina aos 120 dias de infecção (Figura 12A), continuamos a ver um aumento significativo dos animais que receberam tratamento com IFN-y continuaram com um aumento significativo dos valores desta citocina em relação aos demais tratamentos. De forma surpreendente os animais tratados com a droga antiinflamatória Lumiracoxib, tiveram um aumento dos níveis desta citocina em relação aos animais apenas infectados ou tratados com Tetraciclina.Os animais tratados com Tetraciclina, apenas infectados ou controle apresentaram níveis semelhantes.

Esses resultados mostram que a citocina IFN- $\gamma$ por si só, e por aumentar a concentração de IL-12 e provavelmente ativar macrófagos, faz com que aumente ainda mais a concentração de IFN- $\gamma$, já a Tetraciclina, no período tardio, acaba estimulando a liberação de TGF- $\beta$ e faz com que diminua a produção de IFN. Os 
animais que receberam antiinflamatório, por inibir os mecanismos de inflamação, inibem a produção desta citocina.

Para analisarmos a citocina TGF- $\beta$ que é considerada a citocina com maior influencia na formação de fibrose, além de aumentar vários componentes da matriz extracelular, e inibidor de sua degradação, foi analisado e aos 15 dias de infecção (Figura 10B) os animais infectados com algum dos antiinflamatórios apresentaram um aumento significativo dos níveis desta citocina em relação aos animais apenas controle, ou que os outros tratamentos. O tratamento com IFN-y ou com Tetraciclina teve uma redução significativamente menor da produção desta citocina, em relação aos animais apenas infectados. Aos 120 dias de infecção (Figura 12B), os animais tratados com o antibiótico Tetraciclina, apresentaram um aumento significativo dos níveis desta citocina em relação aos demais grupos estudados. O tratamento com a citocina IFN-y ocasionou uma redução significativa dos níveis desta citocina em relação aos animais apenas infectados.

Estes resultados mostram que os animais que tiveram um aumento desta citocina, apresentaram um aumento do depósito de colágeno nas lesões, este fato provavelmente pode estar associado ao fato, de que a produção de TGF- $\beta$ impede a degradação de componentes da MEC.

\subsection{Quantificação de metaloproteinases no epíplon}

Através do teste de ELISA, quantificamos a quantidade de concentração de MMP-2 e MMP-9 no epíplon dos animais.

A MMP-9 aos 15 dias de infecção pudemos verificar que os animais tratados com IFN- $\gamma$ e Tetraciclina foram os animais que tiveram menor concentração de MMP-9 dos grupos analisados (Figura 13A). Essa diferença foi estatisticamente significativa.

Aos 120 dias de infecção pudemos verificar que o tratamento com IFN-y continuou tendo uma concentração significativamente menor deste produto em relação aos animais apenas infectados (Figura 13B).

Já os níveis de MMP-2 se mantiveram baixos aos 15 (Figura 14A) e 120 dias (Figura 14B) e em todos os esquemas terapêuticos. 
Estes resultados comprovam estudos que relatam o poder inibitório desta citocina em relação as MMPs 2 e 9 (FONTANA et al., 2010). A formação de uma grande quantidade de colágenos pelos tratamentos com antiinflamatórios não parece ser influenciada pelas MMPs, confirmando estudos que mostram que inibidores de COX fazem uma regulação negativa deste componente (KURIHARA et al., 2009). O tratamento com Tetraciclina no período inicial de infecção mostrou uma inibição das MMPs, confirmando trabalhos que relatam essa seu importante papel (PASTERNAK; ASPENBERG, 2009).

\subsection{Análise histopatológica}

A análise histopatológica permitiu observar algumas diferenças importantes no padrão geral das lesões, na composição e morfologia celular e na quantidade de fungos presentes nos órgãos dos animais que receberam os diferentes tratamentos em relação aos animais apenas infectados, no período de 15 e 120 dias. Aos 15 dias, através da impregnação com prata, pudemos observar que os animais apenas infectados apresentaram o baço, o fígado e o pulmão intactos, sem presença detectável de focos fúngicos (Prancha 1). Os animais tratados com IFN-Y (Prancha 2) ou com Tetraciclina (Prancha 3) também não apresentaram fungos no baço, fígado ou pulmão. No entanto, os animais tratados com antiinflamatórios: Lumiracoxib (Prancha 4) ou Celecoxib (Prancha 5), apresentaram focos fúngicos na cápsula desses três órgãos, tendo os fungos encontrados, morfologia típica. Aos 120 dias de infecção, tanto os animais apenas infectados (Prancha 6) os animais tratados com IFN (Prancha 7) com Tetraciclina (Prancha 8) ou com Lumiracoxib (Prancha 9) não apresentaram foco fúngico em nenhum dos órgãos. Quando fizemos a análise do epiplon através desta coloração, observamos que aos 15 dias os animais que foram infectados com salina (Prancha 10) não apresentaram fungos nesse órgão, os animais apenas infectados apresentavam fungos dispostos em grupos e disseminados pelo órgão, na maioria com morfologia típica (Prancha 11). Os animais tratados com IFN-y (Prancha 12) ou com Tetraciclina (Prancha 13), apresentaram fungos com morfologia variando numa gradação de típicos para atípicos e sempre em determinadas regiões do parênquima dos órgãos, apresentando-se agrupados. O tratamento com Lumiracoxib (Prancha 14) ou com 
Celecoxib (Prancha 15) causou uma disseminação generalizada de fungos por todo o epiplon, chegando até a cápsula do pâncreas sendo que quase $100 \%$ desses fungos tinham morfologia típica preservada.

Os animais que foram infectados com salina, depois de 120 dias apresentavam o epiplon sem qualquer presença de fungos (Prancha 16). Quando observamos os animais infectados por 120 dias, vimos que os animais apenas infectados, continuavam a apresentar fungos disseminados, com sua morfologia típica (Prancha 17) Os animais tratados com IFN-y (Prancha 18) ou com Tetraciclina (Prancha 19) apresentaram a grande maioria da população fúngica deste órgão com a morfologia atípica. Os animais tratados com Lumiracoxib tiverem a grande maioria dos fungos com sua morfologia preservada (Prancha 20).

A avaliação do aspecto geral do granuloma e identificação das populações celulares presentes nas lesões foi realizada empregando-se a coloração $\mathrm{HE}$, e revelou que nenhum dos grupos de animais apresentou no período de 15 dias de infecção, granulomas no pulmão (Prancha 21 e 22), no fígado (Prancha 23 e 24) ou no baço (Prancha 25 e 26). No epiplon dos animais apenas infectados com $P$. brasiliensis, observamos granulomas com aspecto frouxo, pouco organizado, possivelmente permitindo a disseminação de alguns fungos pelo tecido, com presença de células gigantes multinucleadas e macrófagos ao redor dos fungos (Prancha 11). Os animais tratados com IFN- $\gamma$, apresentaram granulomas compactos, circunscrevendo os fungos, provavelmente impedindo a sua disseminação, com presença de neutrófilos e linfócitos (Prancha 12). Nos animais que receberam tratamento com Tetraciclina, não houve formação de granulomas, observando-se um infiltrado de linfócitos no órgão (Prancha 13). Os animais tratados com Lumiracoxib (Prancha 14) ou com Celecoxib (Prancha 15) apresentaram lesões tão desorganizadas, que não era possível discriminar os limites do granuloma, indicando disseminação generalizada por todo o tecido e invasão dos órgãos vizinhos. O tratamento com antiinflamatórios revelou um infiltrado de células gigantes multinucleadas que chegavam a ter até 16 núcleos.

Aos 120 dias de infecção, os animais que receberam infecção com salina, continuaram a não apresentar lesão e sem a presença de qualquer tipo de célula presente no sangue (Prancha 16), os animais apenas infectados (Prancha 17), mantiveram a presença de um granuloma frouxo, com disseminação fúngica, com 
um infiltrado de polimorfonucleares sobre as células fúngicas. Os animais tratados com IFN-y (Prancha 18) apresentaram um granuloma compacto, mantendo os fungos dentro dos limites desse granuloma, apresentou grande quantidade de neutrófilos e de células gigantes. Os animais que receberam tratamento com Tetraciclina (Prancha 19), neste período apresentou um granuloma bem delimitado, e muito compacto, e os fungos não conseguiram se disseminar. As células inflamatórias também cercaram todas as células fúngicas. Os animais que receberam tratamento com Lumiracoxib (Prancha 20), neste período de infecção apresentaram disseminação fúngica, porém menos acentuada que na infecção aguda, um granuloma frouxo com poucas fibras colágenas, e um infiltrado de células gigantes multinucleadas.

Fazendo a analise do epíplon através da coloração de Picrosirius pudemos verificar que aos 15 dias de infecção, os animais apenas infectados com o fungo apresentaram depósitos de fibras colágenas no epiplon, com um aspecto que variava de organizado para desorganizado; as fibras colágenas eram de morfologia fina e não formavam uma barreira eficiente para a contenção do fungo. Quando a luz que incidia nessas lâminas foi polarizada essas fibras mostraram serem possivelmente fibras colágenas do tipo III ou IV (Prancha 27). Os animais tratados com IFN-y apresentavam depósitos de fibras colágenas com aspecto organizado que variavam sua espessura de fina a grossa, aparentemente formando uma barreira para conter os fungos. Quando esses cortes foram analisados à luz polarizada, as fibras colágenas apresentaram morfologia indicativa de colágeno do tipo I e colágeno do tipo III ou IV (Prancha 28). Os animais que receberam Tetraciclina apresentaram um depósito de colágeno quase imperceptível, associado à não formação de granuloma. Quando analisamos à luz polarizada pudemos discernir apenas um tecido escuro, sem evidencia alguma de fibras (Prancha 29). Os camundongos que receberam tratamento com Lumiracoxib (Prancha 30) ou Celecoxib (Prancha 31) apresentaram uma deposição enorme de colágeno por todo o órgão. O aspecto dessas fibras era muito grosseiro e estavam depositadas de forma completamente desorganizada e não se constituíam aparentemente em barreira para a contenção fúngica. Ao polarizar a luz pudemos verificar que as fibras colágenas depositadas sugeriam serem fibras colágenas do tipo I. 
Aos verificarmos o epíplon dos animais com 120 dias de infecção, pudemos observar que os animais apenas infectados (Prancha 32) apresentaram depósito de fibras colágenas com morfologia fina, organizada, porém não conseguia fechar o granuloma, impossibilitando a contenção fúngica, ao polarizarmos o corte, podemos ver fibras que varias de grossa para finas, podendo ser de colágeno do tipo I e IV. Os animais tratados com IFN- $\gamma$ apresentaram granulomas bem definidos, com grande quantidade de fibras colágenas grossas. Ao polarizarmos a luz, podemos ver essas fibras bem organizadas, formando um granuloma compacto (Prancha 33). Os camundongos infectados e tratados com o antibiótico Tetracilcina apresentaram uma enorme quantidade de fibras colágenas grossas e finas, distribuídas por todo o tecido, formando um granuloma compacto impedindo a disseminação fúngica. Ao polarizarmos o corte, podemos ver as fibras bem organizadas, todas mantendo 0 mesmo sentido (Prancha 34). Os animais tratados com Lumiracoxib apresentam poucas fibras colágenas, mais e não foi capaz de conter a disseminação fúngica, quando polarizamos a luz, vemos poucas fibras, desorganizada (Prancha 35).

\subsection{Quantificação de hidroxiprolina}

A quantificação do aminoácido secundário hidroxiprolina, que é um dos produtos da síntese e degradação do colágeno foi feita através de um método de HPLC que utiliza cromatografia de alta performance, padronizada por Lange e Mályusz (1994) e simplificada e aplicada por nosso grupo. Nesta etapa do trabalho analisamos a quantidade de hidroxiprolina presente apenas no epiplon dos animais, devido a esse órgão ter sido o mais afetado e o que demonstrou maiores diferenças entre os grupos analisados. Na etapa de padronização, verificamos qual era o tempo de retenção da hidroxiprolina e se a reação era dose-dependente, utilizando padrões com concentrações de 10mM (Figura 15A) e 1mM (Figura 15B) deste aminoácido para confirmar que o pico em que mediamos as áreas que a hidroxiprolina era de fato esse aminoácido. Feito isso, analisamos as amostras e verificamos que aos 15 dias de infecção os animais apenas infectados com o fungo foram os que apresentaram a menor concentração de hidroxiprolina. Tanto os animais tratados com IFN-y como os com Tetraciclina apresentaram uma concentração maior de hidroxiprolina que os animais apenas infectados, porém essa diferença não foi 
significante. No entanto, os animais que receberam tratamento com Lumiracoxib ou com Celecoxib apresentaram concentrações de hidroxiprolina semelhantes entre si, porém, significantemente maiores que os outros grupos tratados ou que o grupo apenas infectado (Figura 16). Aos 120 dias de infecção, os animais apenas infectados e os animais tratados com IFN- $\gamma$ apresentaram os mesmos valores de concentração de hidroxiprolina, sendo um pouco menor está concentração, que a encontrada nos animais tratados com Lumiracoxib. Os animais tratados com Tetraciclina apresentaram uma concentração significativamente maior de hidroxiprolina, que os demais grupos analisados (Figura 17).

Os animais que receberam tratamento com IFN- $\gamma$ ou os animais apenas infectados, mantiveram uma quantidade semelhante de colágeno nas lesões, diferindo apenas na arquitetura do granuloma, resultando em uma concentração semelhante de hidroxiprolina. Os animais que receberam tratamento com Tetraciclina no período inicial de infecção tiveram um menor depósito de colágeno e isso refletiu na concentração de hidroxiprolina que foi a menor encontrada de todos os grupos, porém no período tardio, esses animais tiveram um grande depósito de colágeno na lesão, e isso refletiu no aumento da concentração de hidroxiprolina. Finalmente os animais que receberam tratamento com algum dos antiinflamatórios, no período inicial, pela análise de colágeno total, mostraram uma grande quantidade destas fibras no tecido e tiveram um aumento significativo da concentração de hidroxiprolina, e na infecção tardia tiveram um menor depósito de colágeno, e menor concentração de hidroxiprolina, mostrando que a quantidade deste aminoácido está intimamente relacionada com o de depósito de colágeno nas lesões.

Podemos, portanto sugerir uma relação direta com o grau de depósito de colágenos observados nas lâminas histológicas do epiplon. Ainda não foi relatada na literatura a quantificação de hidroxiprolina como parâmetro para aferir o efeito de tratamento com algum desses fármacos que atuam na MEC.

\subsection{Detecção imunohistoquímica de colágeno I no epíplon}

No período de 15 dias de infecção, os animais apenas infectados (Prancha 36A) apresentaram marcação positiva para colágeno tipo I, sendo possível a visualização dessas fibras marcadas formando um granuloma, com solução de continuidade em 
sua cápsula, que permitiria a disseminação do fungo. Os animais tratados com IFN- $\gamma$ (Prancha 36B) também apresentaram marcação positiva para colágeno I, porém em menor grau que os animais apenas infectados. As fibras marcadas formavam um granuloma compacto, sugerindo limitação de disseminação fúngica por este tipo de colágeno. Os animais tratados com Tetraciclina (Prancha 36C) apresentaram marcação negativa para este tipo de colágeno, confirmando nossos dados obtidos através da análise histopatológica com coloração $\mathrm{HE}$, em que mostrávamos que esse grupo de animais não produz granulomas e apresentaram ausência de fibras colágenas do tipo I. Os animais tratados com Lumiracoxib (Prancha 36D) ou com Celecoxib (Prancha 36E) apresentaram uma intensa marcação positiva para colágeno I, cujas fibras se alongavam por todo o tecido, e se apresentavam orientadas em diversas direções. Essa desorganização das fibras colágenas do tipo I favoreceria a disseminação fúngica, pois não há delimitação do granuloma. Um corte foi testado sem a adição do anticorpo primário (Prancha 36F) para controle negativo da reação.

Aos 120 dias de infecção pudemos verificar os animais apenas infectados (Prancha 37A) tiveram marcação positiva para esta reação, podendo ser observado a formação de granulomas frouxos. Os animais infectados e tratados com a citocina IFN- $\gamma$ (Prancha 37B) obtiveram marcação positiva, e analisando a imagem, conseguimos ver a formação de um granuloma compacto, bem delimitado, aonde as fibras formam uma lesão que formam uma barreira contra a disseminação fúngica. Os animais tratados com Tetraciclina (Prancha $37 \mathrm{C}$ ) tiveram uma marcação muito forme, mostrando vários granulomas bem compactos, aonde conseguem impedir a disseminação fúngica. Os animais tratados com Lumiracoxib (Prancha 37D) tiveram uma marcação positiva, porém discreta, aonde pudemos verificar um pequeno depósito de colágeno no tecido.

De modo geral, as características da disposição e da quantidade das fibras colágenas do tipo I refletiram o aspecto verificado pela analise do colágeno total, sugerindo que esta classe de colágeno seja a principal responsável pelo tipo de arquitetura do granuloma paracocidioidomicótico e que seja um tipo de colágeno muito afetado pelos diferentes tratamentos aqui empregados. 


\subsection{Quantificação da área de lesão}

A área das lesões foi quantificada analisando o tamanho da lesão, sendo a porcentagem de quanto à lesão pega da imagem, e a quantificação fúngica foi feita pela contagem de cada célula fúngica presente na imagem adquirida (Figura 18). Quanto à área de lesão, aos 15 dias os animais infectados e tratados com um dos antiinflamatórios, apresentaram uma lesão significativamente maior (Figura 19A). Aos 120 dias, os animais apenas infectados e tratados com Tetraciclina, foi o grupo de animais que apresentou a maior lesão, estatisticamente significativa (Figura 19B). Quanto à disseminação fúngica, pudemos verificar que aos 15 dias (Figura 20A) e aos 120 dias (Figura 20B) de infecção, os animais tratados com um dos antiinflamatórios foram os que apresentaram a maior quantidade de células fúngicas disseminadas no tecido.

Nos achadas mostram que o tamanho da lesão não é o fator determinante para a contenção da disseminação fúngica, e sim a arquitetura que essa lesão apresenta, para impedir que o fungo se dissemine.

\subsection{Quantificação do colágeno total nas lesões}

A quantificação do colágeno total das lesões foi analisada pelo mesmo método utilizado, para quantificação da área das lesões. Nela pudemos verificar que aos 15 dias de infecção, os animais que apresentaram a maior quantidade de colágenos foram os tratados com um dos antiinflamatórios (Figura 21A) que nos demais grupos analisados. Já aos 120 dias de infecção (Figura 21B), os animais que apresentaram uma quantidade de colágeno total nas lesões, significativamente maior que os demais grupos, foram os animais tratados com Tetraciclina.

Estes resultados confirmam todos os achados, mostrando que a quantidade de hidroxiprolina presente na lesão, e seu tamanho, é proporcional com a quantidade de colágeno na lesão. 


\subsection{Análise de sobrevida}

O teste de sobrevida foi feito com animais apenas infectados e animais tratado com o antibiótico Tetraciclina. Os animais apenas infectados começaram a morrer a partir do $60^{\circ}$ dia, aos $200^{\circ}$ dia não havia mais animal apenas infectado vivo. Já os animais que receberam tratamento com Tetraciclina, começaram a morrer a partir do dia $80^{\circ}$ e no $220^{\circ}$ ainda existiam mais de $60 \%$ dos animais vivos. Estes dados comprovam o aumento da sobrevida dos animais infectados com P.brasiliensis e que receberam tratamento com Tetraciclina (Figura 22). 

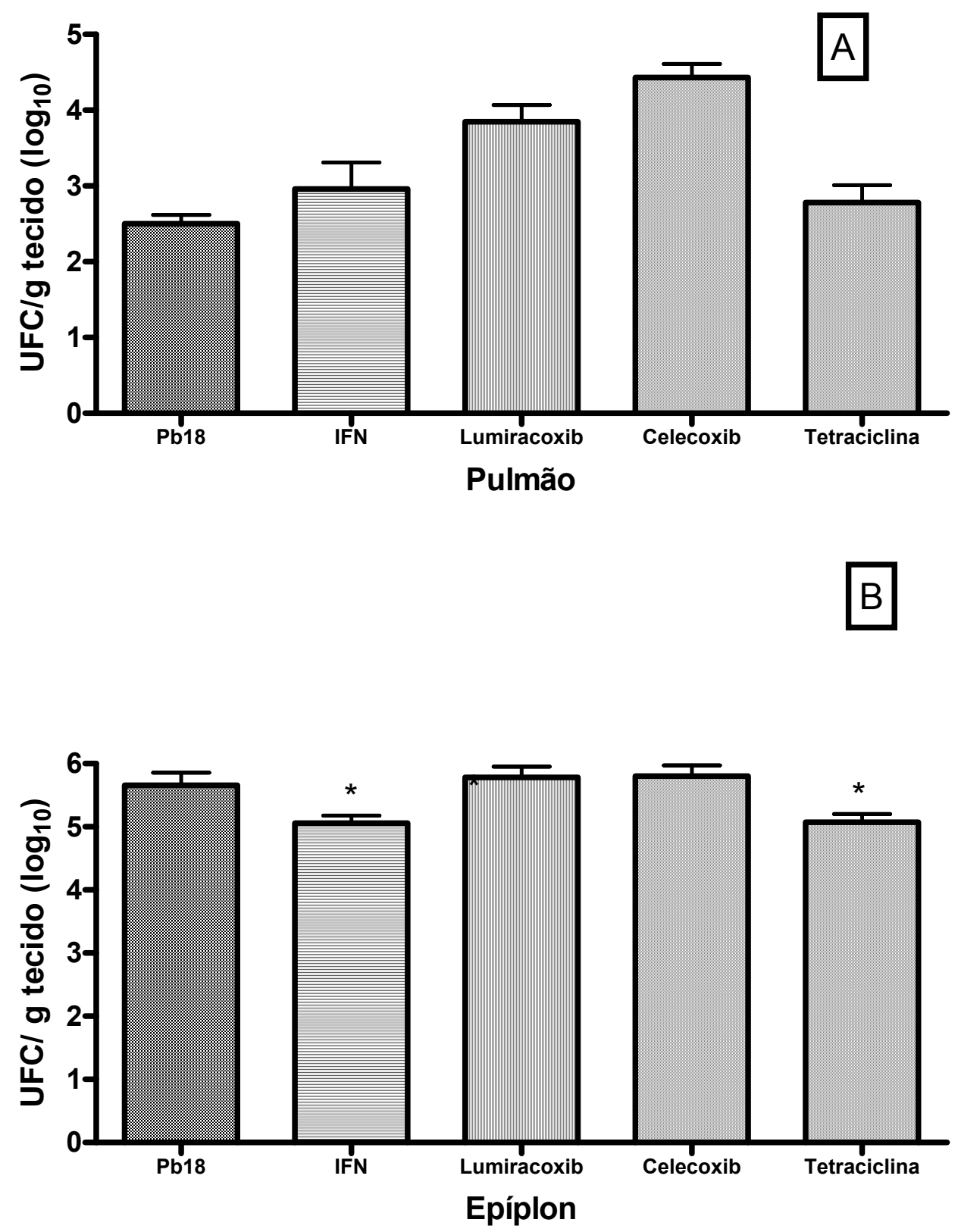

Figura 1 - Quantificação de fungos viáveis em camundongos B10.A inoculados com Pb18 e submetido a um dos tratamentos (IFN- $\gamma$; Tetraciclina; Lumiracoxib; Celecoxib) ou apenas infectados, aos 15 dias de infecção. As barras representam o erro médio padrão.

- - Diferença estatística significativa com $p<0,05$ em relação aos controles apenas infectados. 


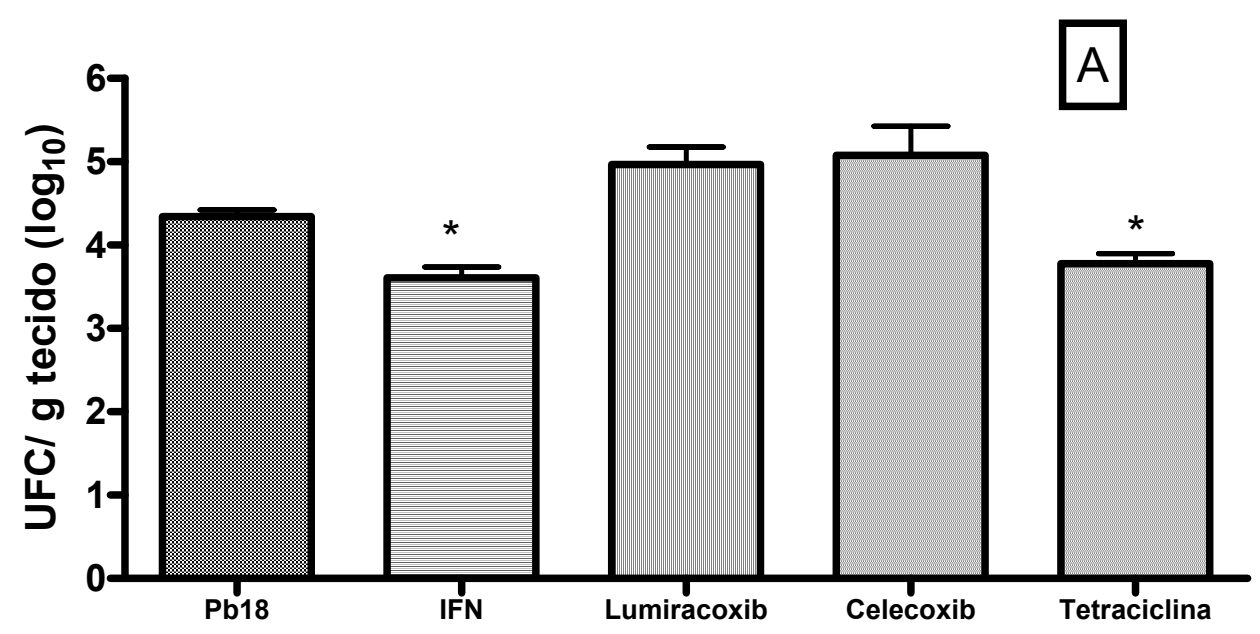

Fígado

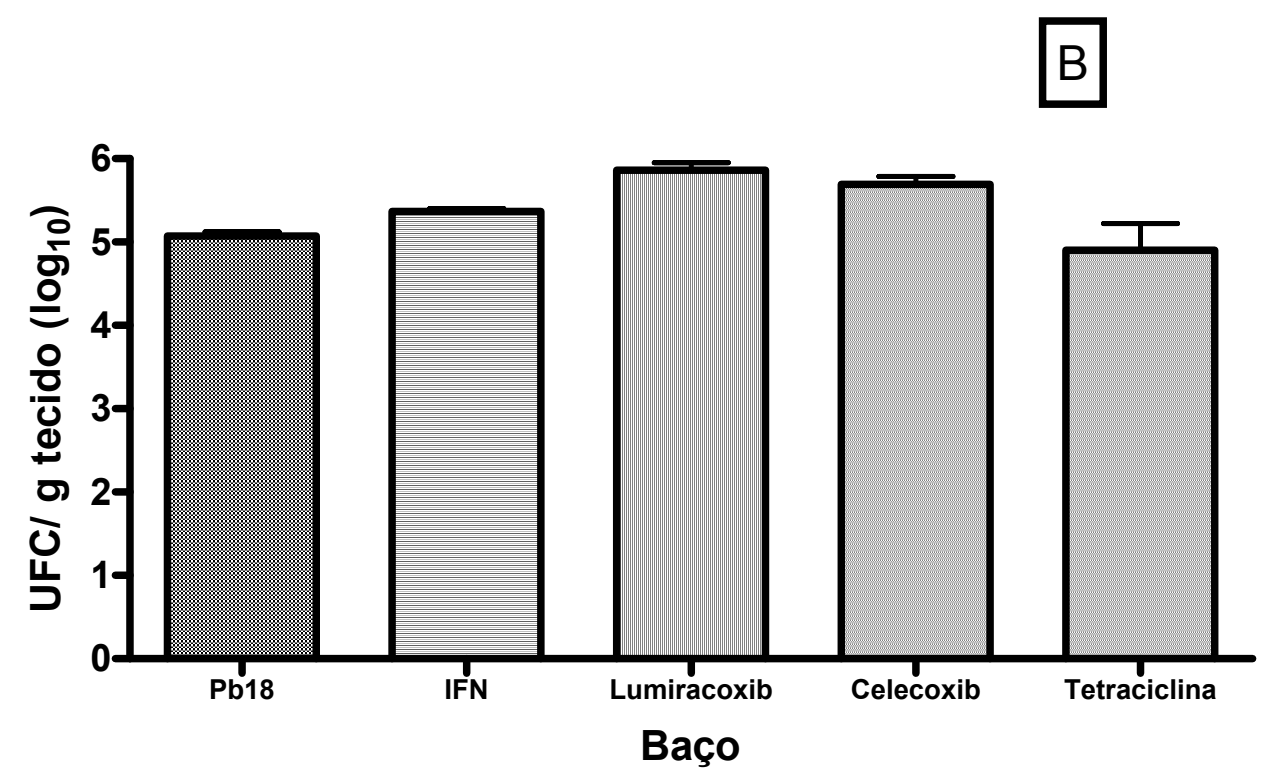

Figura 2 - Quantificação de fungos viáveis em camundongos B10.A inoculados com Pb18 e submetido a um dos tratamentos (IFN- $\gamma$; Tetraciclina; Lumiracoxib; Celecoxib) ou apenas infectados, aos 15 dias de infecção. As barras representam o erro médio padrão.

* - Diferença estatística significativa com $p<0,05$ em relação aos controles apenas infectados. 

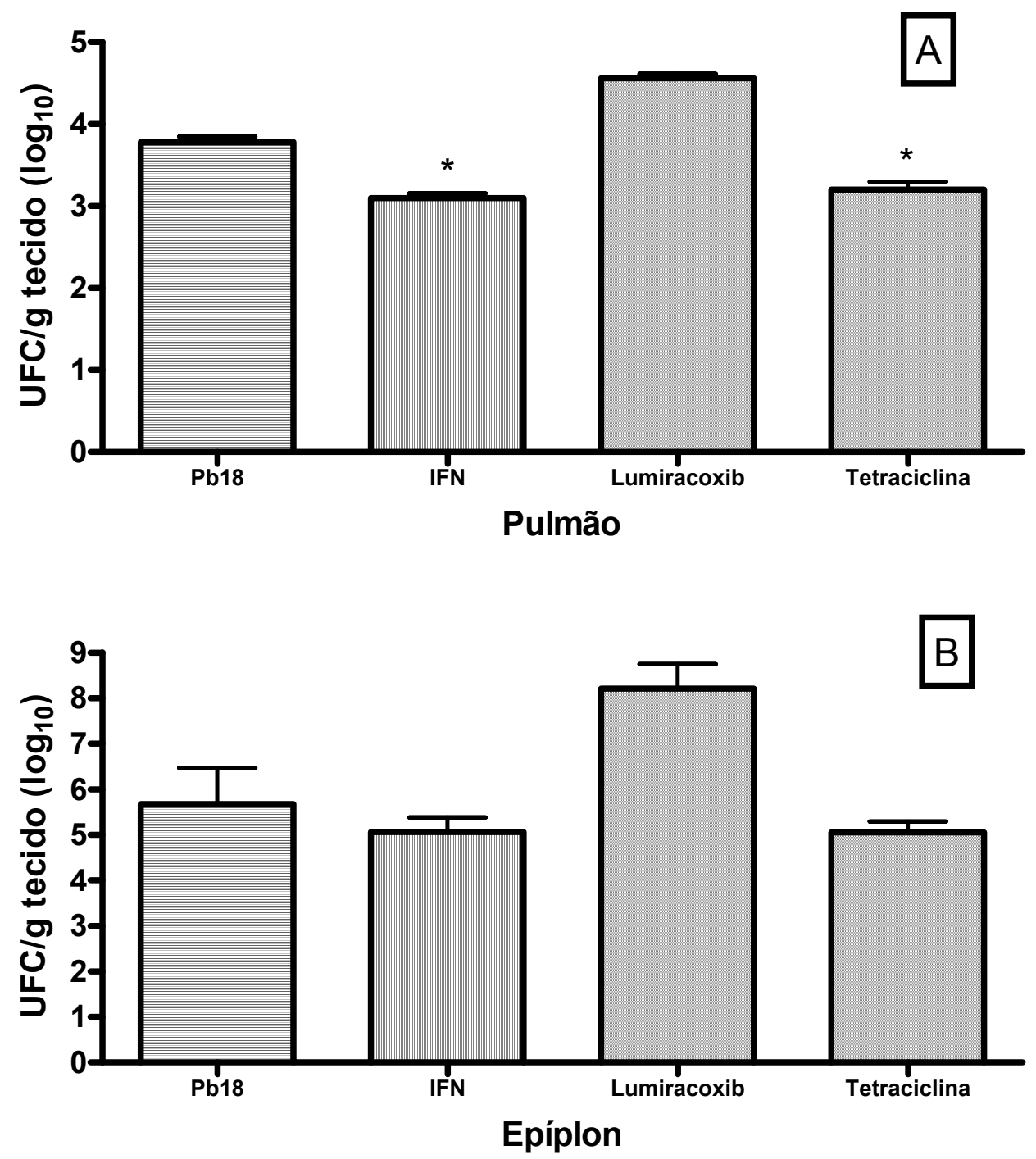

Figura 3 - Quantificação de fungos viáveis em camundongos B10.A inoculados com $\mathrm{Pb} 18$ e submetido a um dos tratamentos (IFN- $\gamma$; Tetraciclina; Lumiracoxib) ou apenas infectados, aos 120 dias de infecção. As barras representam o erro médio padrão.

* - Diferença estatística significativa com $p<0,05$ em relação aos controles apenas infectados. 


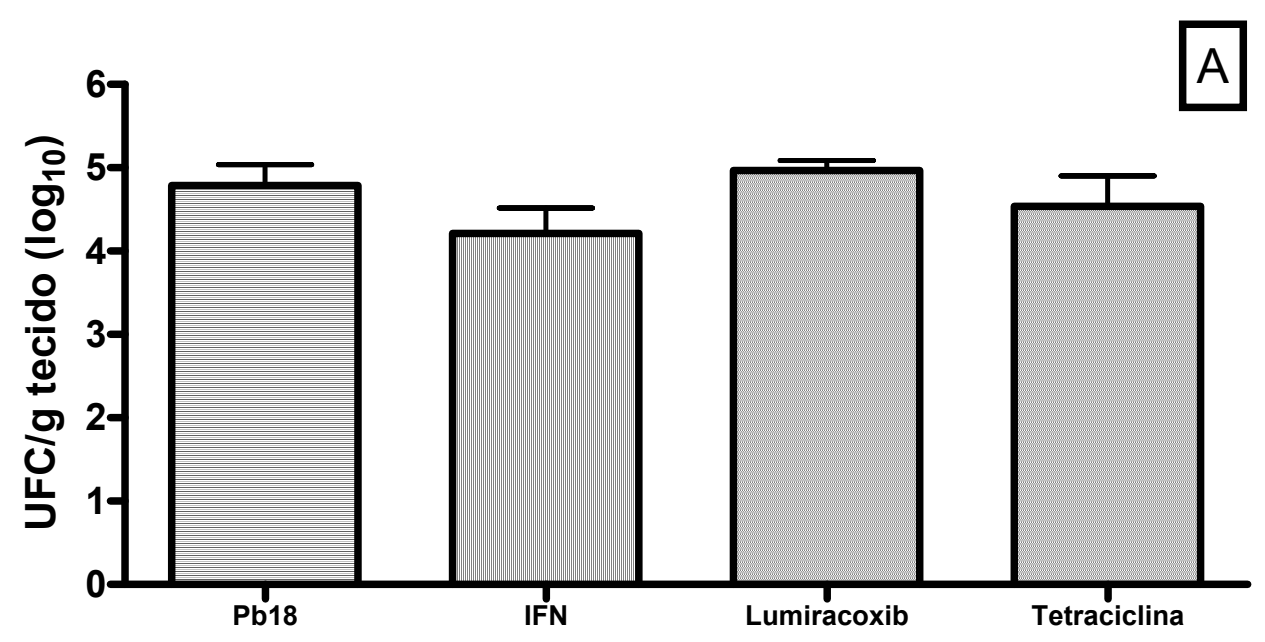

Fígado

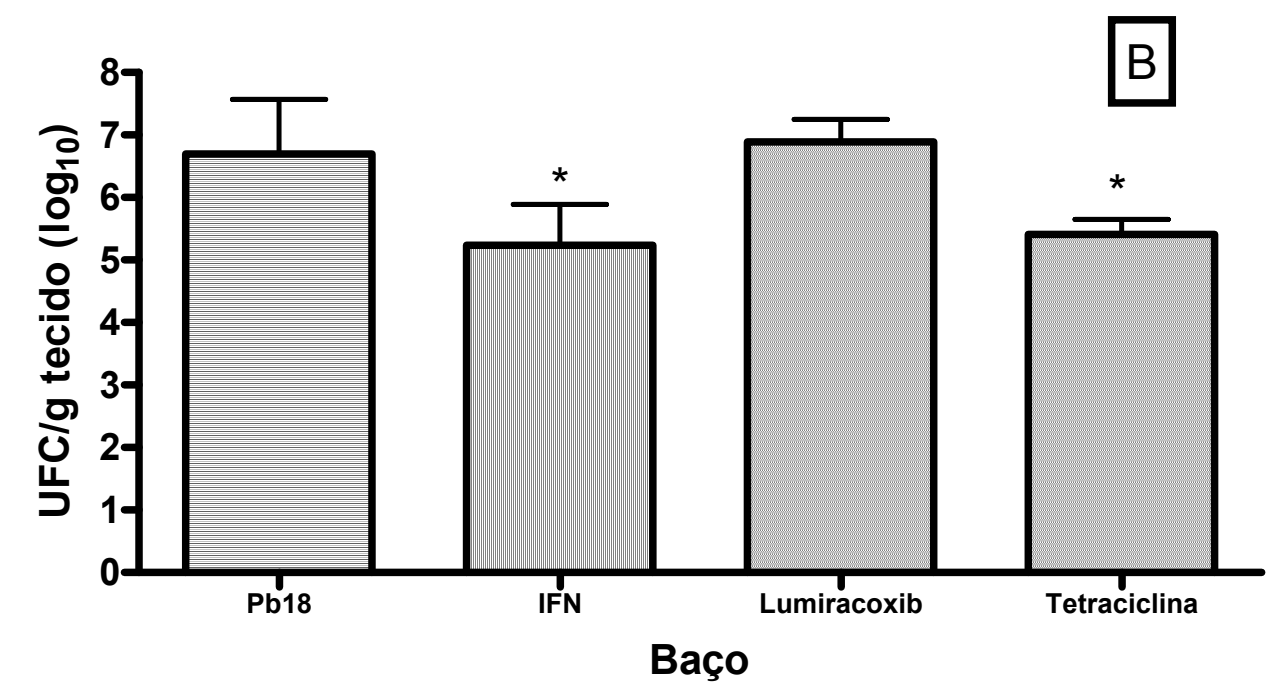

Figura 4 - Quantificação de fungos viáveis em camundongos B10.A inoculados com $\mathrm{Pb} 18$ e submetido a um dos tratamentos (IFN- - ; Tetraciclina; Lumiracoxib) ou apenas infectados, aos $\mathbf{1 2 0}$ dias de infecção. As barras representam o erro médio padrão.

* - Diferença estatística significativa com $p<0,05$ em relação aos controles apenas infectados. 

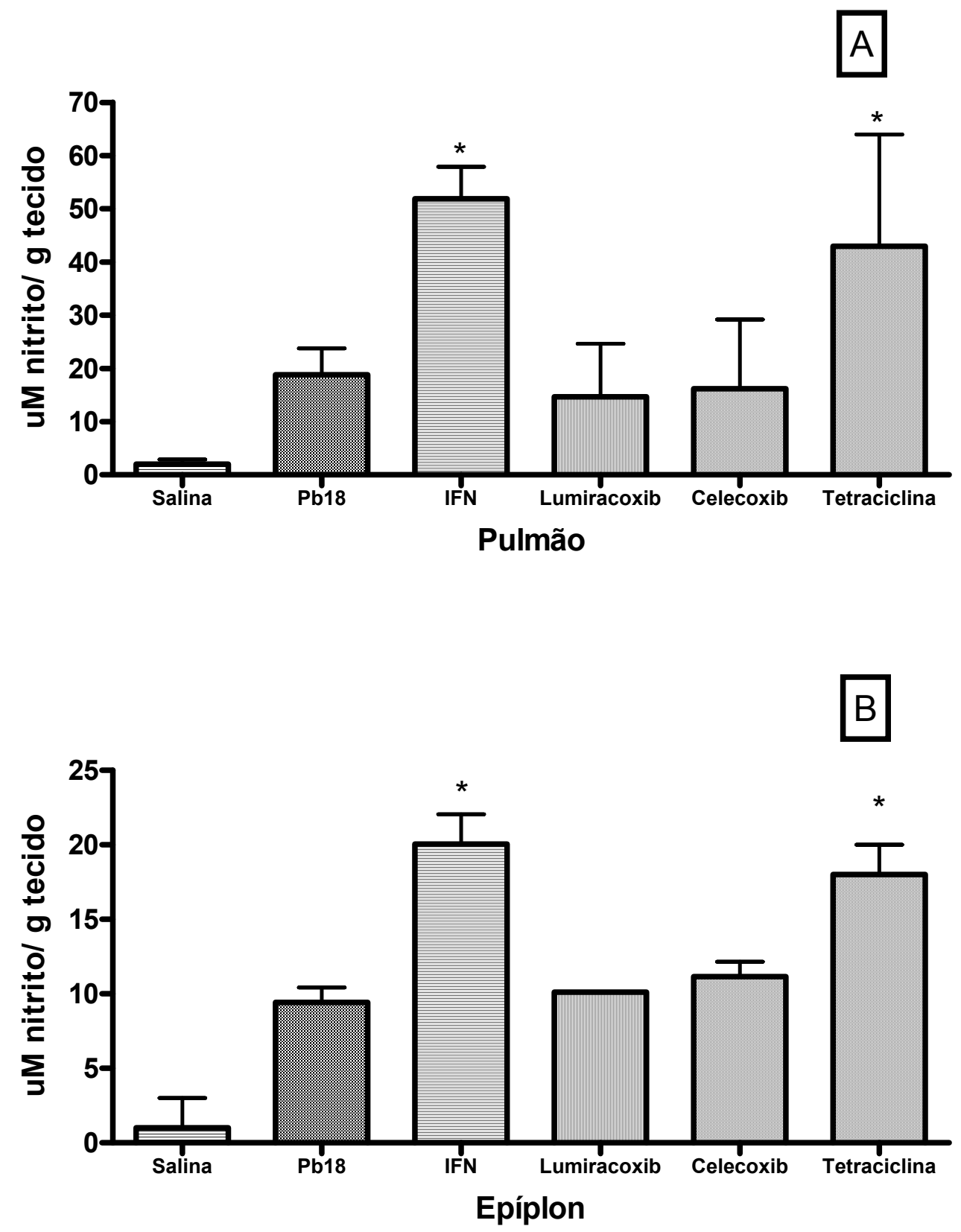

Figura 5 - Determinação da concentração de NO, mensurado sob a forma de nitrito, em camundongos B10.A inoculados com Pb18 e submetido a um dos tratamentos (IFN- $\gamma$; Tetraciclina; Lumiracoxib; Celecoxib) ou apenas infectados, aos 15 dias de infecção. As barras representam o erro médio padrão.

* - Diferença estatística significativa com $p<0,05$ em relação aos controles apenas infectados. 


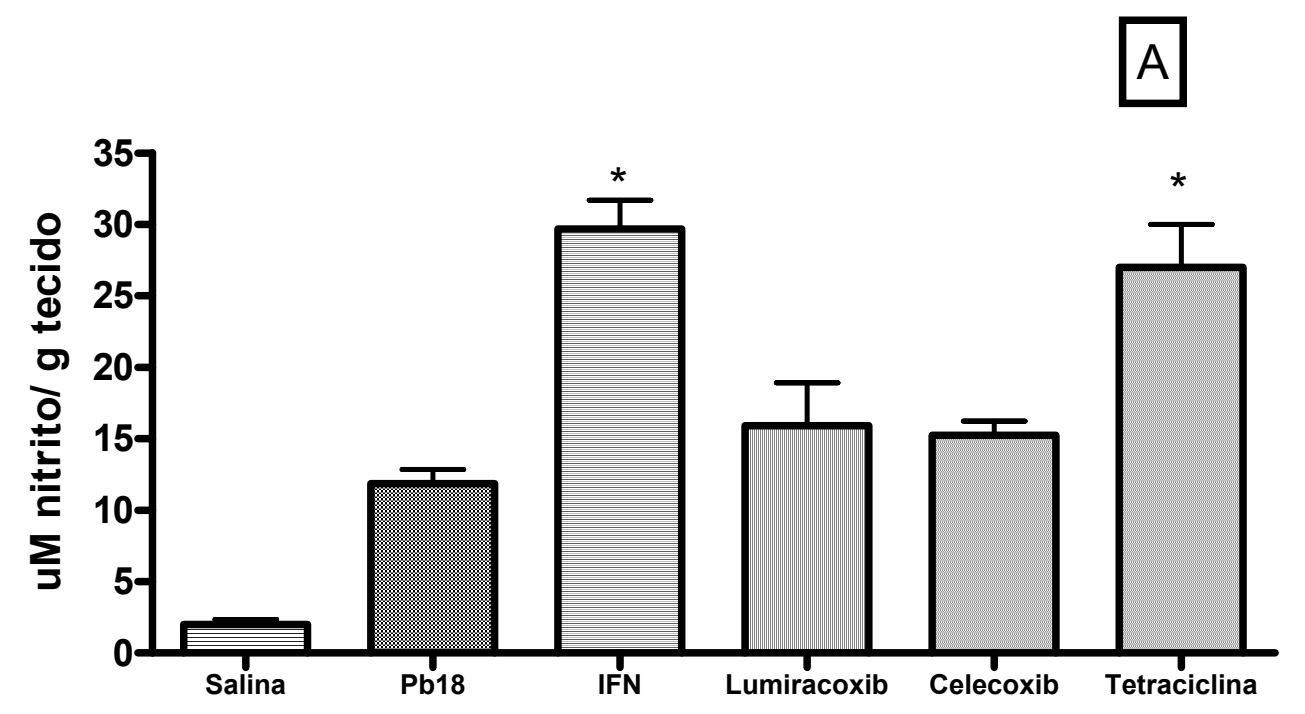

Fígado

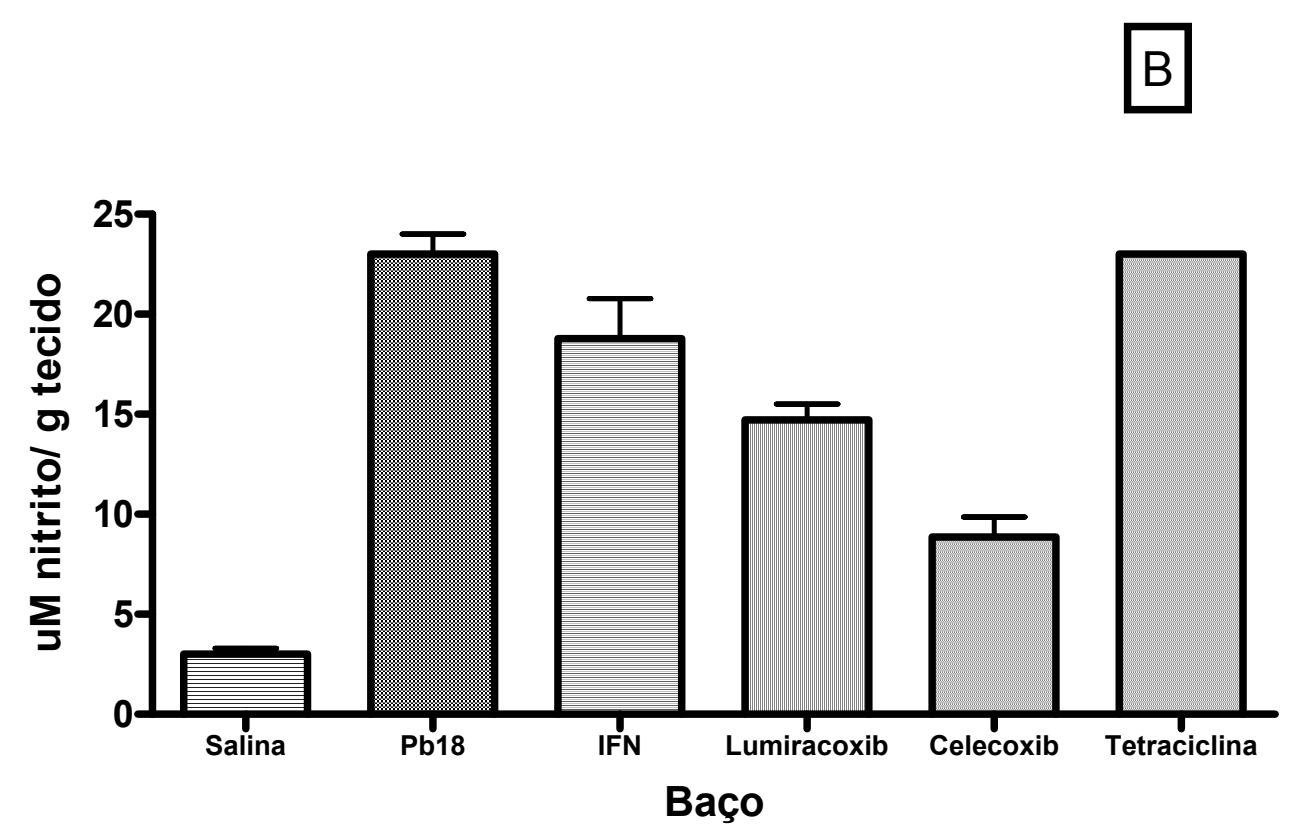

Figura 6 - Determinação da concentração de NO, mensurado sob a forma de nitrito, em camundongos B10.A inoculados com $\mathrm{Pb} 18$ e submetido a um dos tratamentos (IFN- $\gamma$; Tetraciclina; Lumiracoxib; Celecoxib) ou apenas infectados, aos 15 dias de infecção. As barras representam o erro médio padrão.

* - Diferença estatística significativa com p < 0,05 em relação aos controles apenas infectados. 

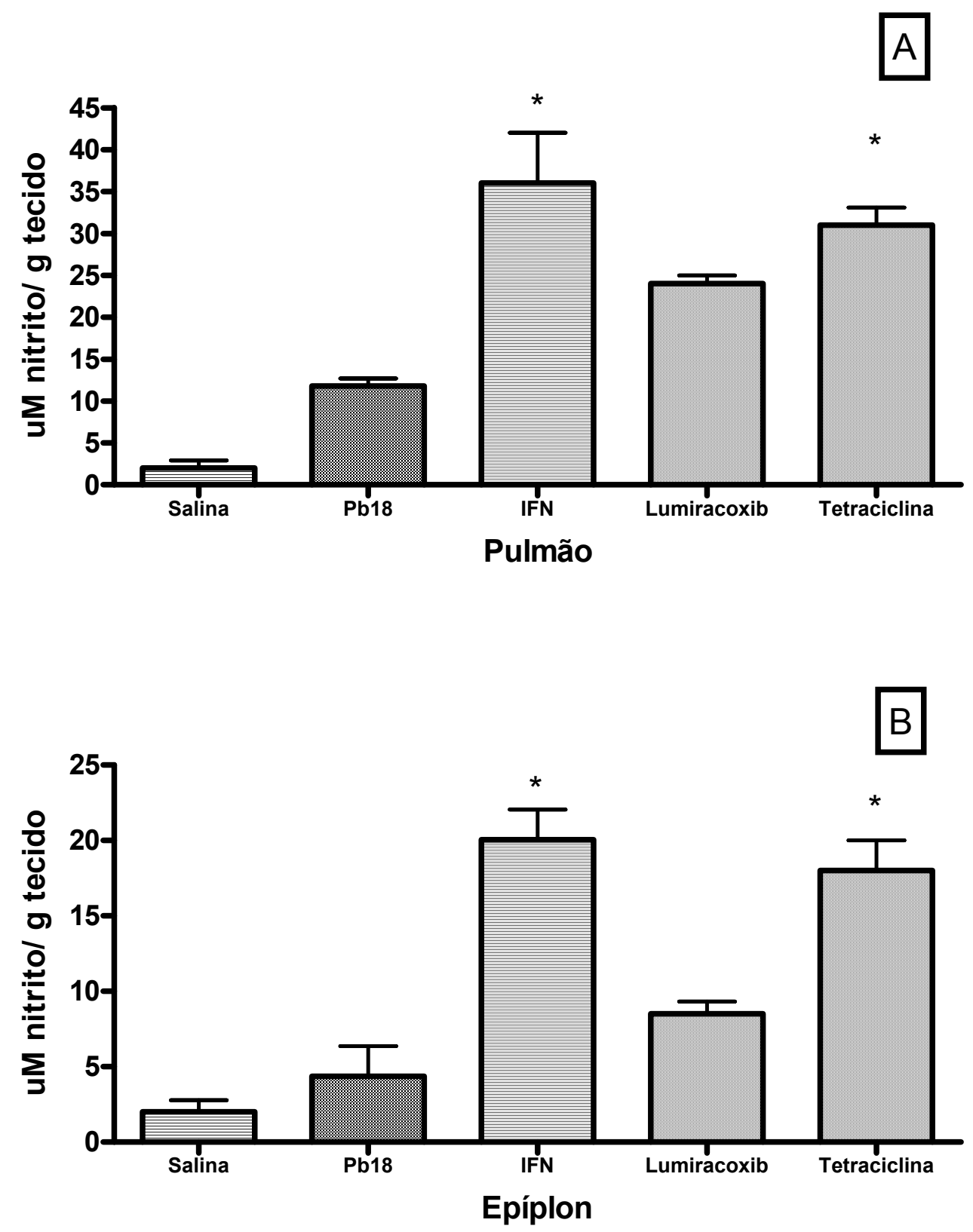

Figura 7 - Determinação da concentração de NO, mensurado sob a forma de nitrito, em camundongos B10.A inoculados com Pb18 e submetido a um dos tratamentos (IFN- $\gamma$; Tetraciclina; Lumiracoxib) ou apenas infectados, aos 120 dias de infecção. As barras representam o erro médio padrão.

* - Diferença estatística significativa com $p<0,05$ em relação aos controles apenas infectados. 


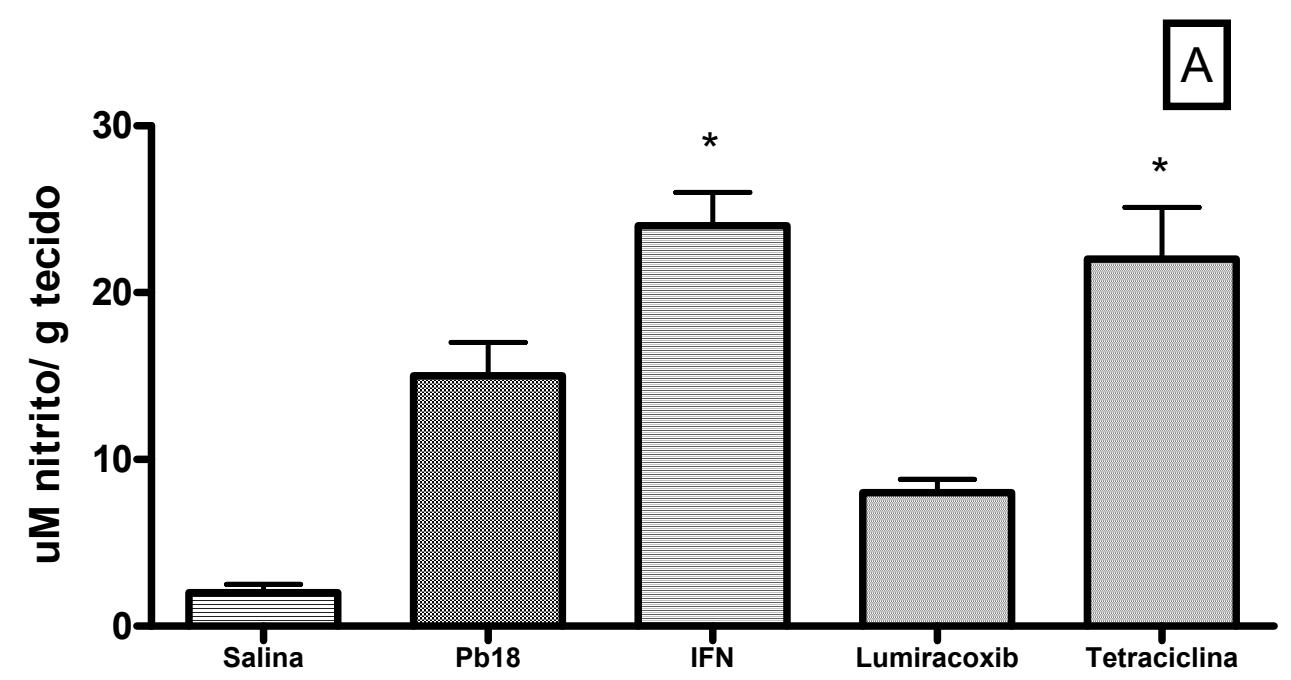

Fígado

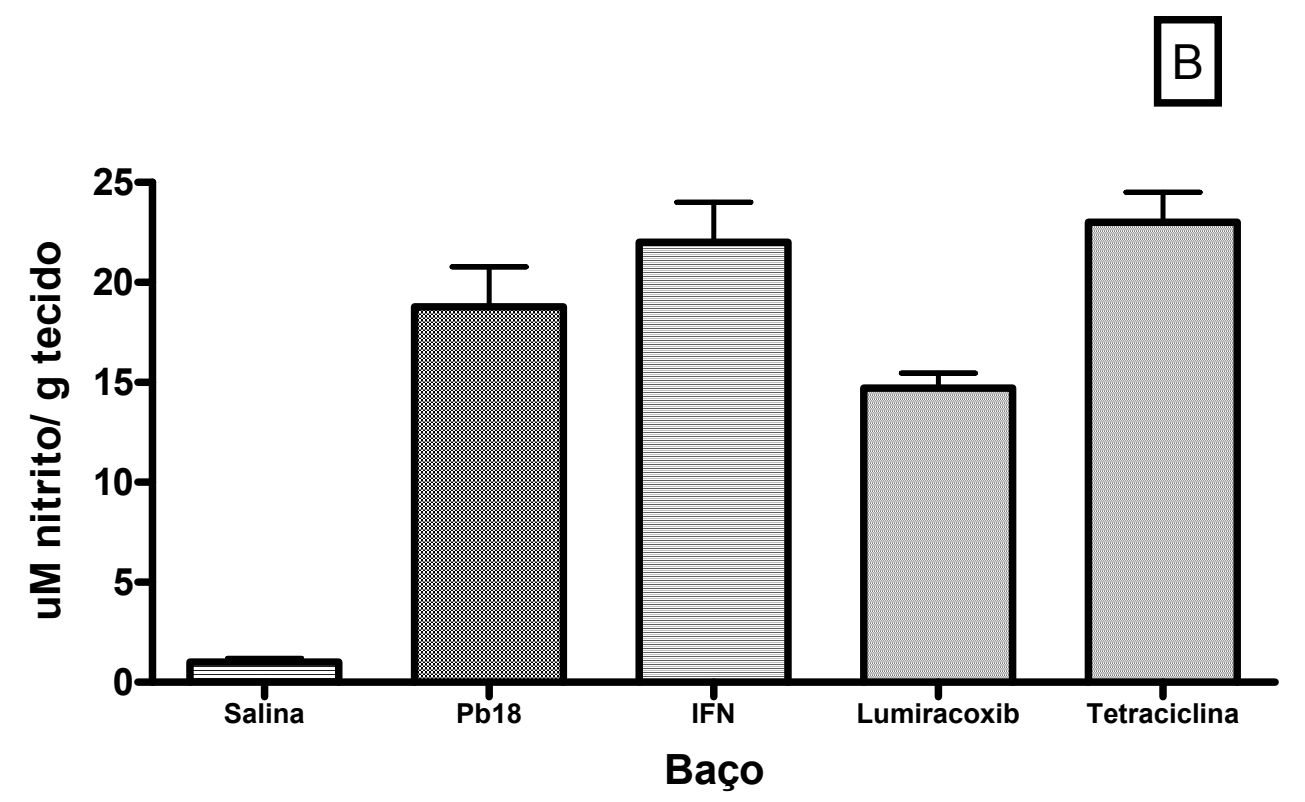

Figura 8 - Determinação da concentração de NO, mensurado sob a forma de nitrito, em camundongos B10.A inoculados com Pb18 e submetido a um dos tratamentos (IFN- $\gamma$; Tetraciclina; Lumiracoxib) ou apenas infectados, aos 120 dias de infecção. As barras representam o erro médio padrão.

* - Diferença estatística significativa com $p<0,05$ em relação aos controles apenas infectados. 

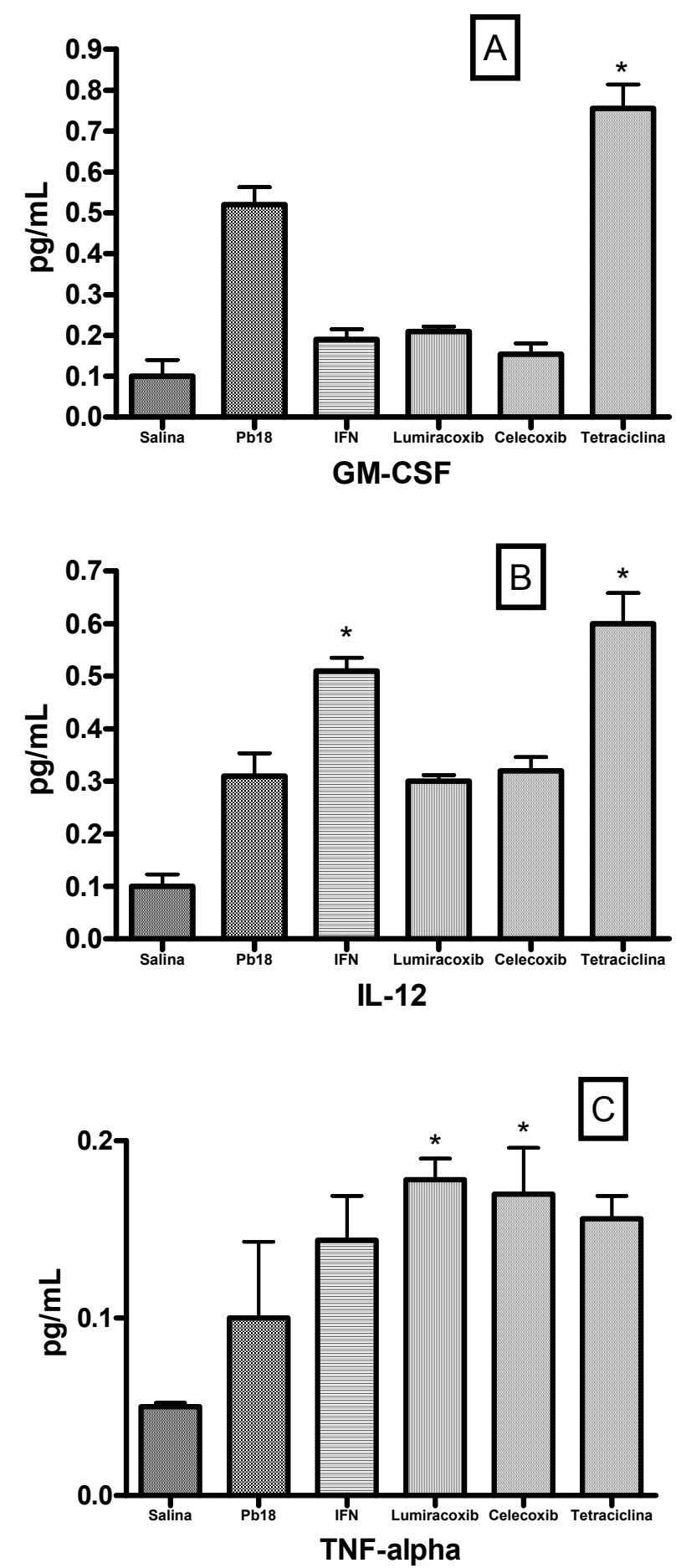

Figura 9 - Concentração das citocinas GM-CSF; TNF- $\alpha$ e IL-12 no epíplon de camundongos B10.A inoculados com Pb18 e submetido a um dos tratamentos (IFN- $\gamma$; Tetraciclina; Lumiracoxib; Celecoxib) ou apenas infectados, aos 15 dias de infecção. As barras representam o erro médio padrão.

* - Diferença estatística significativa com $p<0,05$ em relação aos controles apenas infectados. 

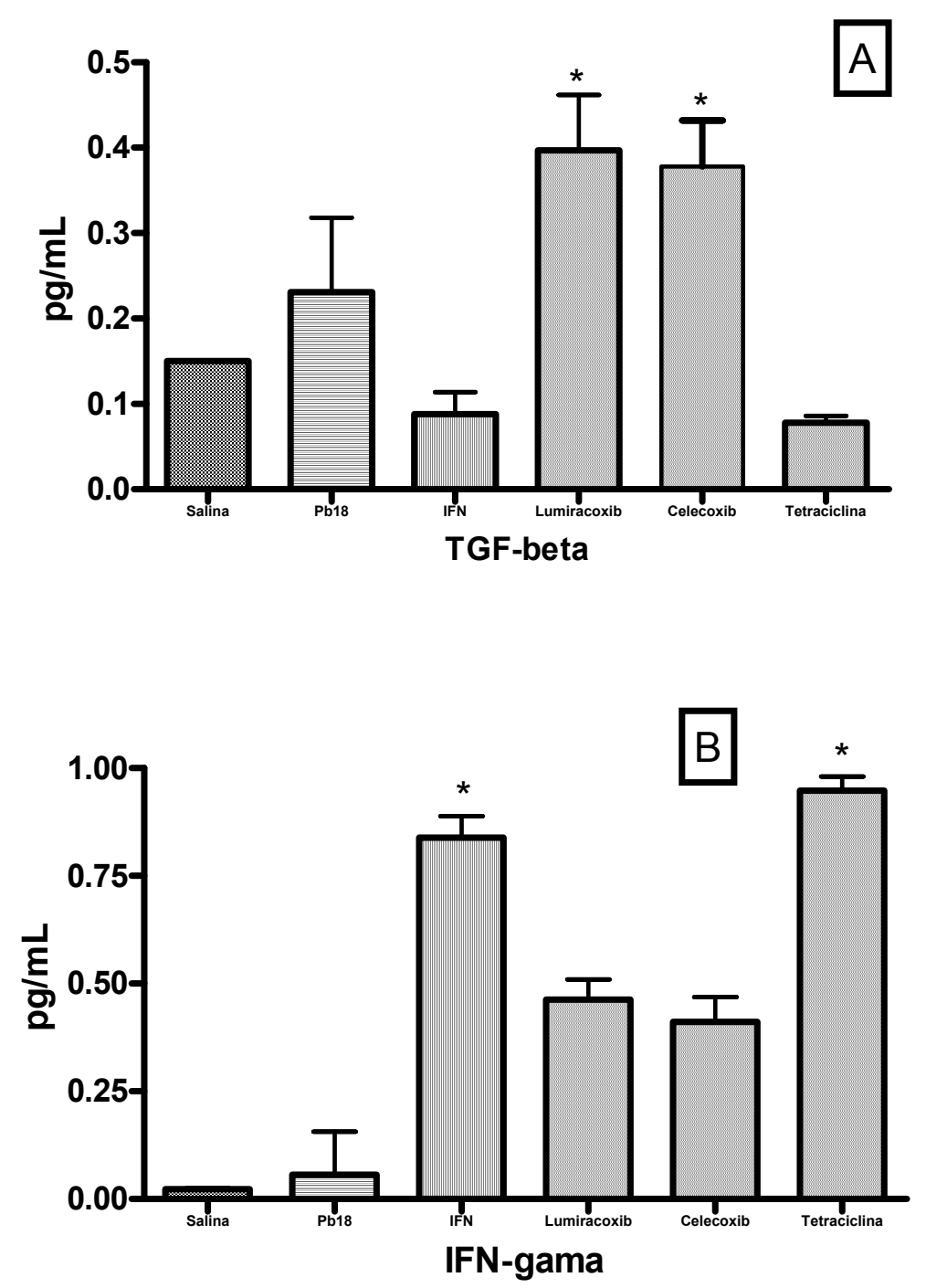

Figura 10 - Concentração das citocinas TGF- $\beta$ e IFN-Y no epíplon de camundongos B10.A inoculados com Pb18 e submetido a um dos tratamentos (IFN- $\gamma$; Tetraciclina; Lumiracoxib; Celecoxib) ou apenas infectados, aos 15 dias de infecção. As barras representam o erro médio padrão.

* - Diferença estatística significativa com $p<0,05$ em relação aos controles apenas infectados. 

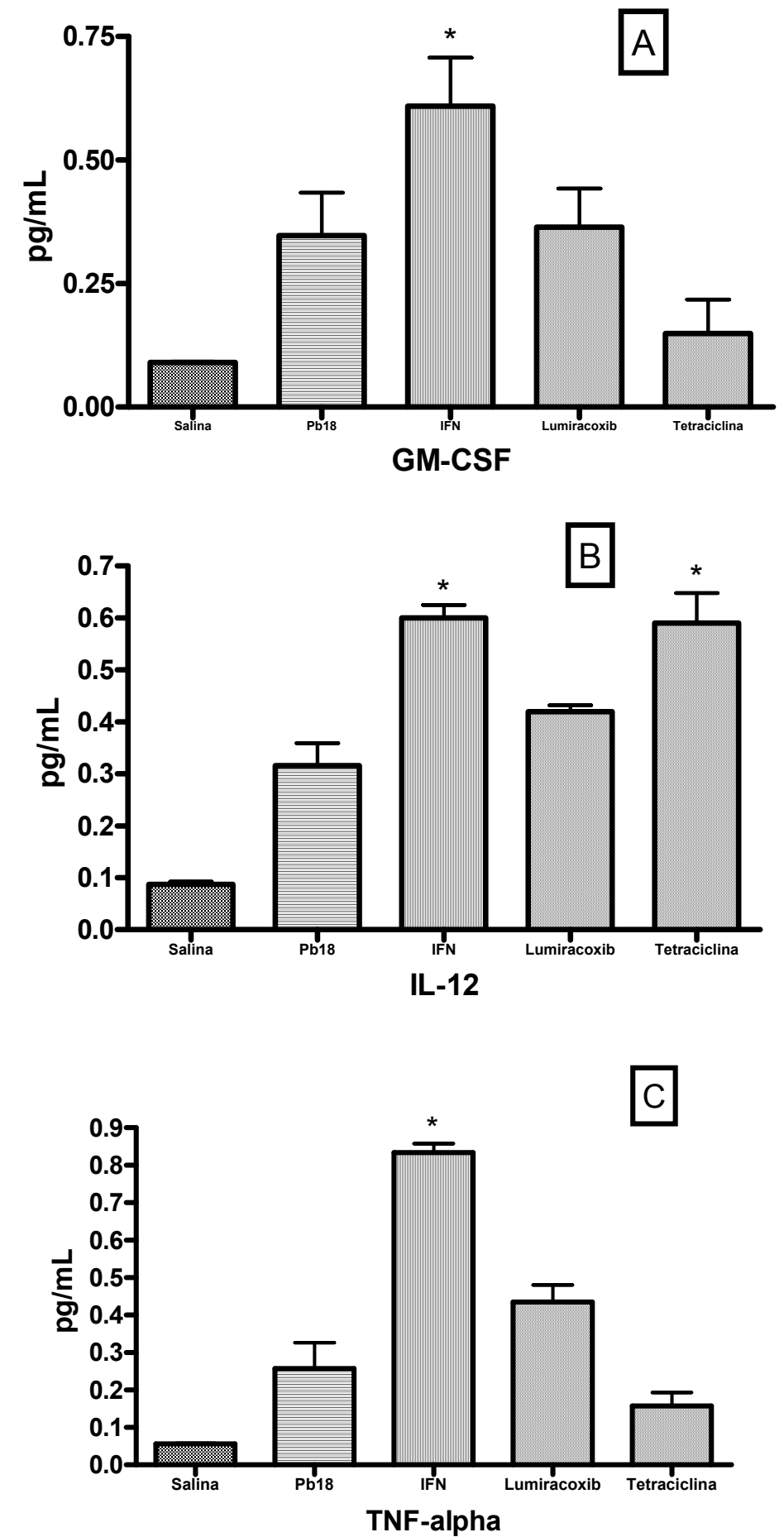

Figura 11 - Concentração das citocinas GM-CSF; TNF- $\alpha$ e IL-12 no epíplon de camundongos $\mathrm{B} 10 . \mathrm{A}$ inoculados com Pb18 e submetido a um dos tratamentos (IFN- $\gamma$; Tetraciclina; Lumiracoxib; Celecoxib) ou apenas infectados, aos 120 dias de infecção. As barras representam o erro médio padrão.

* - Diferença estatística significativa com $p<0,05$ em relação aos controles apenas infectados. 

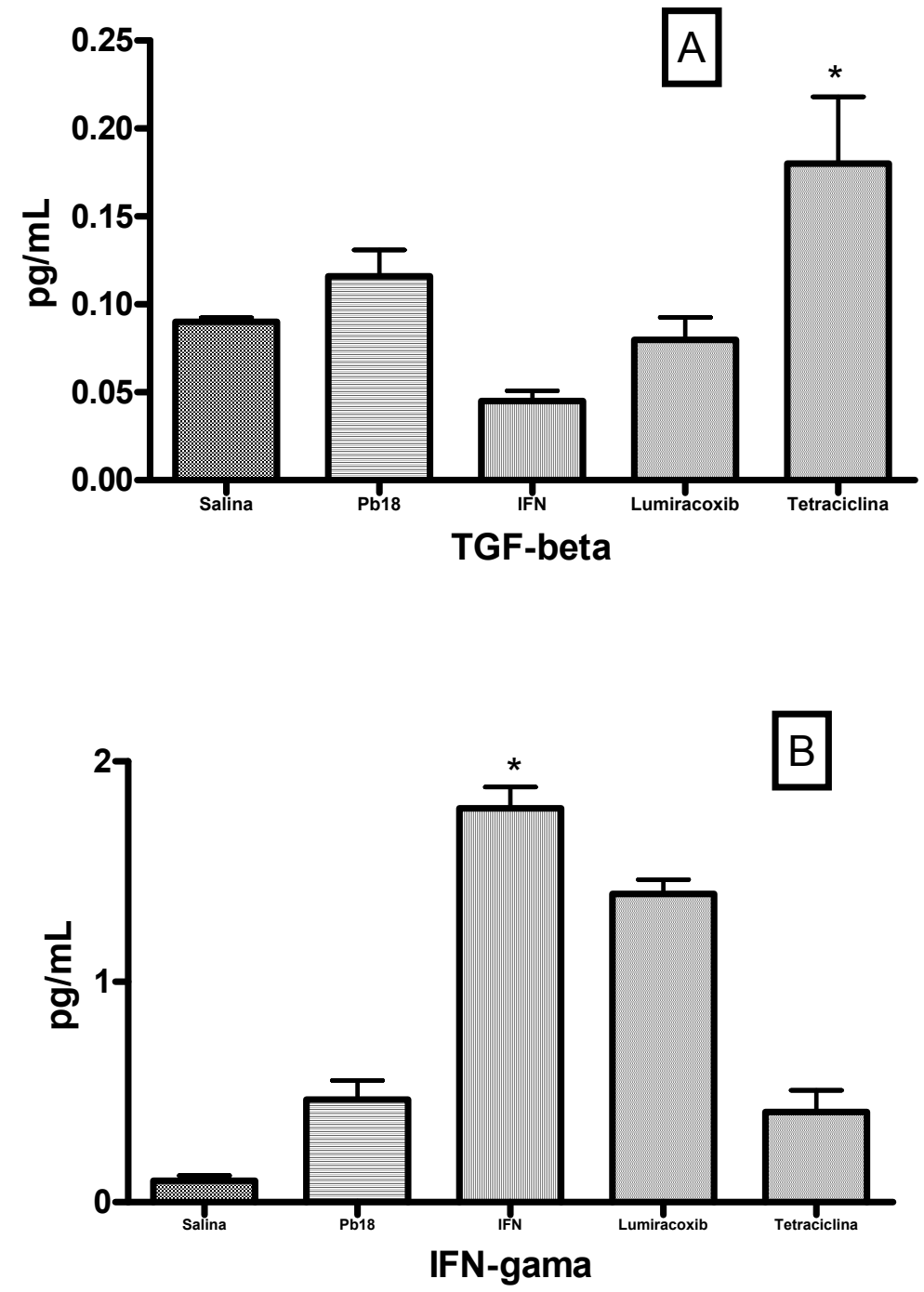

Figura 12 - Concentração das citocinas TGF- $\beta$ e IFN-Y no epíplon de camundongos B10.A inoculados com Pb18 e submetido a um dos tratamentos (IFN- $\gamma$; Tetraciclina; Lumiracoxib; Celecoxib) ou apenas infectados, aos 120 dias de infecção. As barras representam o erro médio padrão.

* - Diferença estatística significativa com $p<0,05$ em relação aos controles apenas infectados. 

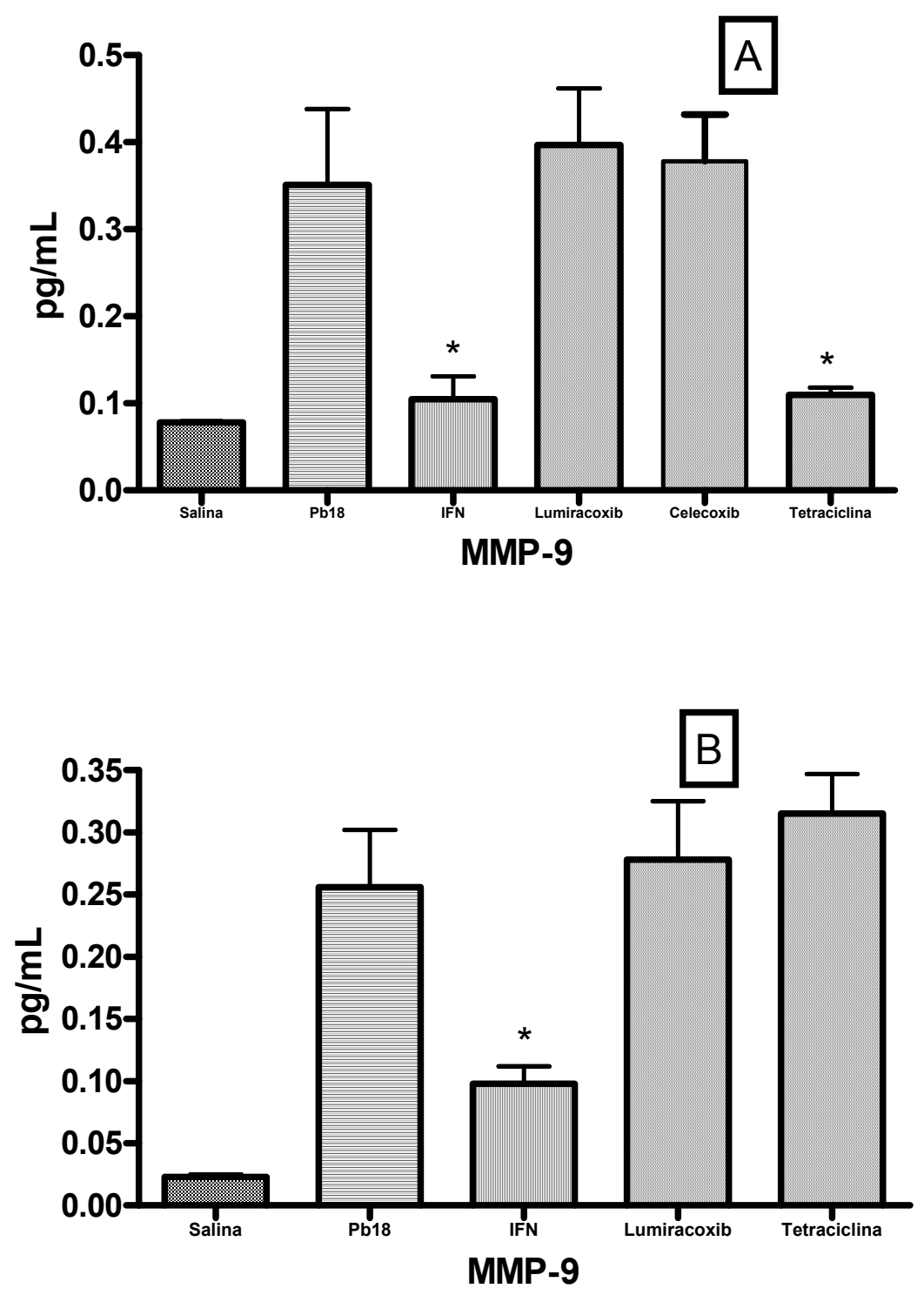

Figura 13 - Concentração de MMP-9 no epíplon de camundongos B10.A inoculados com Pb18 e submetido a um dos tratamentos (IFN- $\gamma$; Tetraciclina; Lumiracoxib; Celecoxib) ou apenas infectados, aos 15 (A) e 120 dias (B) de infecção. As barras representam o erro médio padrão.

* - Diferença estatística significativa com $p<0,05$ em relação aos controles apenas infectados. 

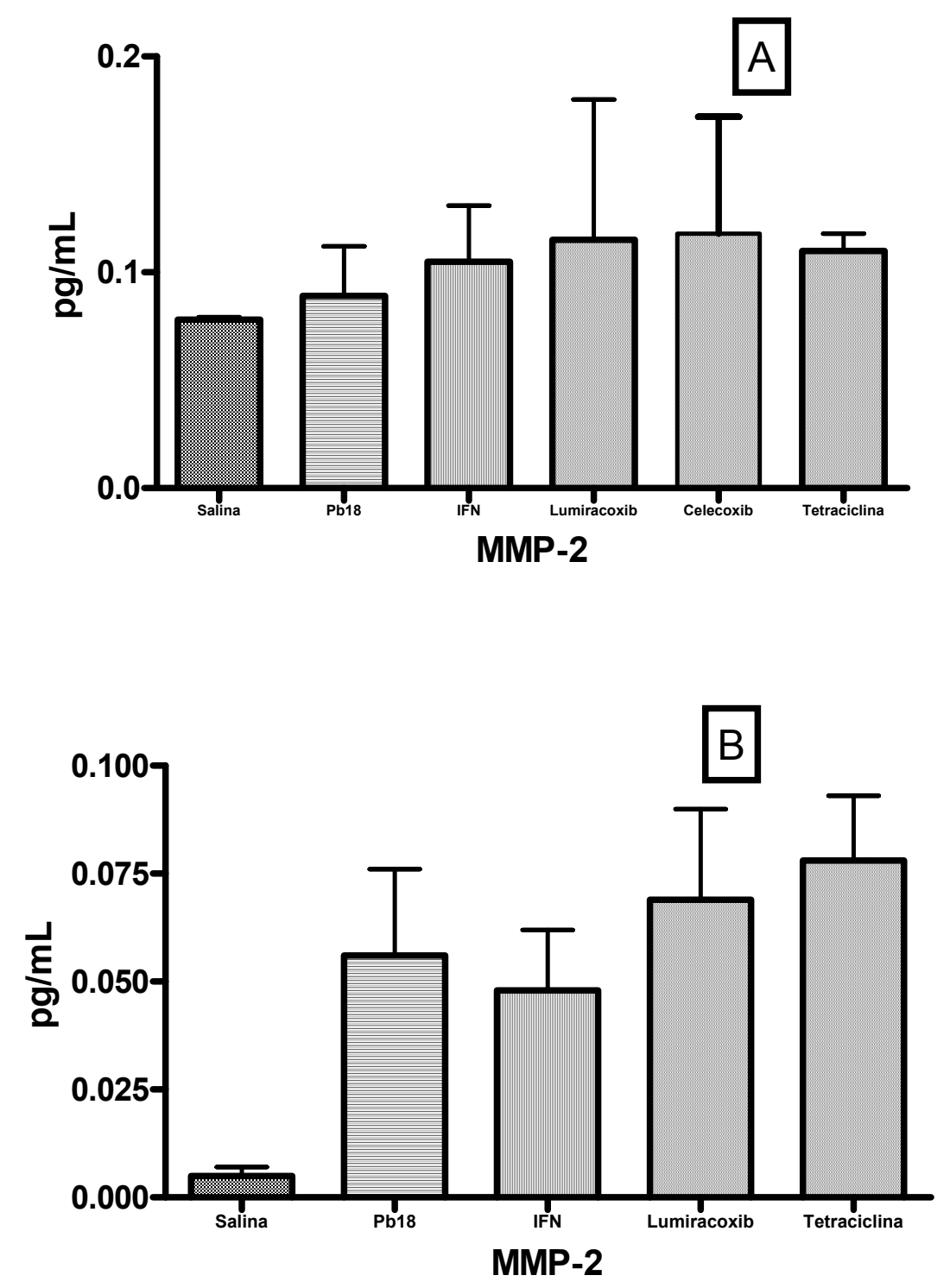

Figura 14 - Concentração de MMP-2 no epíplon de camundongos B10.A inoculados com Pb18 e submetido a um dos tratamentos (IFN- $\gamma$; Tetraciclina; Lumiracoxib; Celecoxib) ou apenas infectados, aos 15 (A) e 120 dias (B) de infecção. As barras representam o erro médio padrão. 


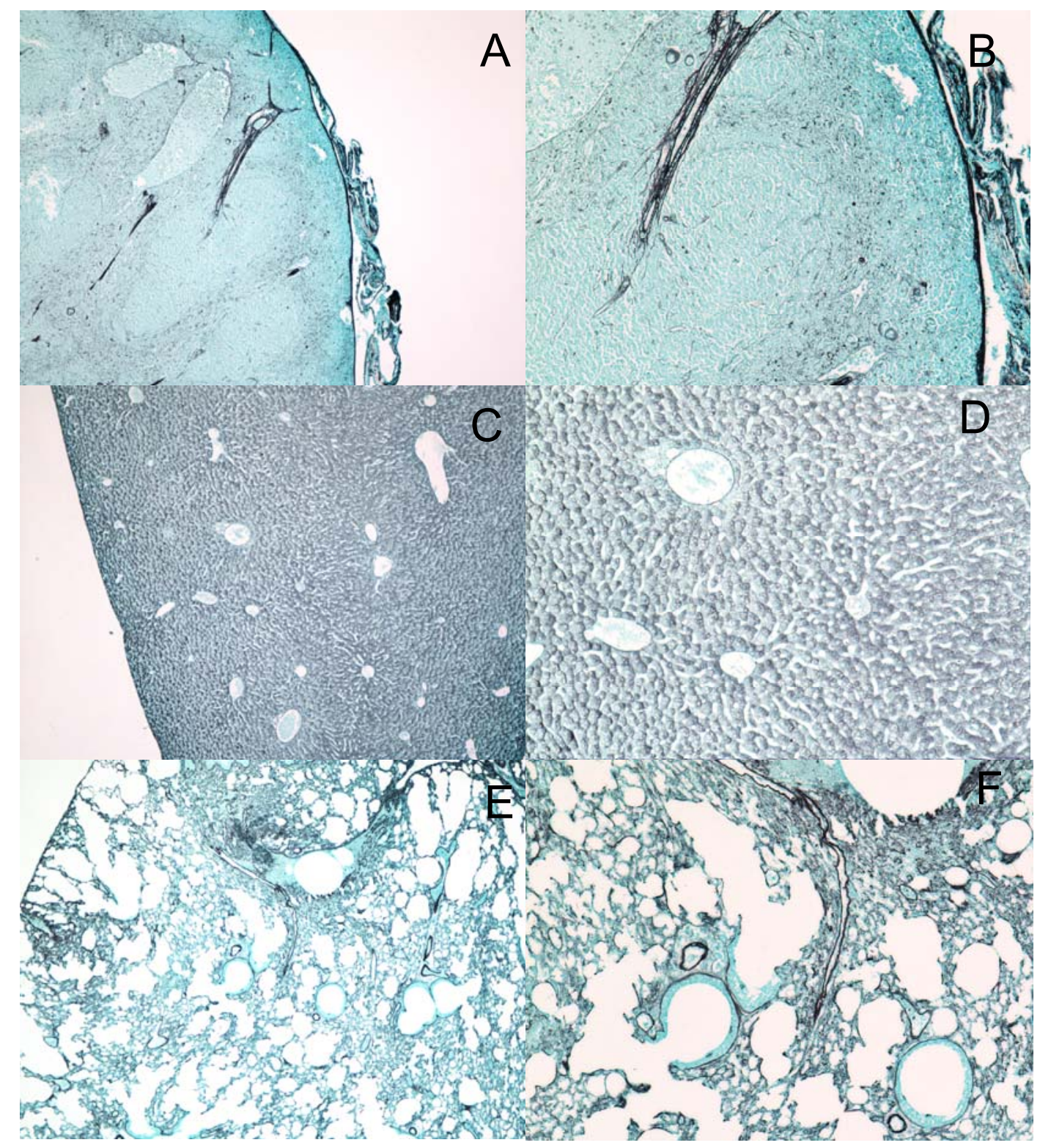

Prancha 1 - Análise quanto à presença de fungos em baço, fígado e pulmão através da coloração Grocott em camundongos apenas infectados, com 15 dias de infecção - Neste grupo de animais não conseguimos ver fungo nem no baço $(A-40 x)(B-100 x)$, nem no fígado $(C-40 x)(D-100 x)$ e nem no pulmão (E40x)(F-100x). 


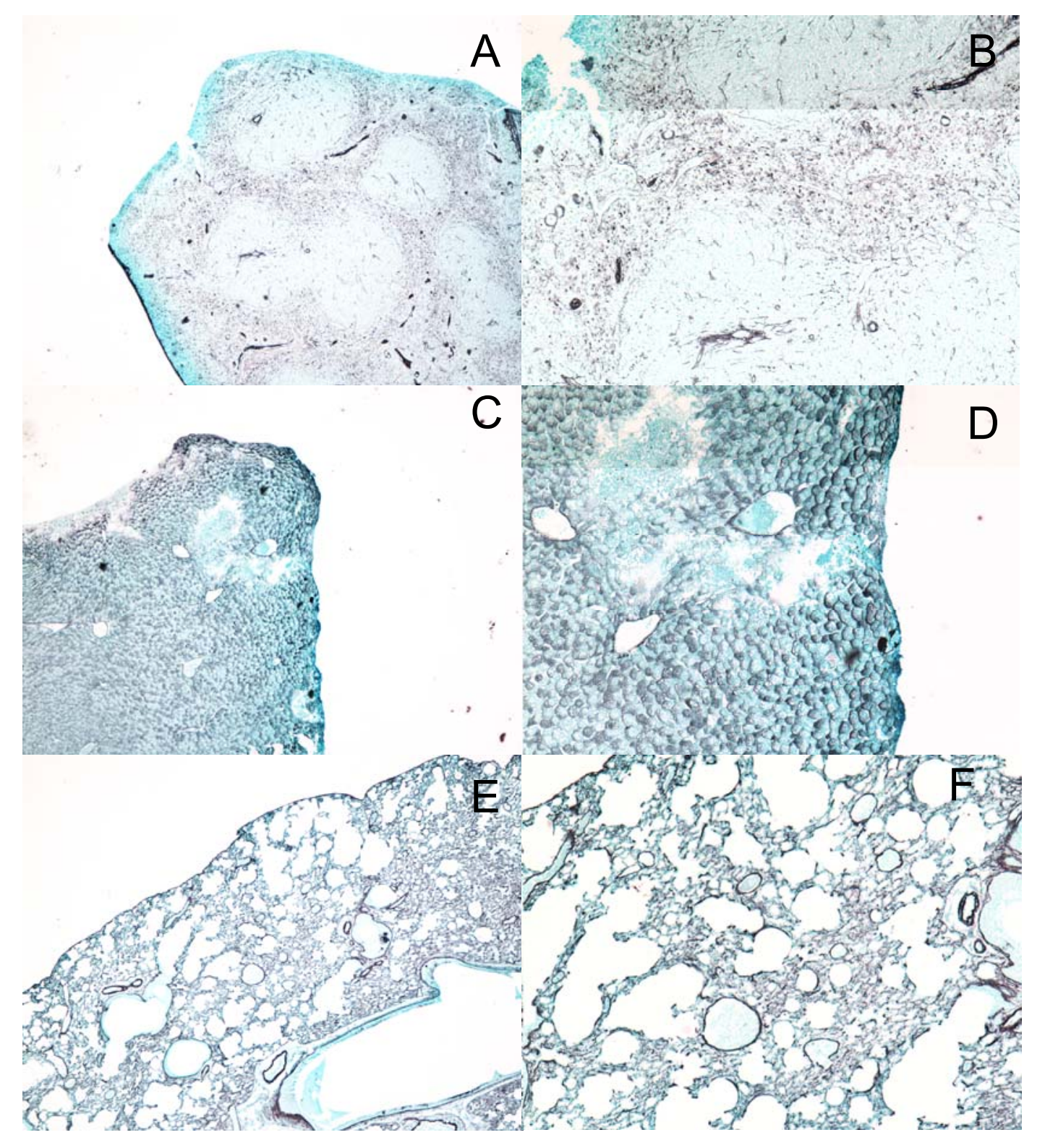

Prancha 2 - Análise quanto à presença de fungos em baço, fígado e pulmão através da coloração Grocott em camundongos infectados e tratados com IFN- $\gamma$ com 15 dias de infecção - Neste grupo de animais não conseguimos ver fungo nem no baço (A-40x)(B-100x), nem no fígado (C-40x)(D-100x) e nem no pulmão $(E-40 x)(f-100 x)$. 


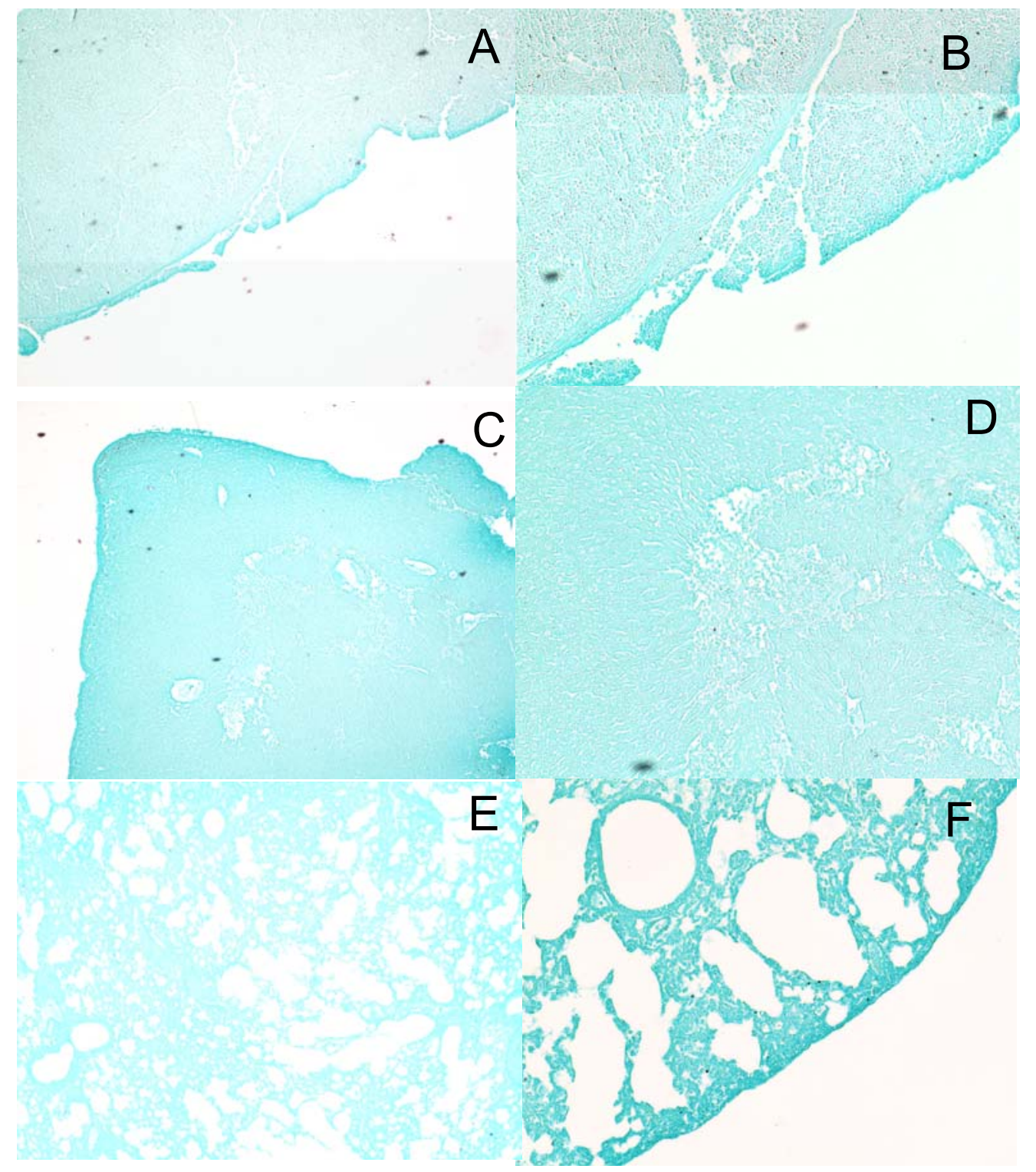

Prancha 3 - Análise quanto à presença de fungos em baço, fígado e pulmão através da coloração Grocott em camundongos infectados e tratados com Tetraciclina com 15 dias de infecção - Neste grupo de animais não conseguimos ver fungo nem no baço $(A-40 x)(B-100 x)$, nem no fígado (C40x)(D-100x) e nem no pulmão (E-40x)(f-100x). 


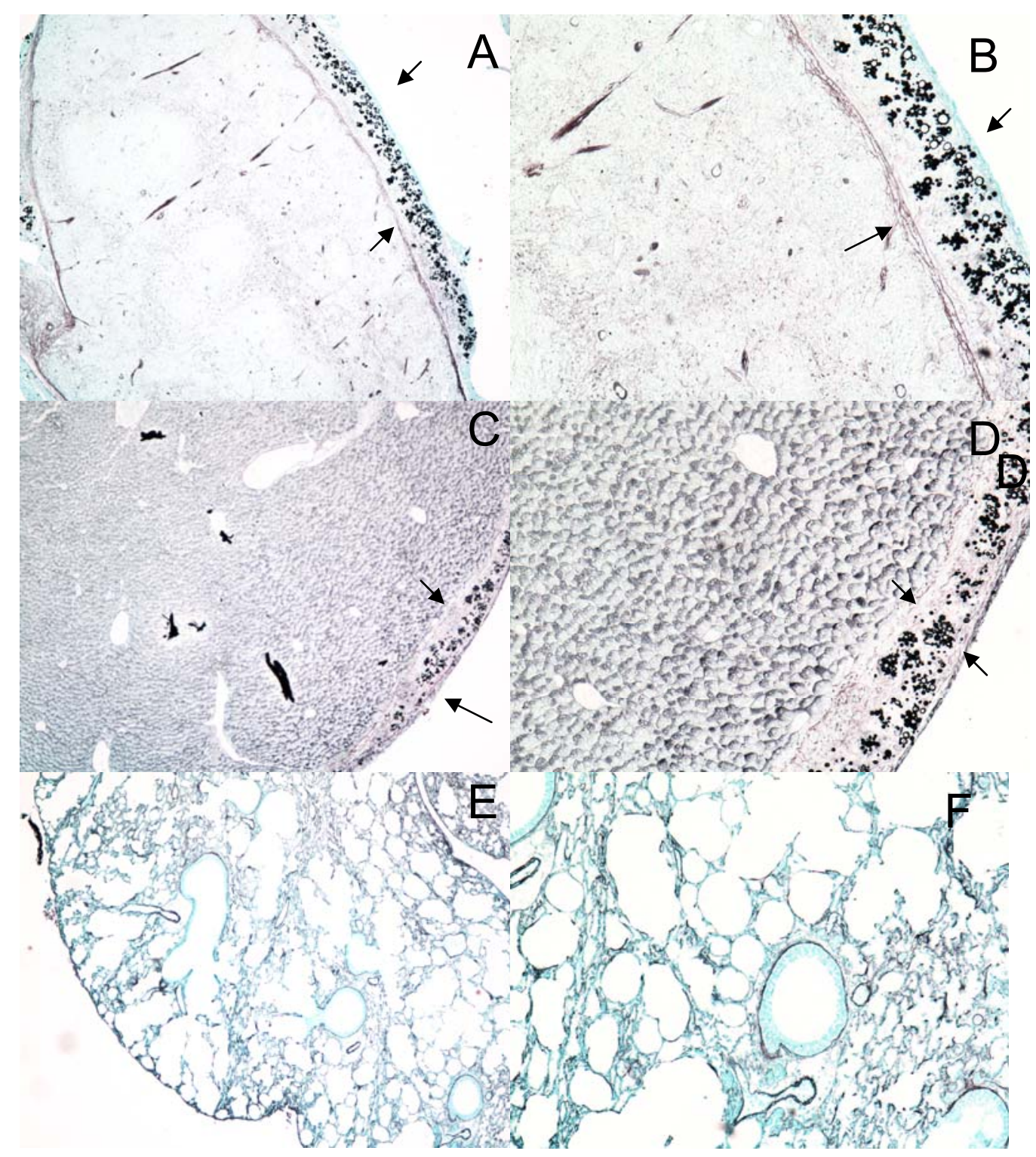

Prancha 4 - Análise quanto à presença de fungos em baço, fígado e pulmão através da coloração Grocott em camundongos infectados e tratados com Lumiracoxib com 15 dias de infecção - Este grupo de animais apresentaram intensa população fúngica com a morfologia típica no tecido que reveste o baço $(A-40 x)(B-100 x)$ e o fígado $(C-40 x)(100 x)$, no pulmão não foi visto célula fúngica $(\mathrm{E}-40 \mathrm{x})(\mathrm{F}-100 \mathrm{x})$. 

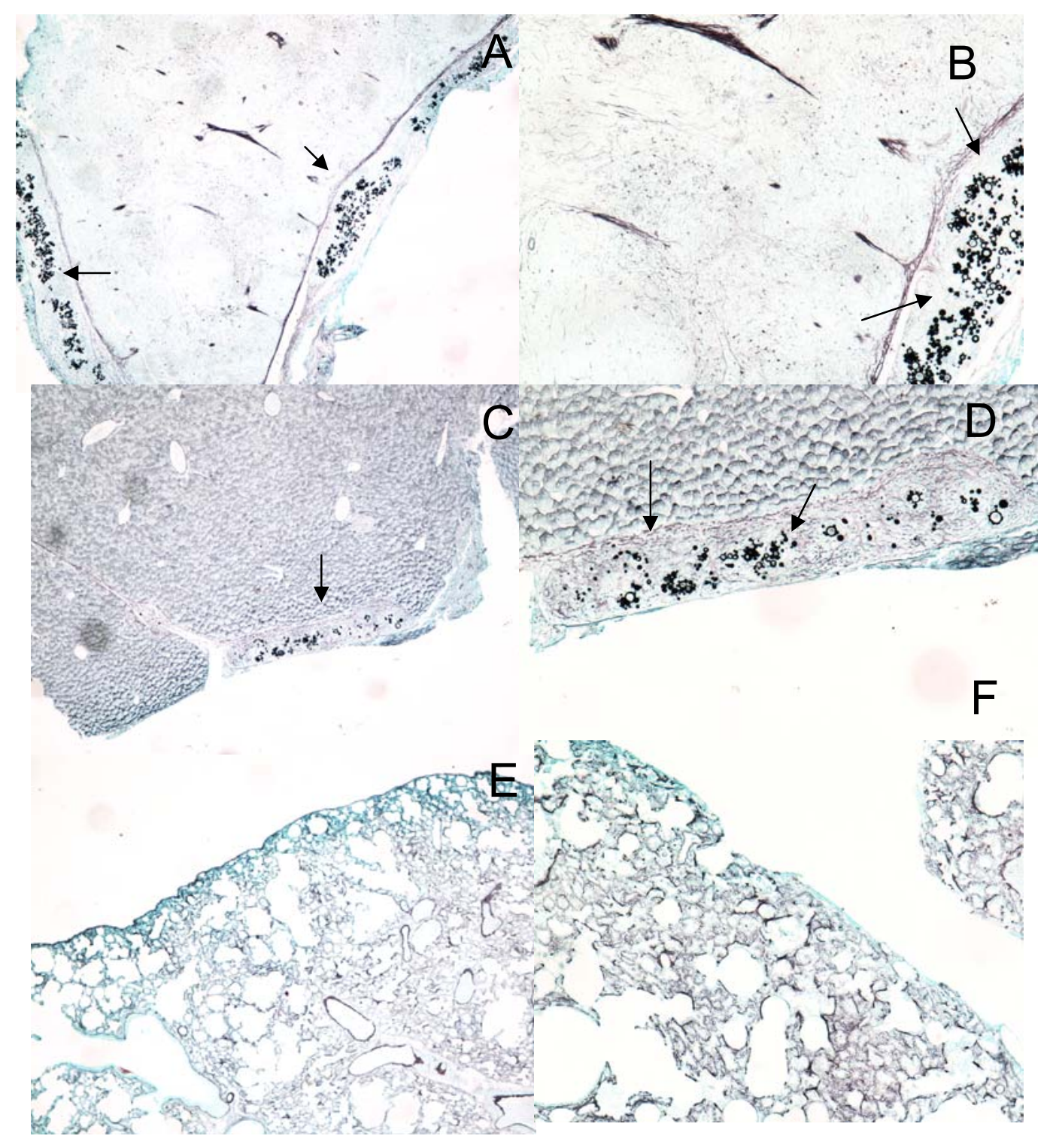

Prancha 5 - Análise quanto à presença de fungos em baço, fígado e pulmão através da coloração Grocott em camundongos infectados e tratados com Celecoxib com 15 dias de infecção - Este grupo de animais apresentaram intensa população fúngica com a morfologia típica no tecido que reveste 0 baço $(A-40 x)(B-100 x)$ e o fígado $(C-40 x)(100 x)$, no pulmão não foi visto célula fúngica $(\mathrm{E}-40 \mathrm{x})(\mathrm{F}-100 \mathrm{x})$. 


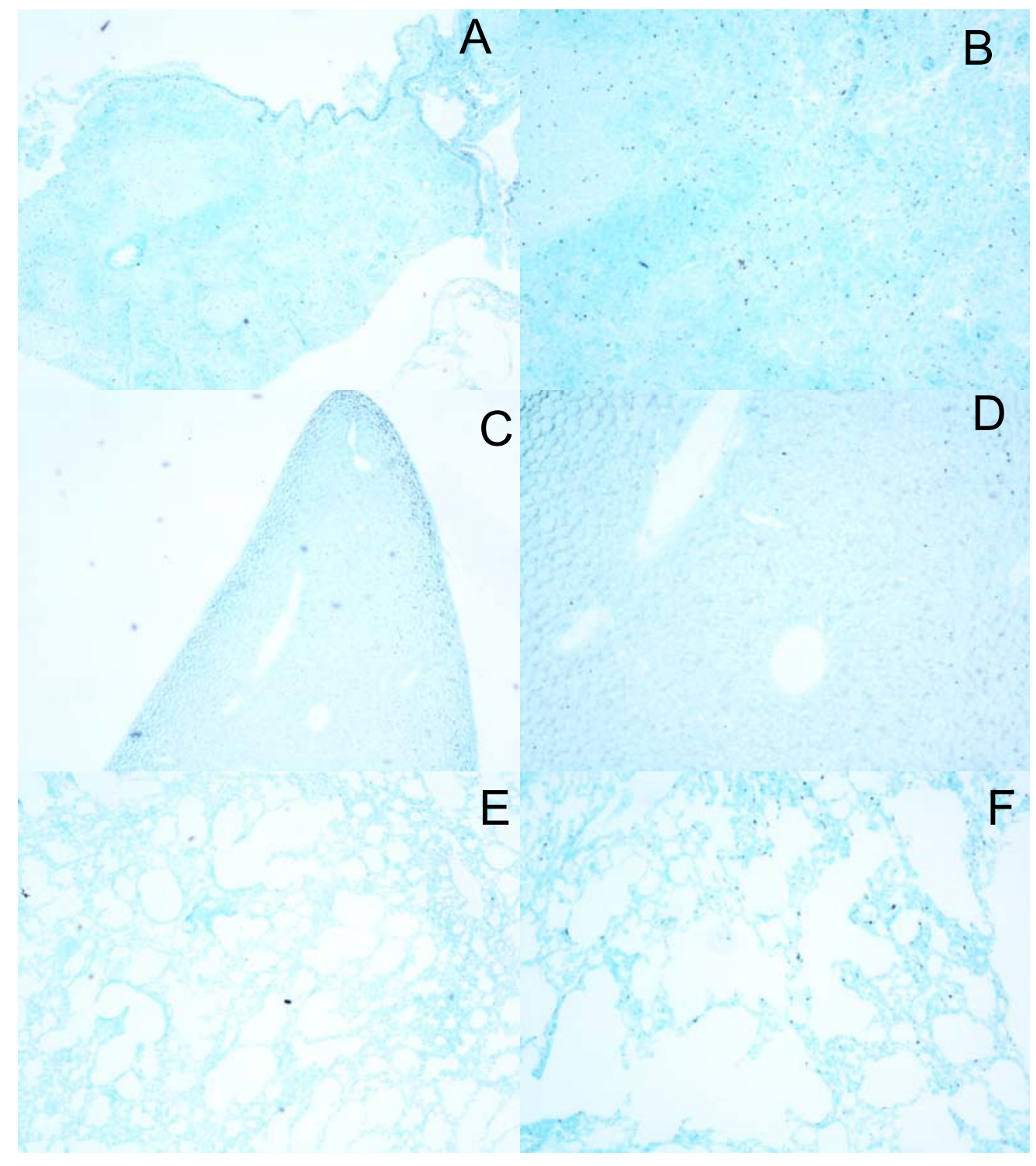

Prancha 6 - Análise quanto à presença de fungos em baço, fígado e pulmão através da coloração Grocott em camundongos apenas infectados, com 120 dias de infecção - Neste grupo de animais não conseguimos ver fungo nem no baço $(A-40 x)(B-100 x)$, nem no fígado $(C-40 x)(D-100 x)$ e nem no pulmão (E40x)(F-100x). 
Prancha 7 - Análise quanto à presença de fungos em baço, fígado e pulmão através da coloração Grocott em camundongos infectados e tratados com IFN- $\gamma$ com 120 dias de infecção - Neste grupo de animais não conseguimos ver fungo nem no baço (A-40x)(B-100x), nem no fígado (C-40x)(D-100x) e nem no pulmão (E-40x)(f-100x). 
Prancha 8 - Análise quanto à presença de fungos em baço, fígado e pulmão através da coloração Grocott em camundongos infectados e tratados com Tetraciclina com 15 dias de infecção - Neste grupo de animais não conseguimos ver fungo nem no baço $(A-40 x)(B-100 x)$, nem no fígado (C40x)(D-100x) e nem no pulmão (E-40x)(f-100x). 


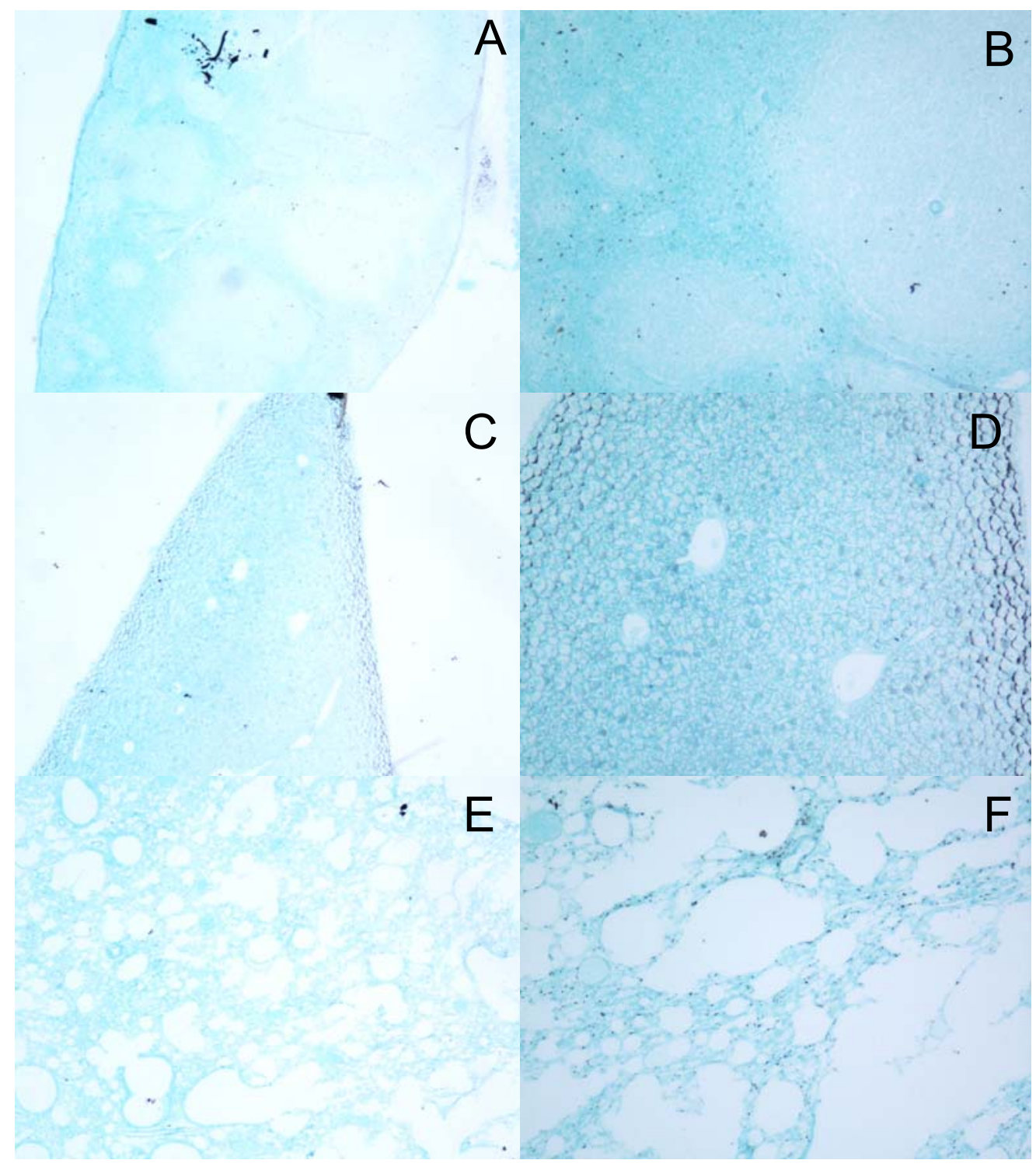

Prancha 9 - Análise quanto à presença de fungos em baço, fígado e pulmão através da coloração Grocott em camundongos infectados e tratados com Lumiracoxib com 120 dias de infecção - Este grupo de animais apresentaram intensa população fúngica com a morfologia típica no tecido que reveste o baço $(A-40 x)(B-100 x)$ e o fígado $(C-40 x)(100 x)$, no pulmão não foi visto célula fúngica $(E-40 x)(F-100 x)$. 


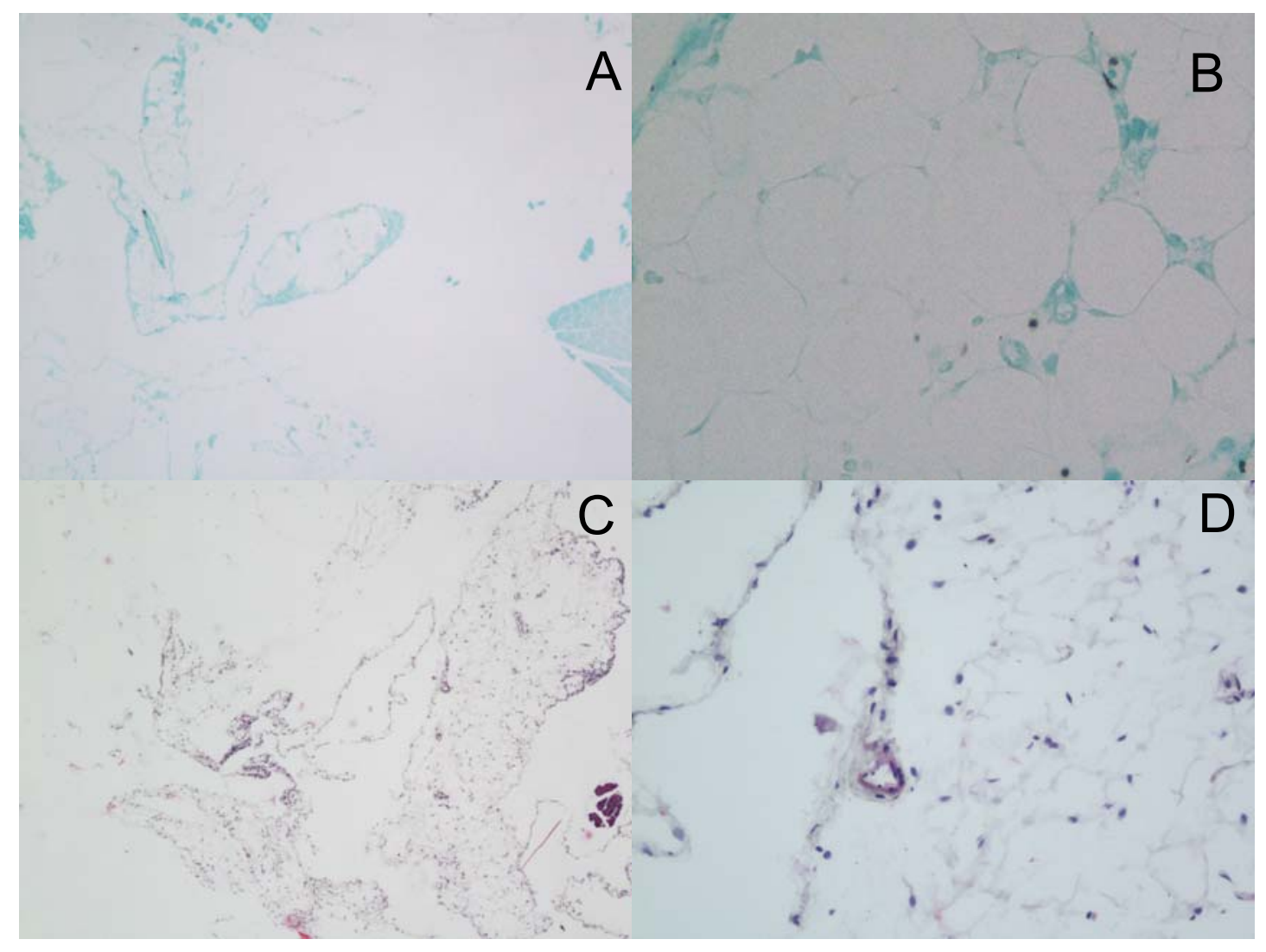

Prancha 10 - Avaliação da disseminação fúngica, aspecto do granuloma e celularidade presente no epíplon através da coloração de Grocott e HE em animais sem infecção - Os animais não apresentam presença alguma de fungos (A-40x) (B-400x). Esses animais não possuem lesão (C-40x) e nem células inflamatórias (D-200x). 


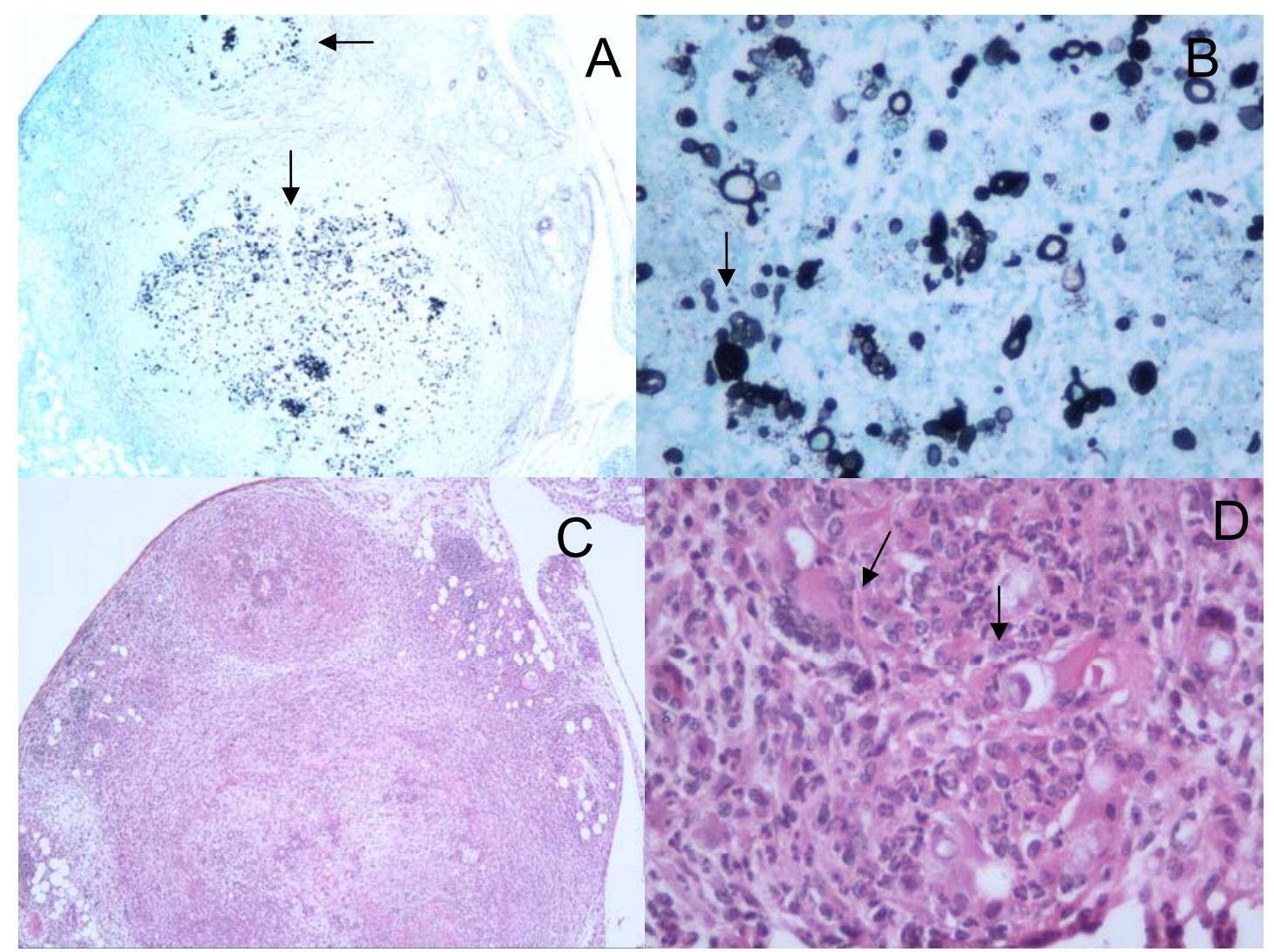

Prancha 11 - Avaliação da disseminação fúngica, aspecto do granuloma e celularidade presente no epíplon através da coloração de Grocott e HE em animais apenas infectados, aos 15 dias de infecção - Os animais apenas infectados apresentaram grande foco fúngico com uma discreta disseminação (A-40x) a morfologia desse fungo era quase que totalmente típica (B-400x). Esses animais apresentaram um granuloma com aspecto frouxo (C-40x) e presença de células gigantes multinucleadas (D-400x). 


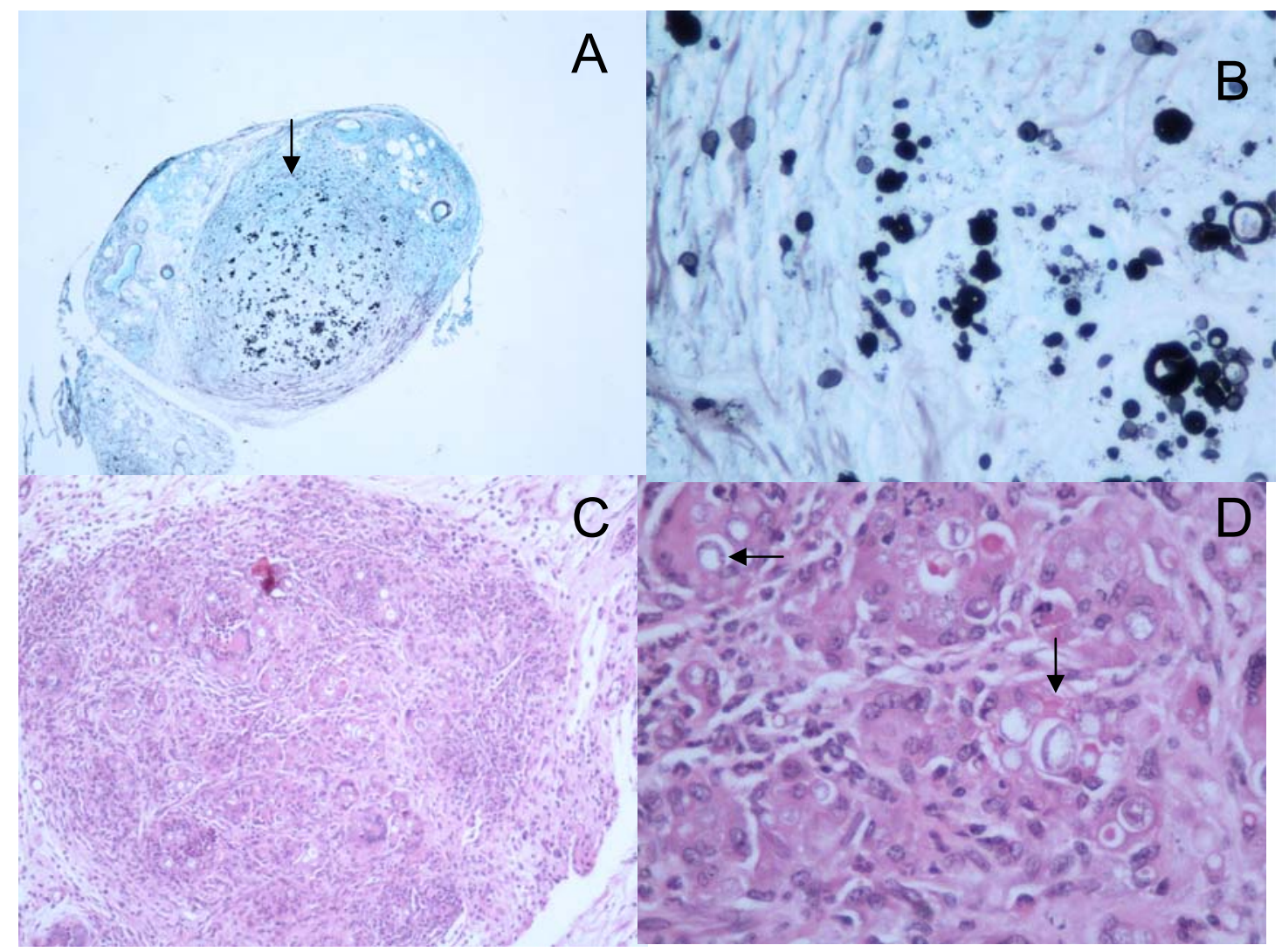

Prancha 12 - Avaliação da disseminação fúngica, aspecto do granuloma e celularidade presente no epíplon através da coloração de Grocott e $\mathrm{HE}$ em camundongos infectados e tratados com IFN- $\gamma$, aos 15 dias de infecção - Os animais infectados e tratados com IFN- $\gamma$ apresentaram foco fúngico bem centralizado (A-40x) com a morfologia que variava de típico para atípico (B-400x). Houve a formação de um granuloma compacto $(\mathrm{C}-40 \mathrm{x})$ e a presença de grande número de células inflamatórias (D-400x). 


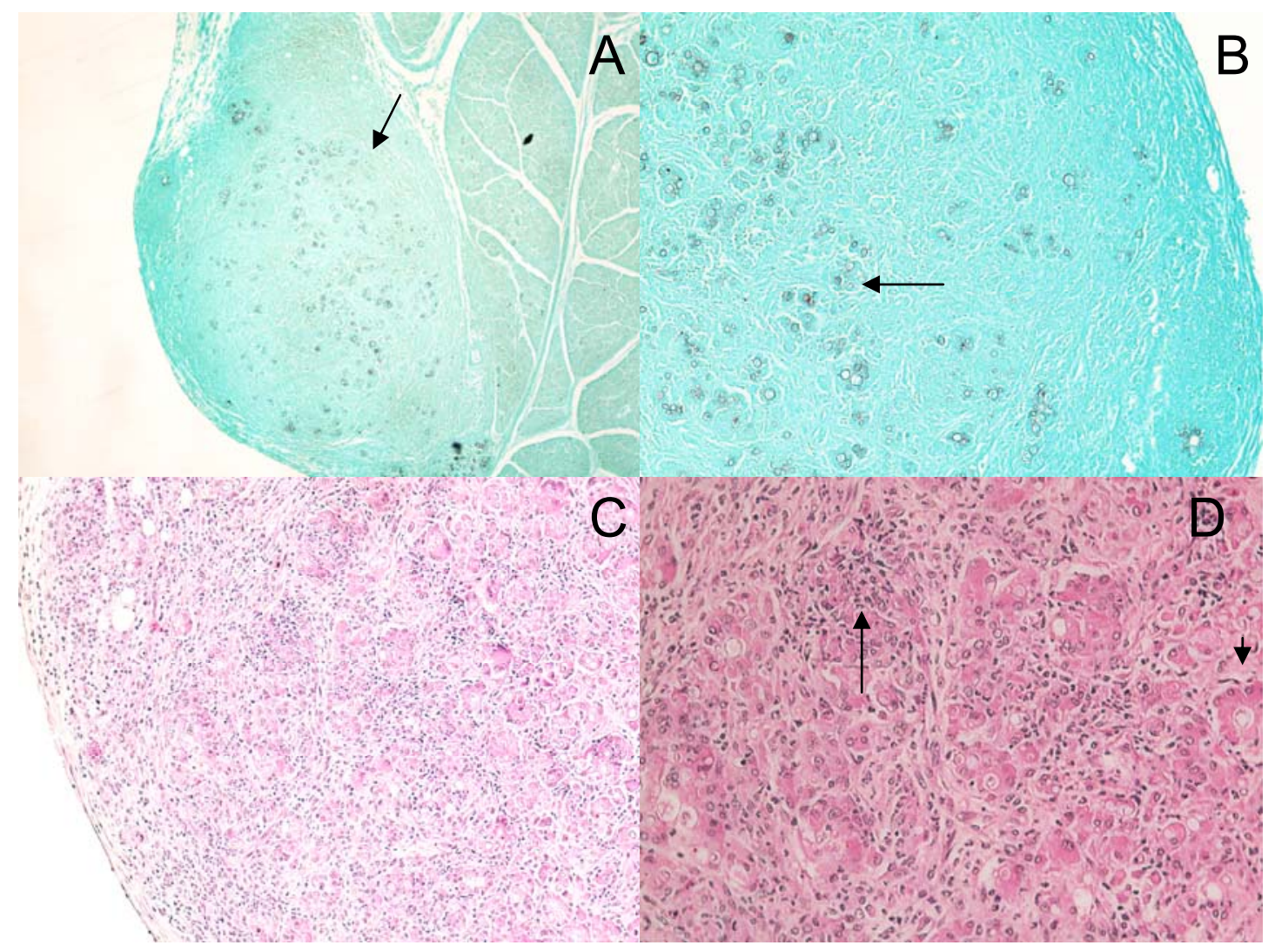

Prancha 13 - Avaliação da disseminação fúngica, aspecto do granuloma e celularidade presente no epíplon através da coloração de Grocott e HE em animais infectados e tratados com Tetraciclina, aos 15 dias de infecção - Os animais infectados e tratados com tetraciclina apresentaram pequeno número de fungos dispersos pelo tecido (A-40x) porém com a maioria apresentando uma morfologia atípica (B-400x). Não houve formação de granuloma (C-40x) nem presença de células gigantes (D-400x). 


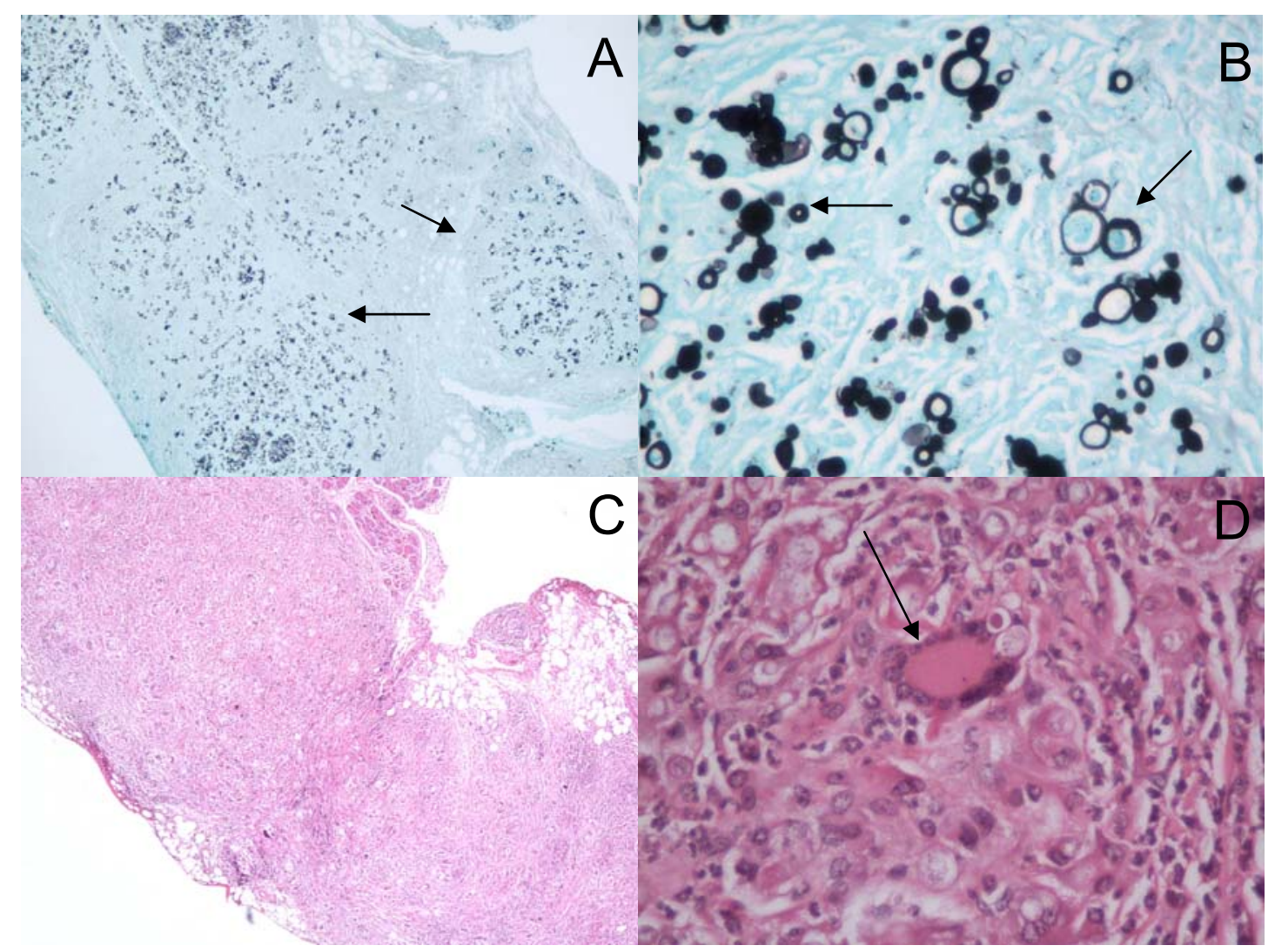

Prancha 14 - Avaliação da disseminação fúngica, aspecto do granuloma e celularidade presente no epíplon através da coloração de Grocott e HE em animais infectados e tratados com Lumiracoxib, aos 15 dias de infecção - Os animais com lumiracoxib apresentaram intensa disseminação fúngica (A-40x) com sua morfologia típica (B-400x). Houve uma deposição absurda de colágeno $(\mathrm{C}-40 \mathrm{x})$ e a presença de células gigantes multinucleadas que chegavam a ter 16 núcleos (D-400x). 


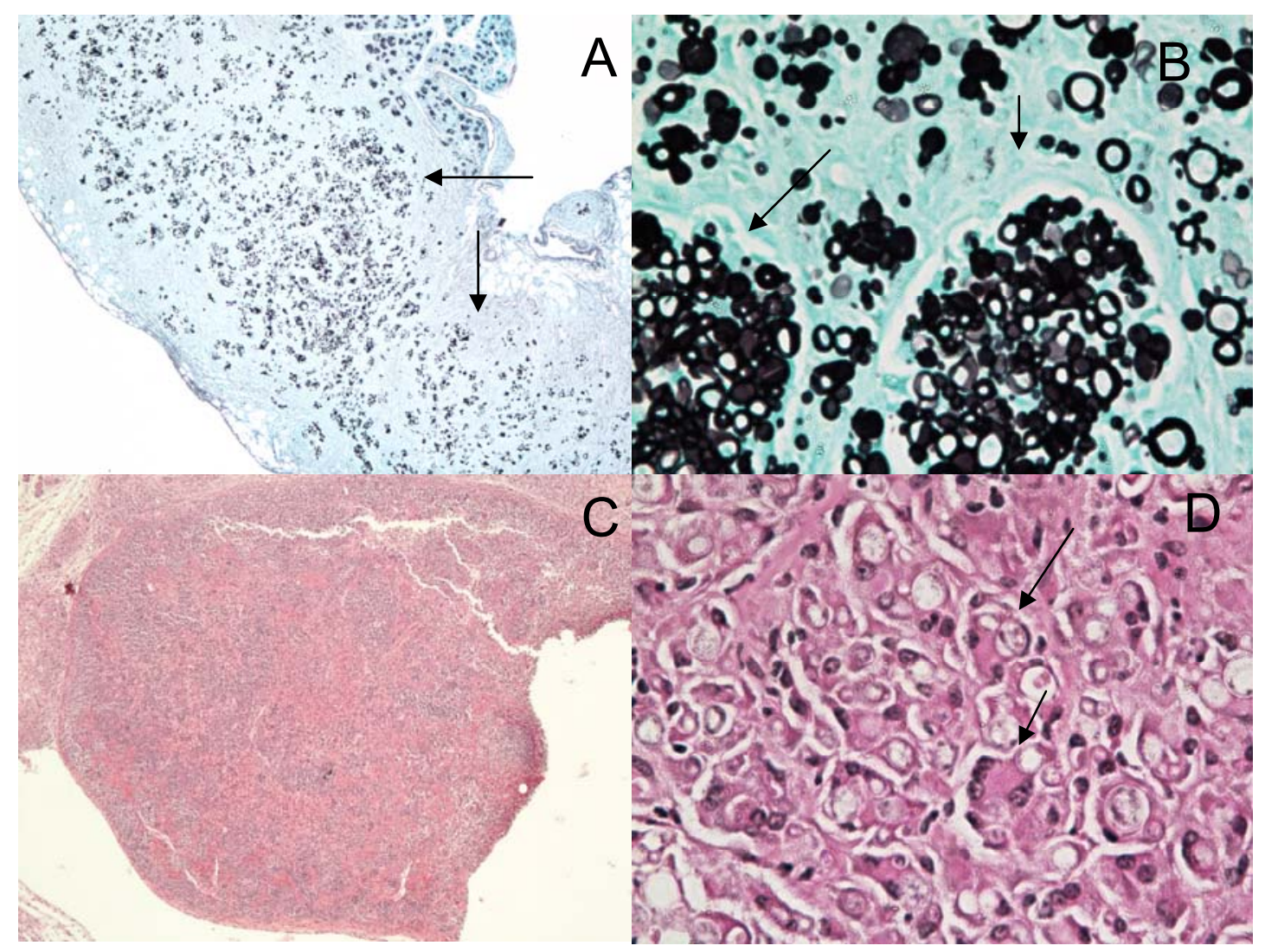

Prancha 15 - Avaliação da disseminação fúngica, aspecto do granuloma e celularidade presente no epíplon através da coloração de Grocott e HE em animais infectados e tratados com Celecoxib, aos 15 dias de infecção -Os animais infectados e tratados com celecoxib apresentaram intensa disseminação fúngica (A-40x) com sua morfologia típica (B-400x). Houve uma deposição absurda de colágeno (C-40x) e a presença de células gigantes multinucleadas que chegavam a ter 16 núcleos (D-400x). 


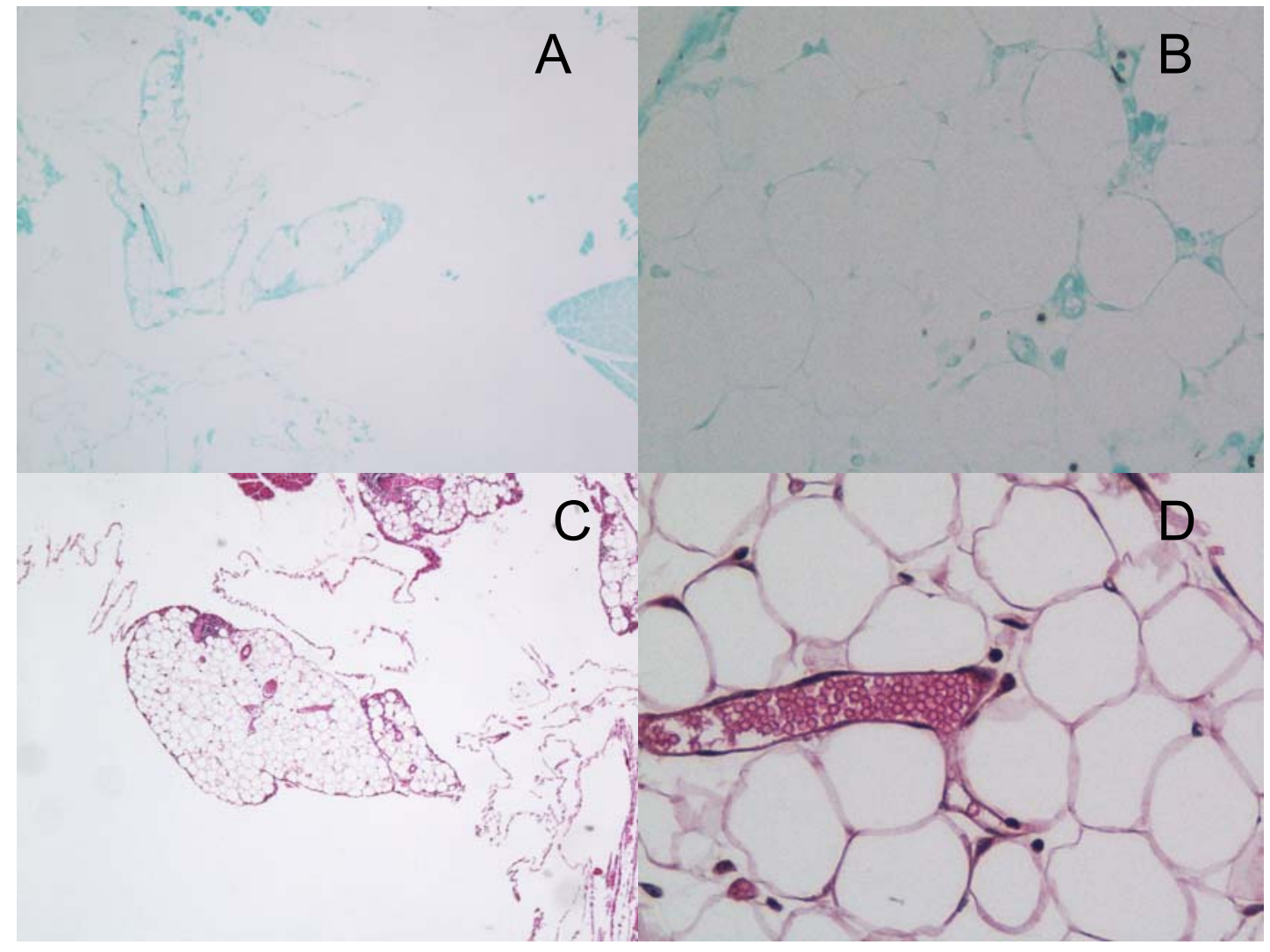

Prancha 16 - Avaliação da disseminação fúngica, aspecto do granuloma e celularidade presente no epíplon através da coloração de Grocott e HE em animais infectados com salina, aos 120 dias de infecção - Os animais não apresentam fungo algum (A-40x) (B-400x). Esses animais possuem um epíplon pouco desenvolvido, sem células inflamatórias (C40x) (D-400x). 


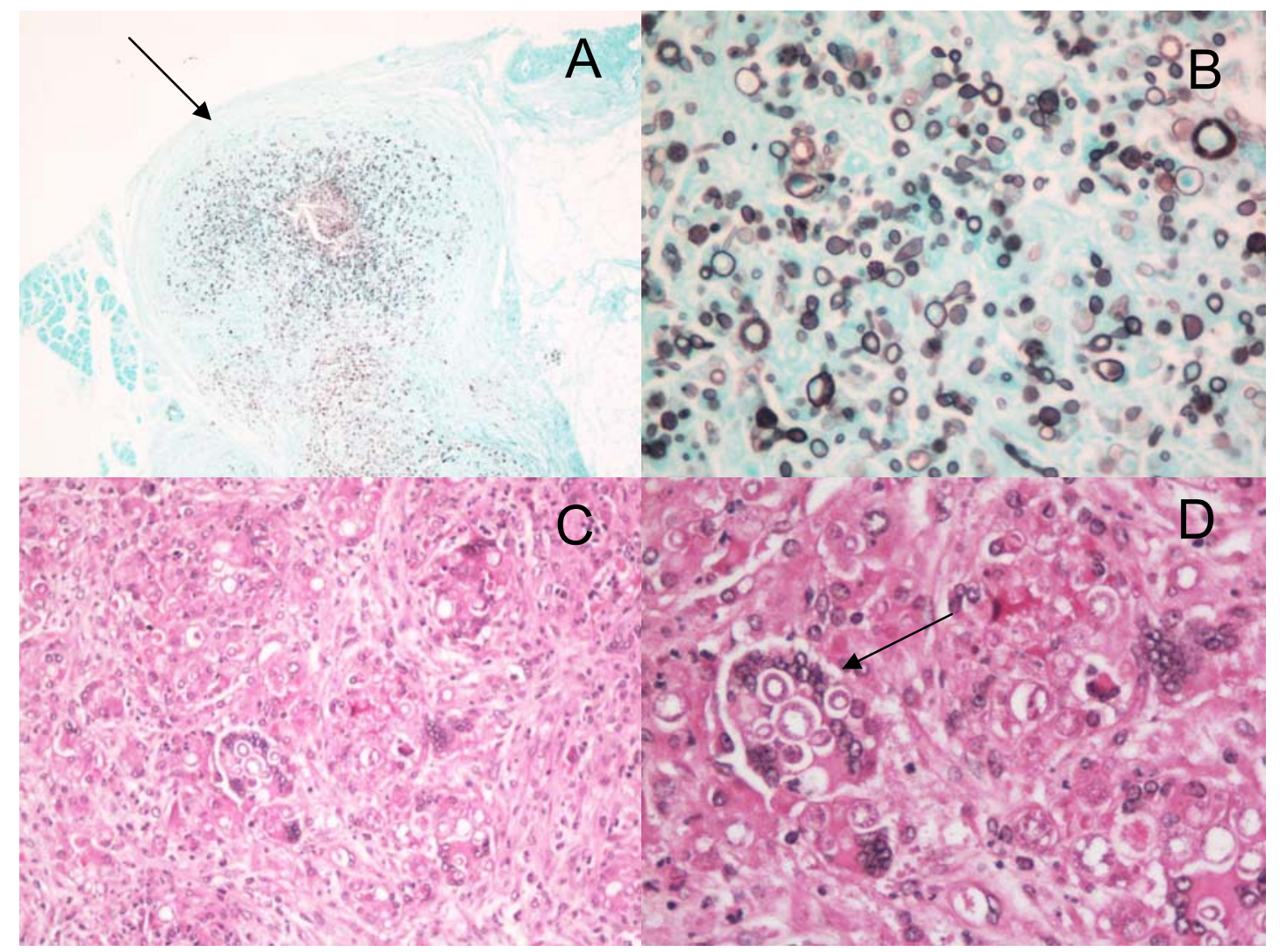

Prancha 17 - Avaliação da disseminação fúngica, aspecto do granuloma e celularidade presente no epíplon através da coloração de Grocott e HE em animais apenas infectados, aos 120 dias de infecção - Os animais apenas infectados apresentaram grande foco fúngico com uma intensa disseminação (A-40x) a morfologia desse fungo era quase que totalmente típica (B-400x). Esses animais apresentaram um granuloma com aspecto frouxo (C-40x) e presença de células gigantes multinucleadas (D-400x). 


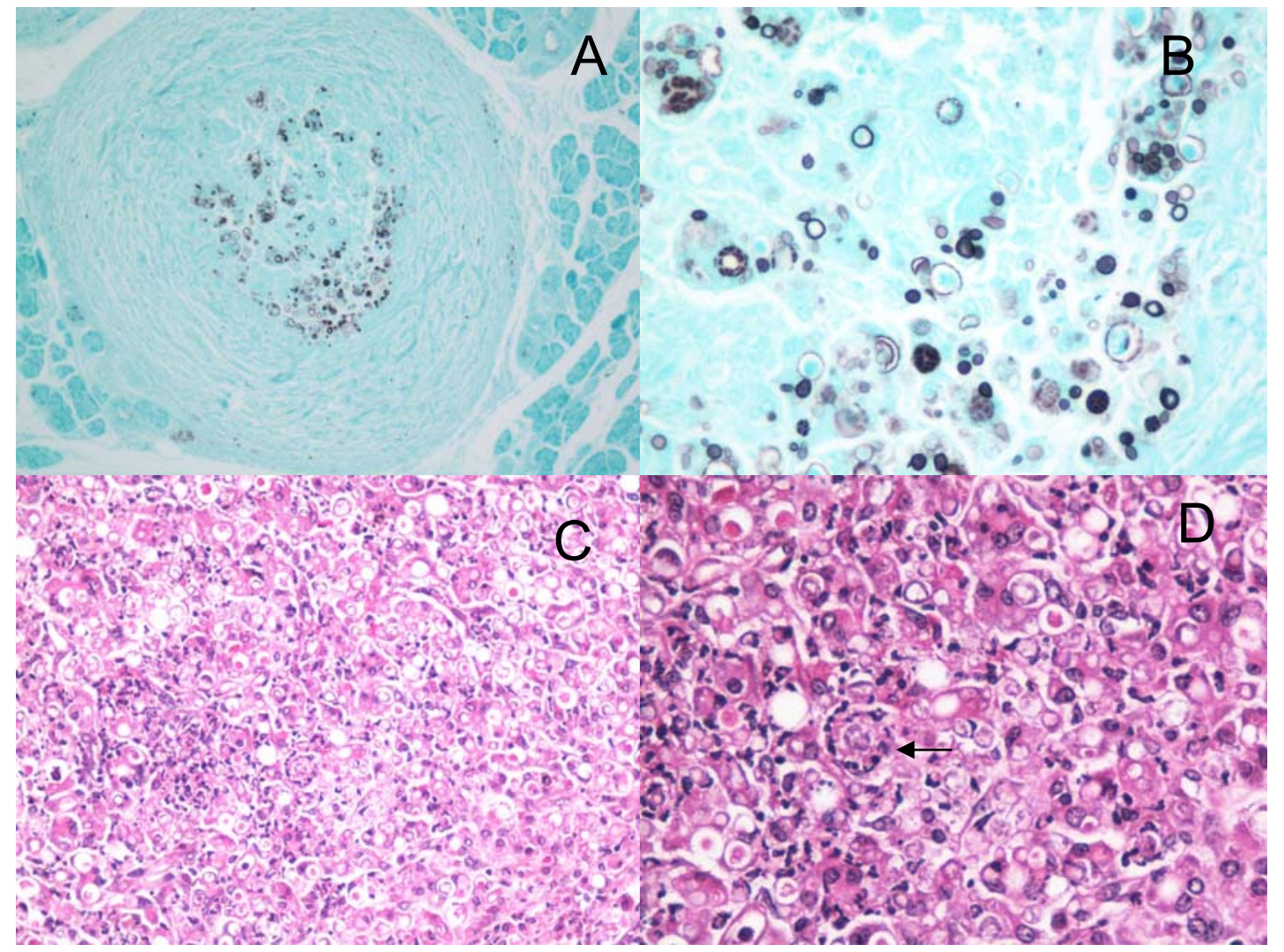

Prancha 18 - Avaliação da disseminação fúngica, aspecto do granuloma e celularidade presente no epíplon através da coloração de Grocott e HE em camundongos infectados e tratados com IFN- $\gamma$, aos 120 dias de infecção - Os animais infectados e tratados com IFN- $\gamma$ apresentaram foco fúngico bem centralizado (A-40x) com a morfologia que variava de típico para atípico (B-400x). Houve a formação de um granuloma compacto $(\mathrm{C}-40 \mathrm{x})$ e a presença de grande número de células inflamatórias (D-400x). 


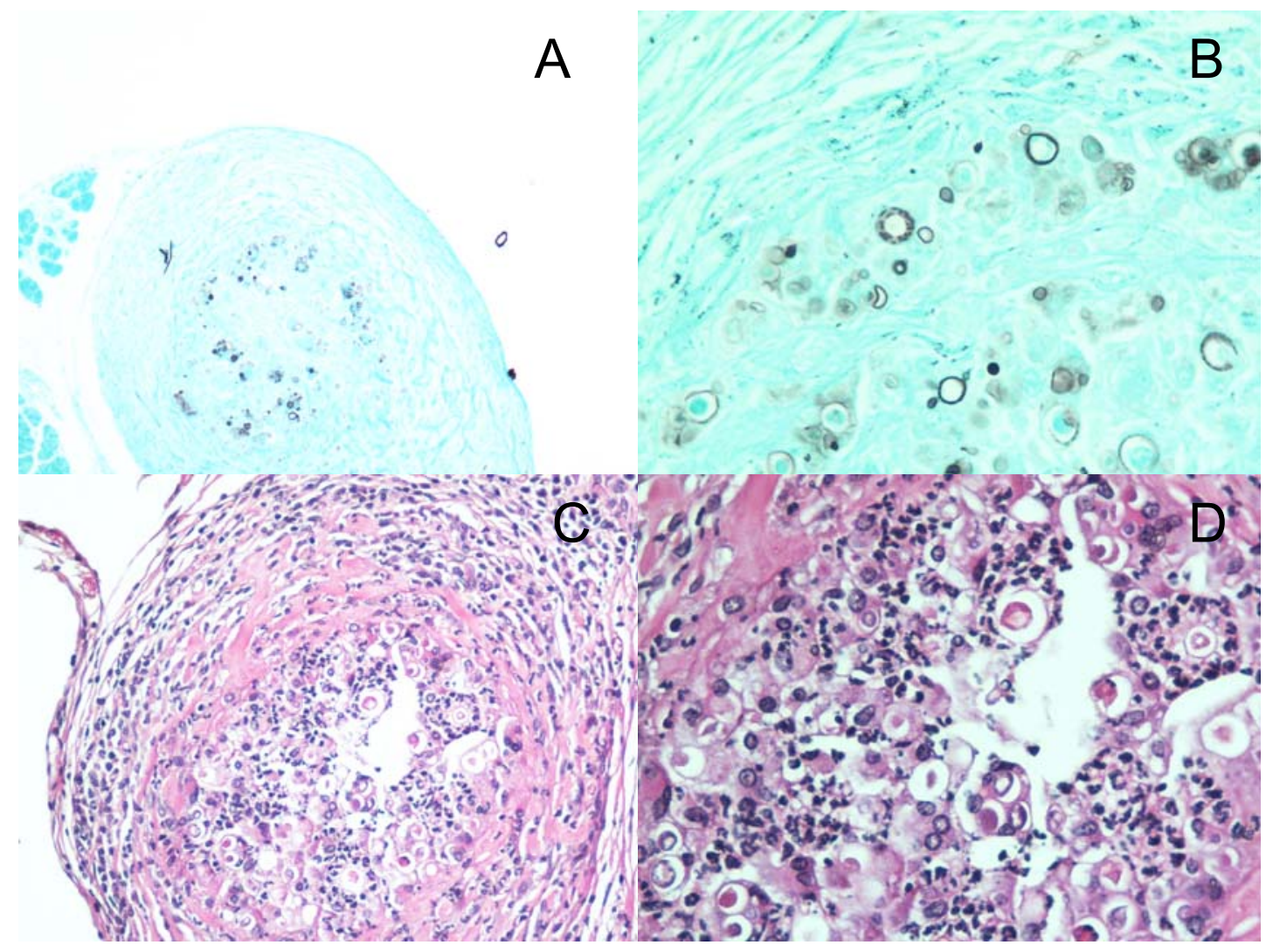

Prancha 19 - Avaliação da disseminação fúngica, aspecto do granuloma e celularidade presente no epíplon através da coloração de Grocott e HE em animais infectados e tratados com Tetraciclina, aos 120 dias de infecção - Os animais infectados e tratados com tetraciclina apresentaram pequeno número de fungos centralizado (A-40x) porém com a maioria apresentando uma morfologia atípica (B-400x). Houve formação de granuloma bem compacto (C-40x) com células inflamatórias sobre a população de fungos (D-400x). 


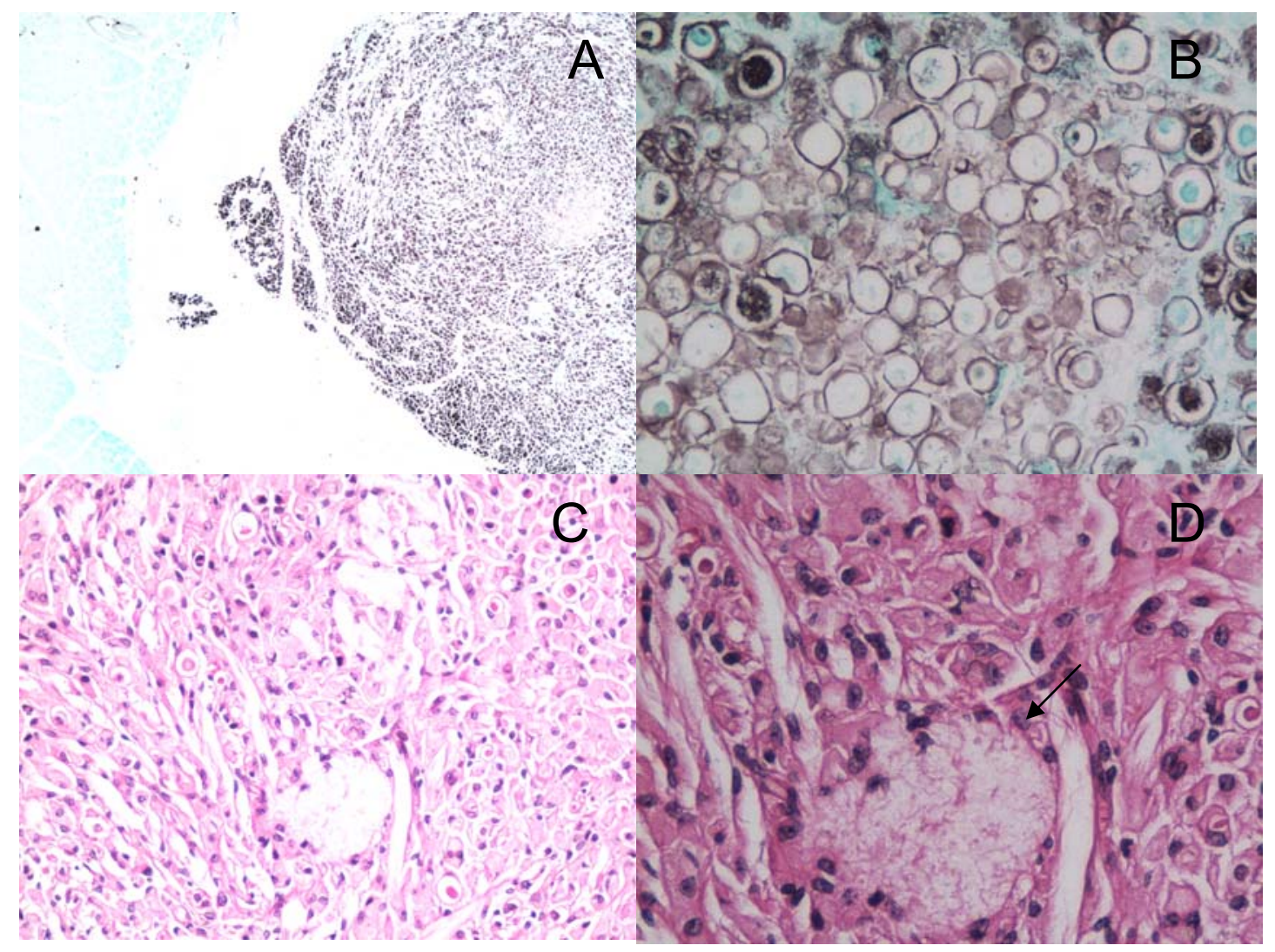

Prancha 20 - Avaliação da disseminação fúngica, aspecto do granuloma e celularidade presente no epíplon através da coloração de Grocott e HE em animais infectados e tratados com Lumiracoxib, aos 120 dias de infecção - Os animais com lumiracoxib apresentaram disseminação fúngica $(A-40 x)$ com sua morfologia típica (B-400x). Houve uma discreta deposição de colágeno sobre o tecido (C-40x) com algumas células gigantes (D-400x). 

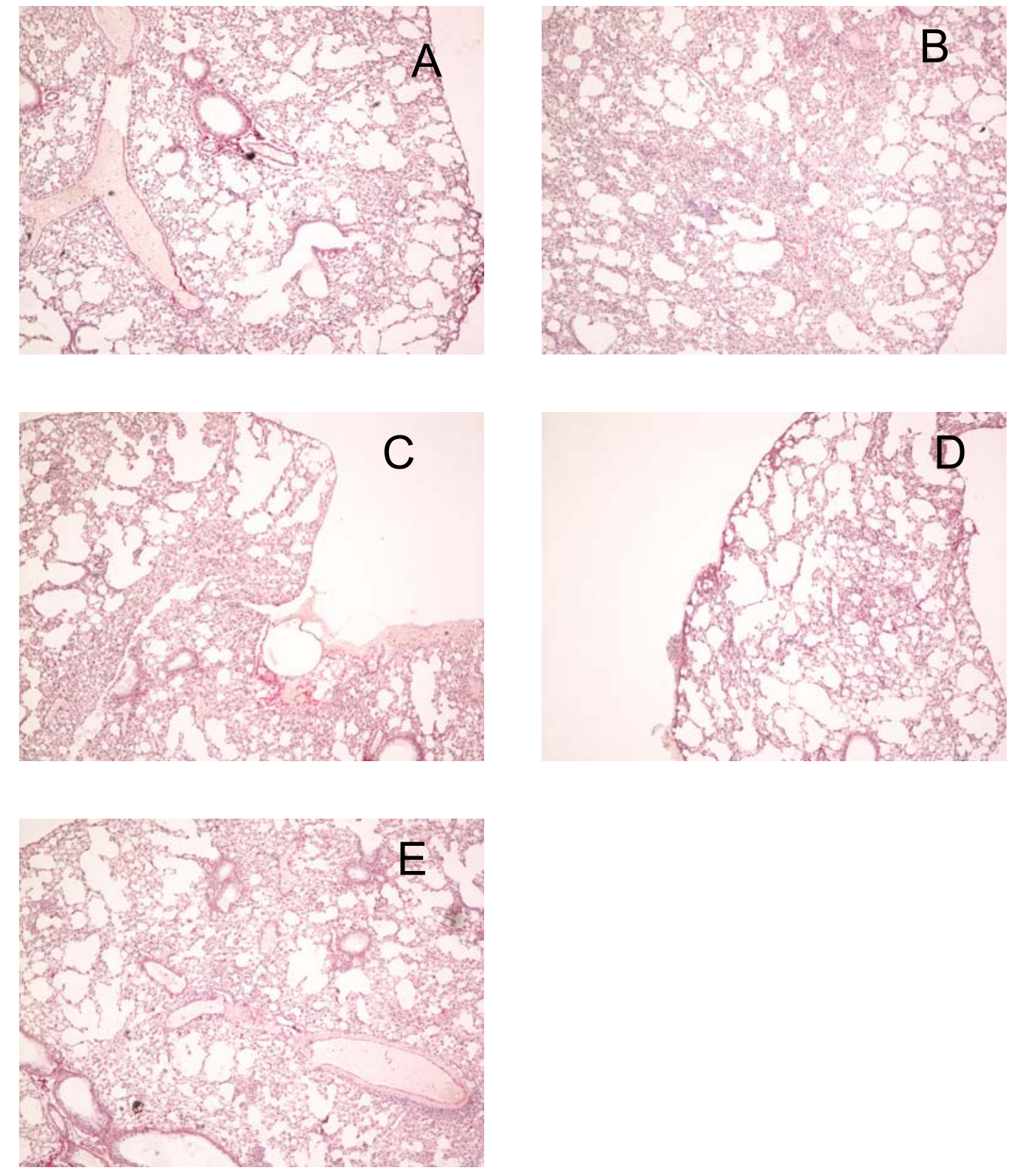

Prancha 21 - Análise histológica de pulmões com a coloração HE aos 15 dias de infecção - Através da analise dos pulmões de todos os grupos estudados, com a coloração de hematoxilina e eosina, pudemos verificar que os animais apenas infectados (A-40x) bem como os que se submeteram a um dos tratamentos, ou com IFN-y (B-40x), com Tetraciclina (C-40x), com Lumiracoxib (D-40x) ou Celecoxib (E-40x) mantiveram a mesma arquitetura e celularidade mostrando que na fase aguda da doença dos animais susceptíveis a PCM, o pulmão não é afetado. 

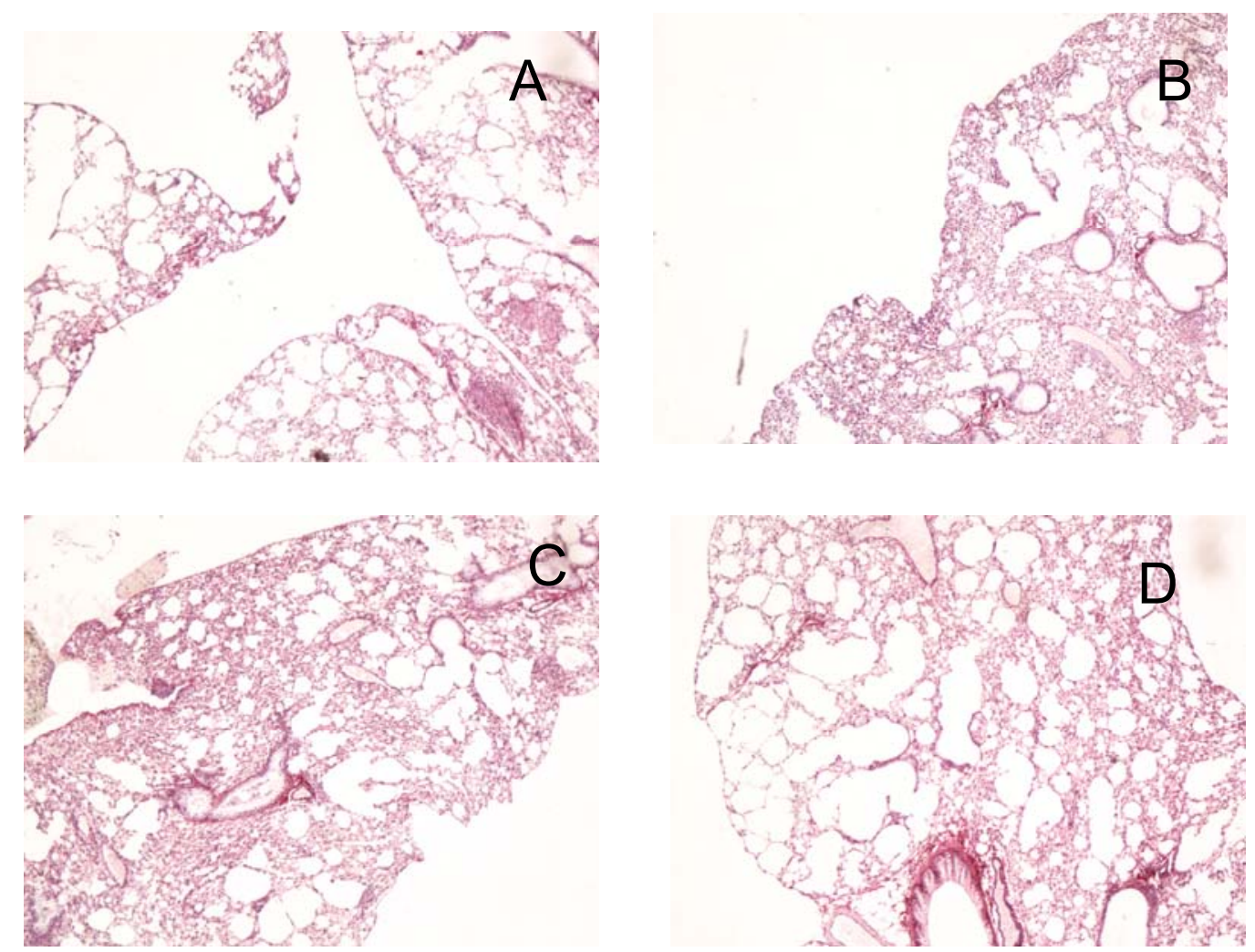

Prancha 22 - Análise histológica de pulmões com a coloração HE aos 120 dias de infecção - Através da analise dos pulmões de todos os grupos estudados, com a coloração de hematoxilina e eosina, pudemos verificar que os animais apenas infectados (A-40x) bem como os que se submeteram a um dos tratamentos, ou com IFN-y (B-40x), com Tetraciclina (C-40x) ou com Lumiracoxib (D-40x) mantiveram a mesma arquitetura e celularidade. 

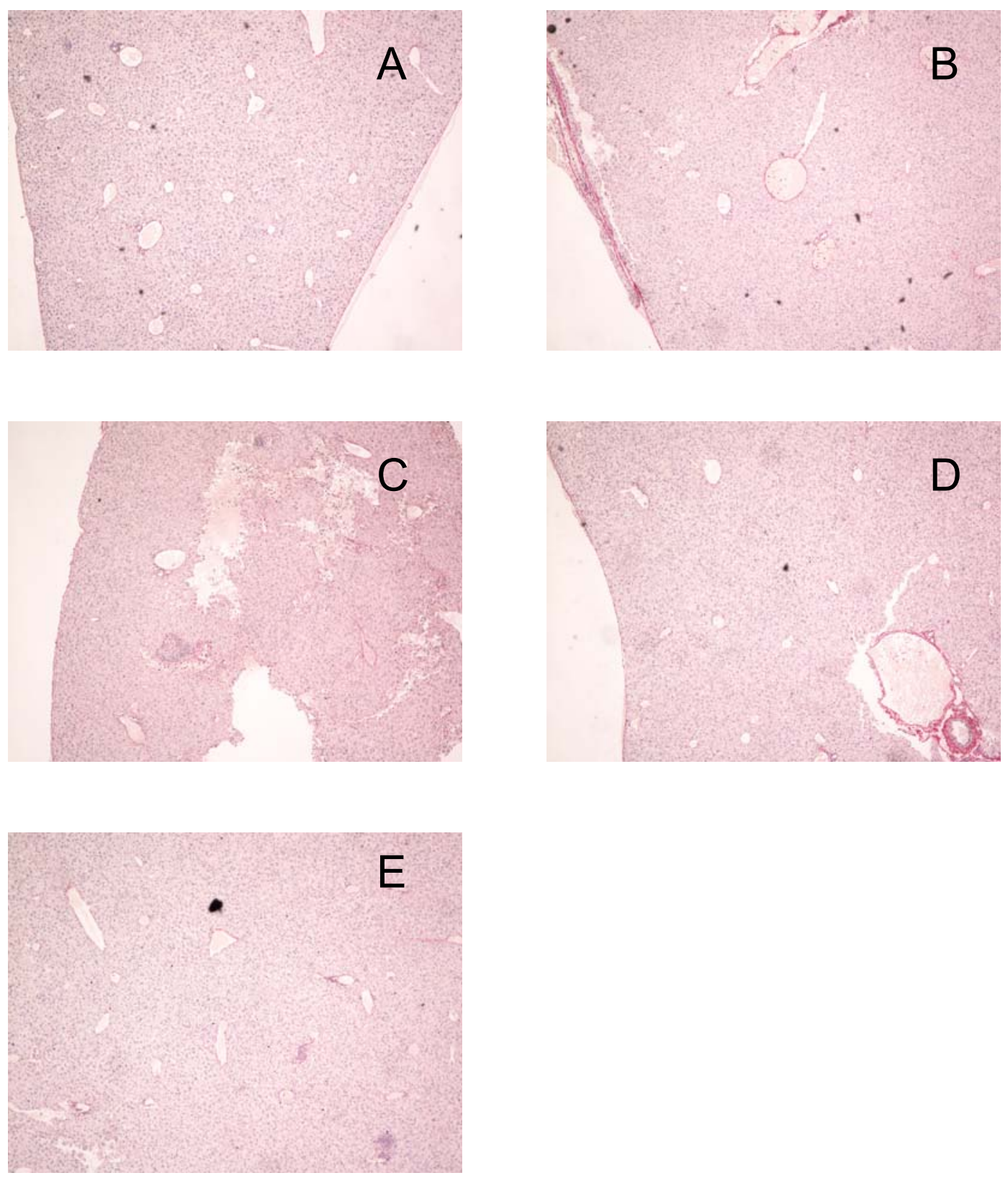

Prancha 23 - Análise histológica de fígado com a coloração HE aos 15 dias de infecção - Através da analise do fígado de todos os grupos estudados, com a coloração de hematoxilina e eosina, pudemos verificar que os animais apenas infectados (A-40x) bem como os que além da infecção se submeteram a um dos tratamentos, ou com IFN-y (B-40x), com Tetraciclina (C-40x), com lumiracoxib (D-40x) ou celecoxib (E-40x) mantiveram a mesma arquitetura e celularidade. 

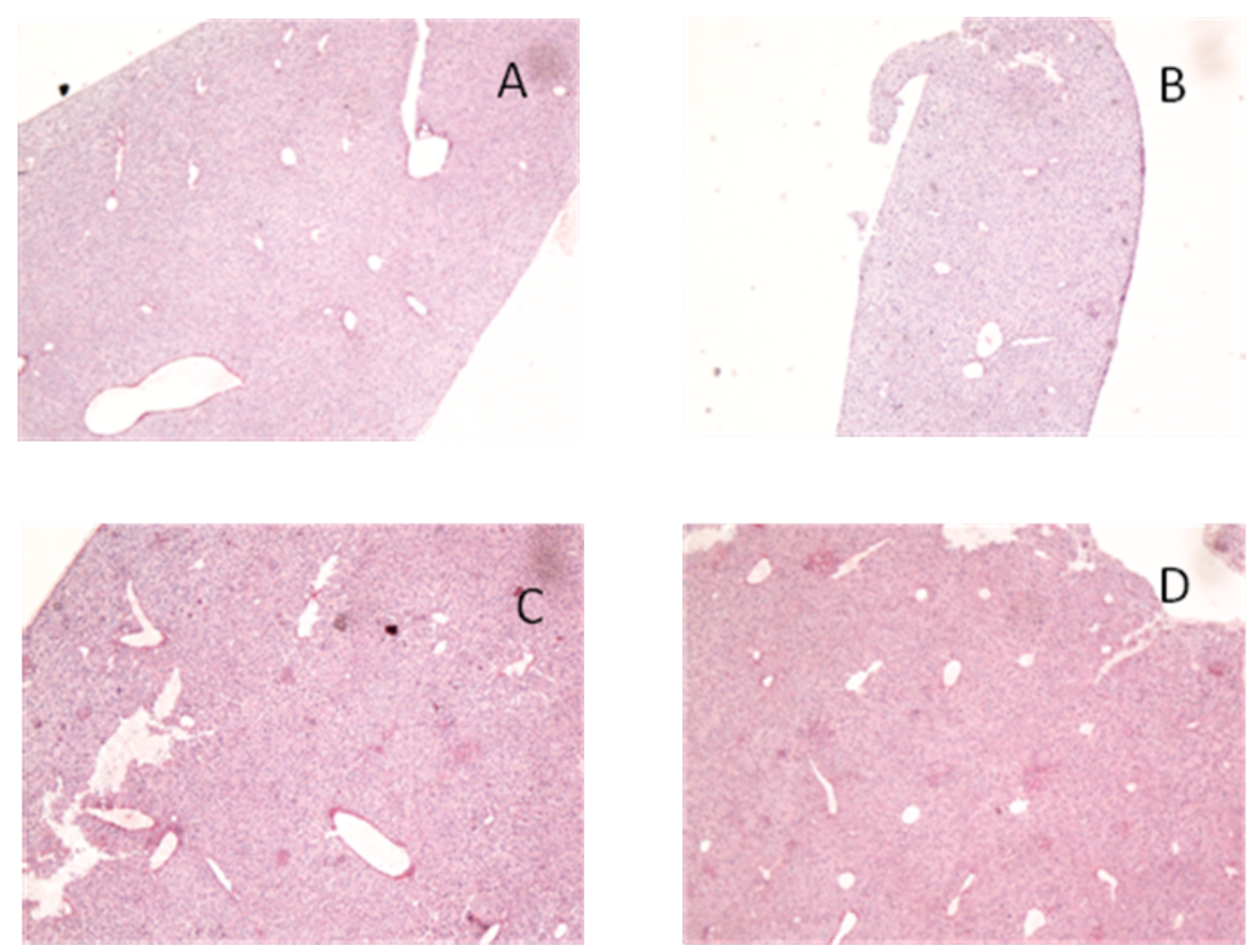

Prancha 24 - Análise histológica de fígado com a coloração HE aos 120 dias de infecção - Através da analise do fígado de todos os grupos estudados, com a coloração de hematoxilina e eosina, pudemos verificar que os animais apenas infectados (A-40x) bem como os que além da infecção se submeteram a um dos tratamentos, ou com IFN-y (B-40x), com Tetraciclina (C-40x), ou com lumiracoxib (D-40x) mantiveram a mesma arquitetura e celularidade. 

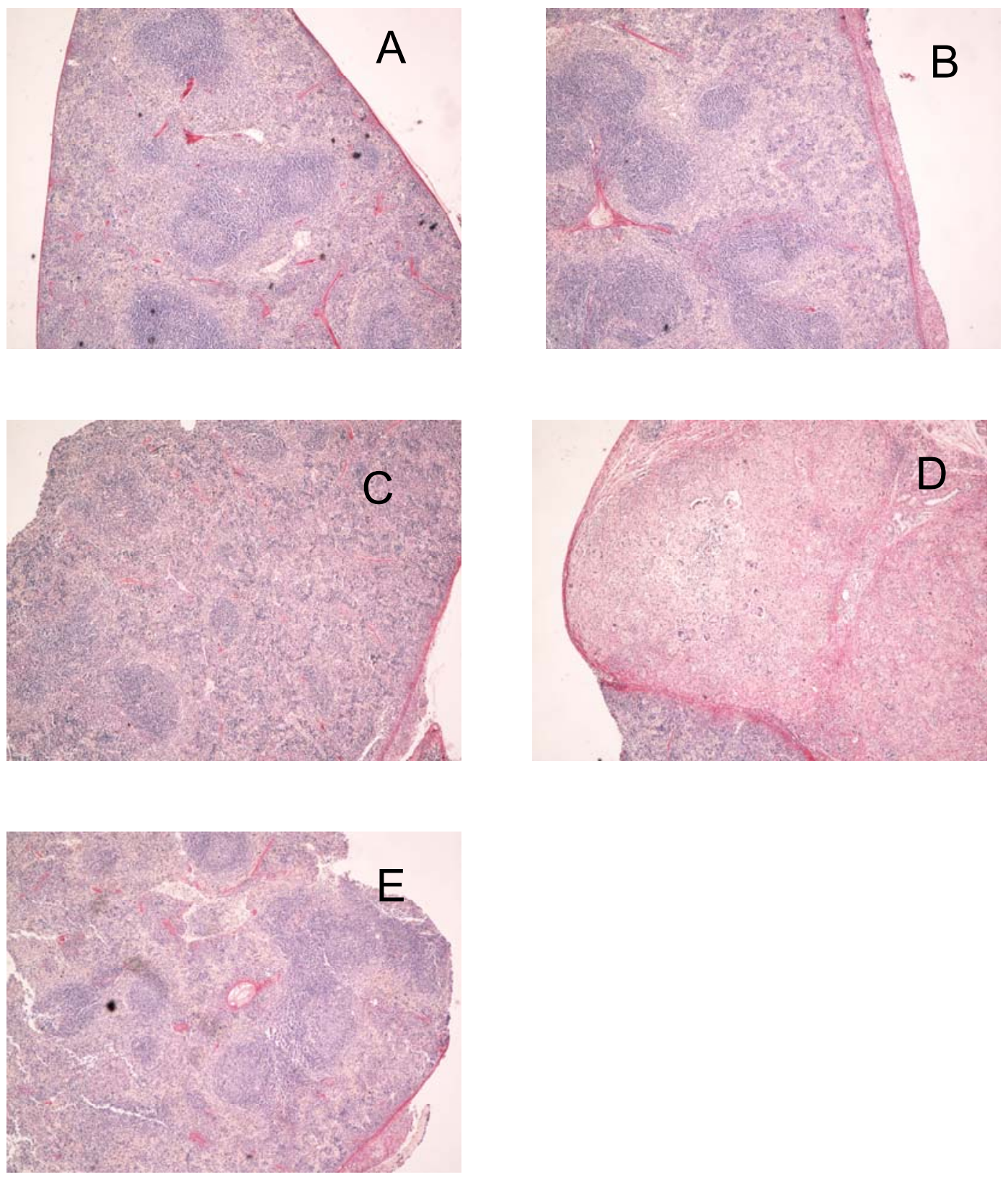

Prancha 25 - Análise histológica de baço a coloração HE aos 15 dias de infecção Através da analise do baço dos grupos estudados, com a coloração de hematoxilina e eosina, pudemos verificar que os animais apenas infectados $(A-40 x)$ ou que além de infectados que se submeteram a um dos tratamentos, ou com IFN-y (B-40x), com Tetraciclina (C-40x), com lumiracoxib (D-40x) ou celecoxib (E-40x) mantiveram a mesma arquitetura e celularidade. 

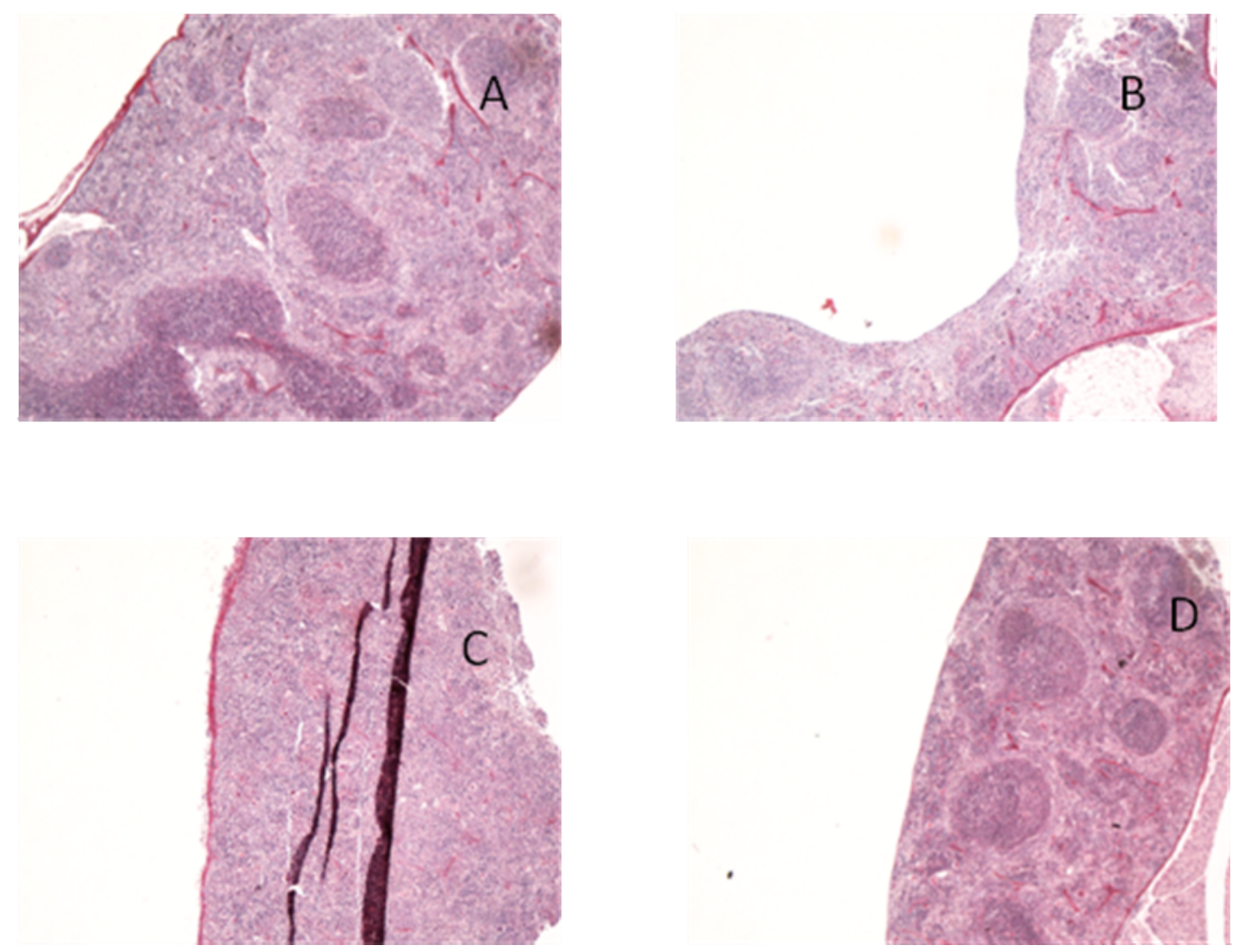

Prancha 26 - Análise histológica de baço a coloração HE aos 120 dias de infecção Através da analise do baço dos grupos estudados, com a coloração de hematoxilina e eosina, pudemos verificar que os animais apenas infectados $(A-40 x)$ ou que além de infectados que se submeteram a um dos tratamentos, ou com IFN-y (B-40x), com Tetraciclina (C-40x) ou lumiracoxib (D-40x) mantiveram a mesma arquitetura e celularidade. 


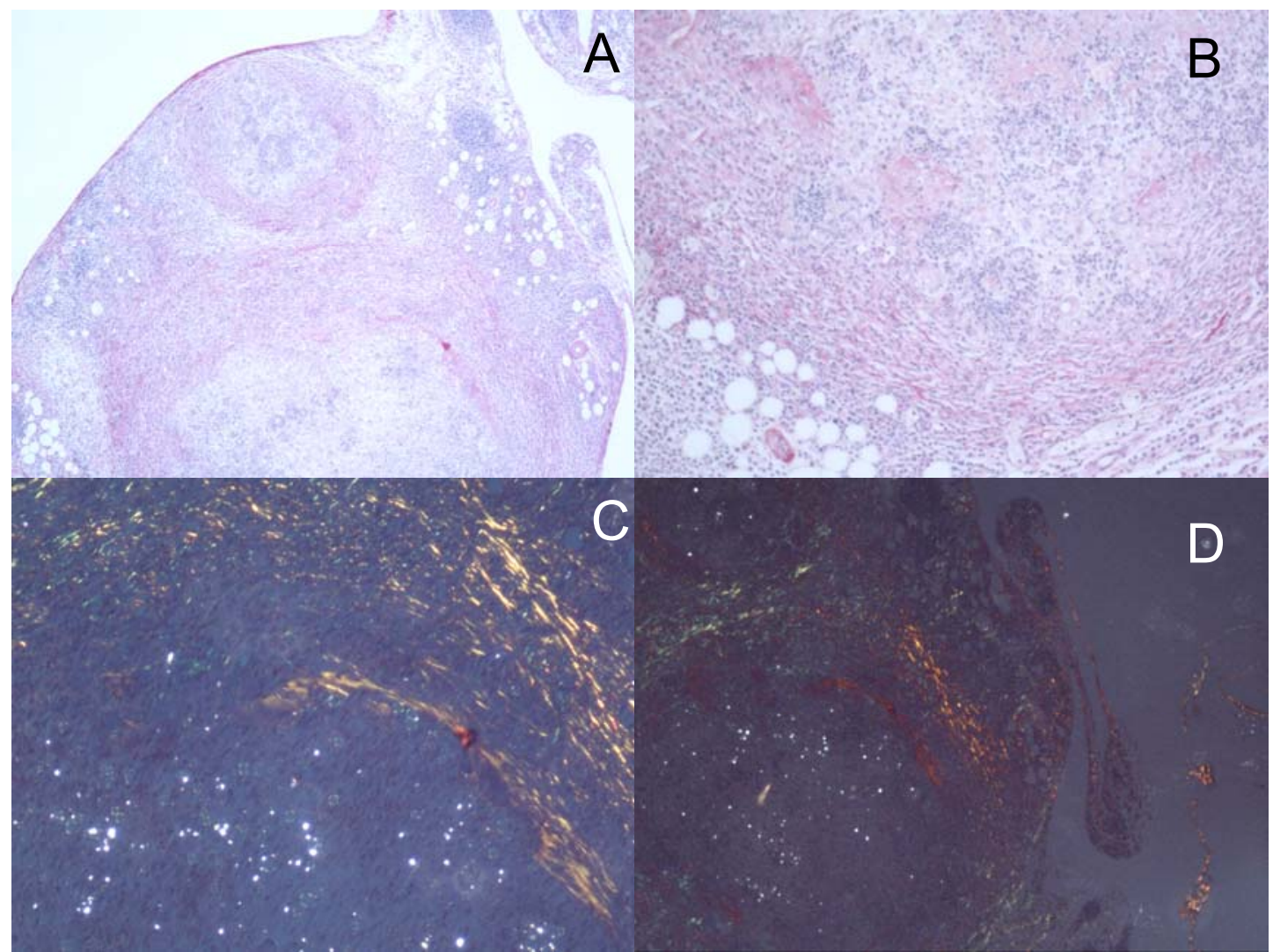

Prancha 27 - Análise das fibras colágenas no epíplon dos animais apenas infectados, aos 15 dias de infecção, corado com Picrosirius - Esses animais apresentaram deposição de fibras colágenas formando um granuloma frouxo (A-40x) com fibras tentando circunscrever o foco fúngico (B-200x). Ao polarizarmos a luz pudemos notar claramente que as fibras não são totalmente uniformes (C-200x) e não fecham completamente a lesão (D-40x). 


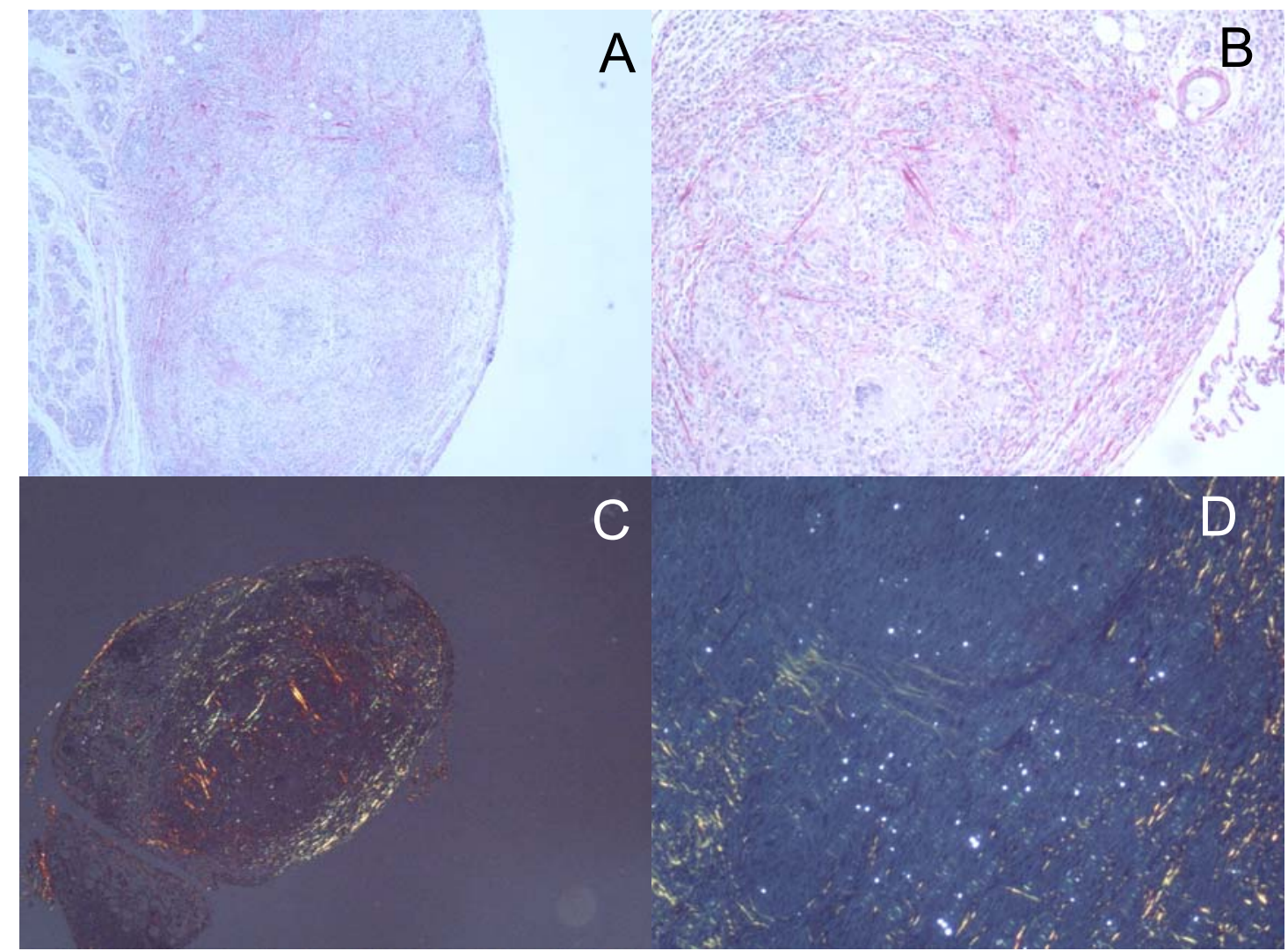

Prancha 28 - Análise das fibras colágenas no epíplon dos animais infectados e tratados com IFN- $\gamma$, aos 15 dias de infecção, corado com Picrosirius Esse grupo de animais apresentaram um granuloma compacto (A-40x) com fibras que circunscreve a lesão (B-200x). Quando polarizado, o corte revela fibras colágenas fechando a lesão (C-40x) em posição uniforme (D200x). 


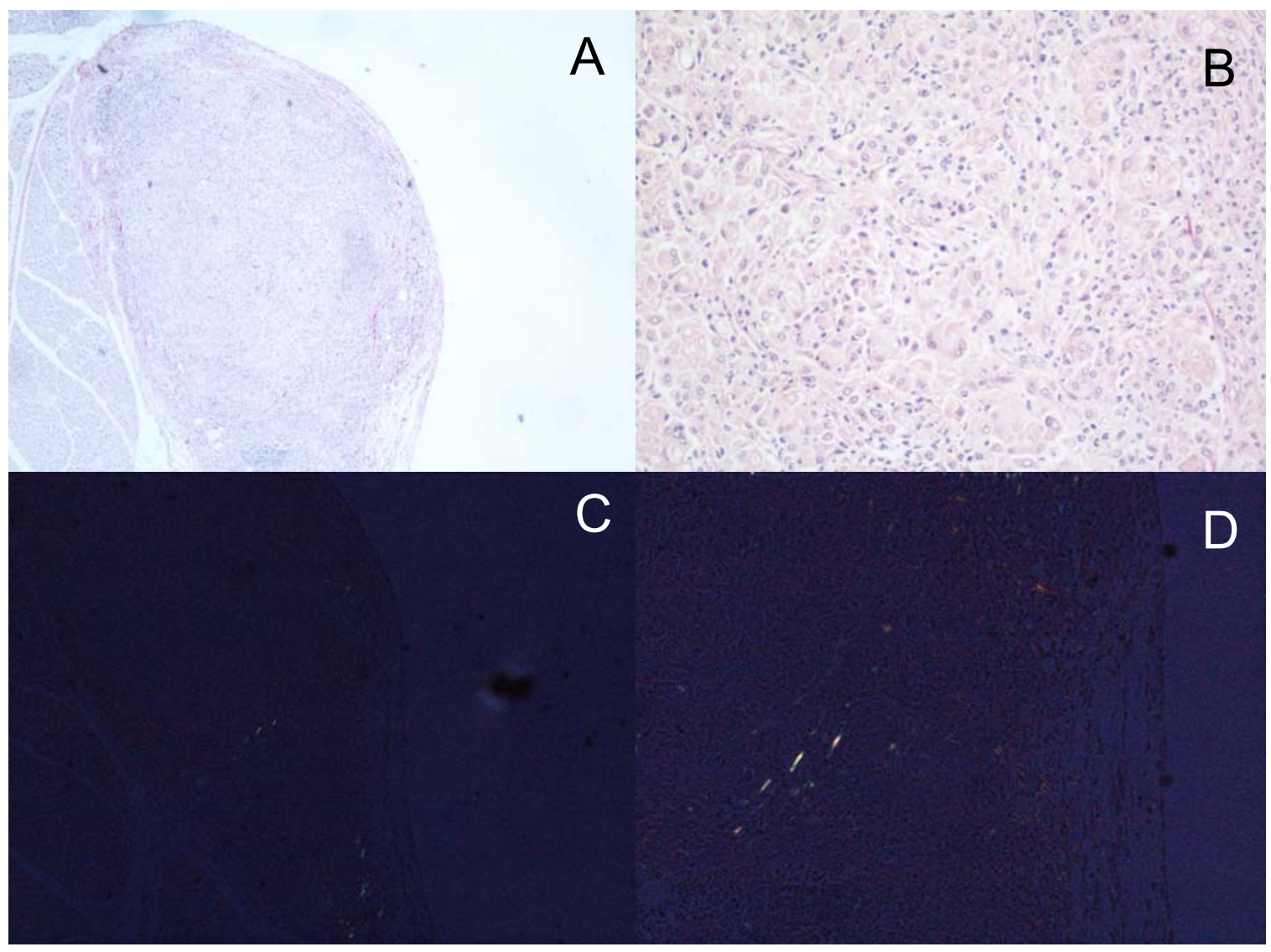

Prancha 29 - Análise das fibras colágenas no epíplon dos animais infectados e tratados com Tetraciclina, aos 15 dias de infecção, corado com Picrosirius - Esse grupo de animais não apresentou granuloma (A-40x) com algumas fibras isoladas (B-200x). Quando polarizado, o corte revela ausência total de colágeno (C-40x) (D-200x). 


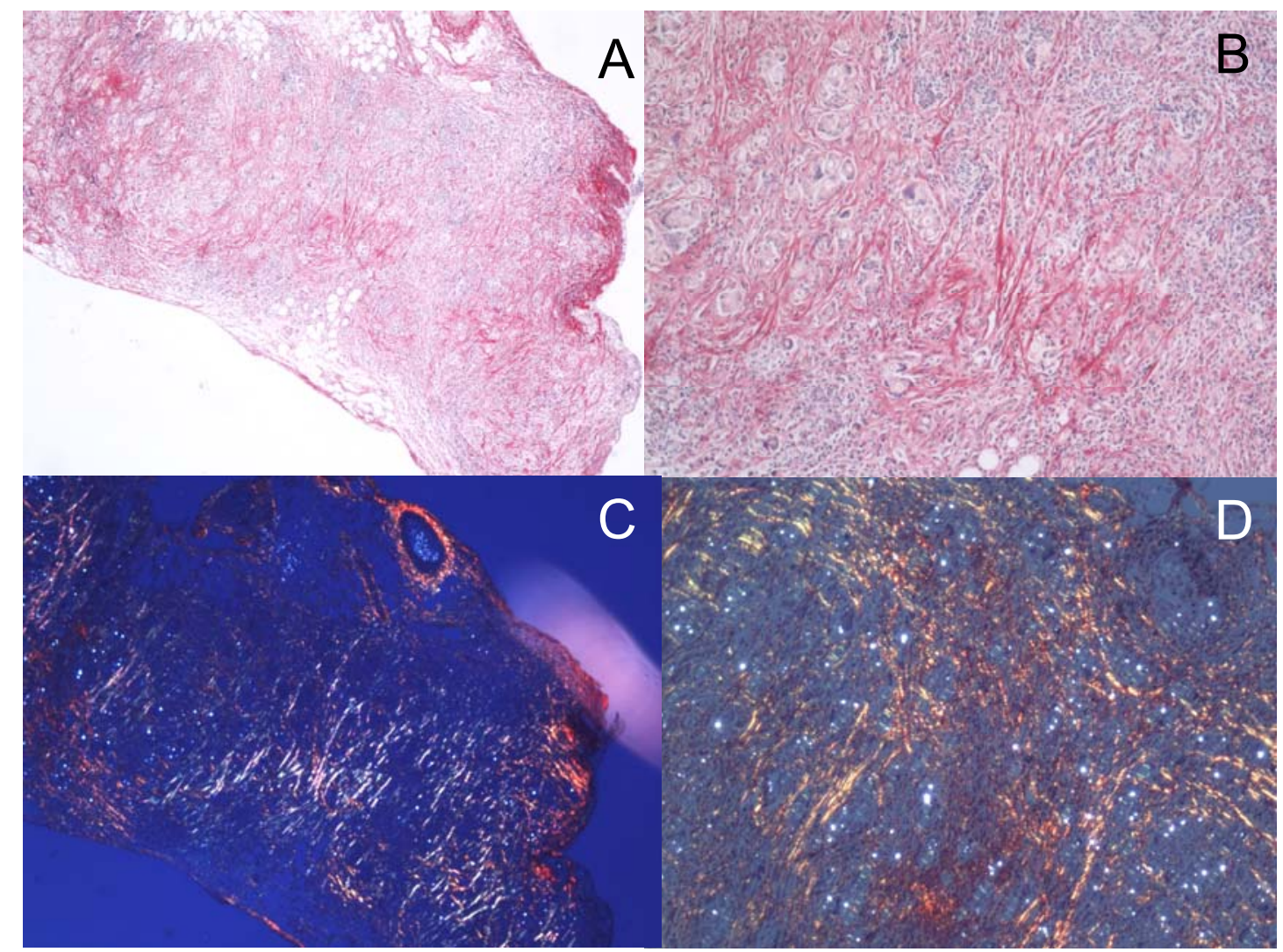

Prancha 30 - Análise das fibras colágenas no epíplon dos animais infectados e tratados com Lumiracoxib, aos 15 dias de infecção, corado com Picrosirius - Esse grupo de animais não apresentou granuloma (A-40x) porém essa ausência se deu pelo deposito muito grande de fibras colágenas(B-200). Quando o corte foi polarizado deu para ver claramente o tecido inteiro com fibras colágenas $(\mathrm{C}-40 \mathrm{x})$ que variavam suas direções entre elas (D-200x). 


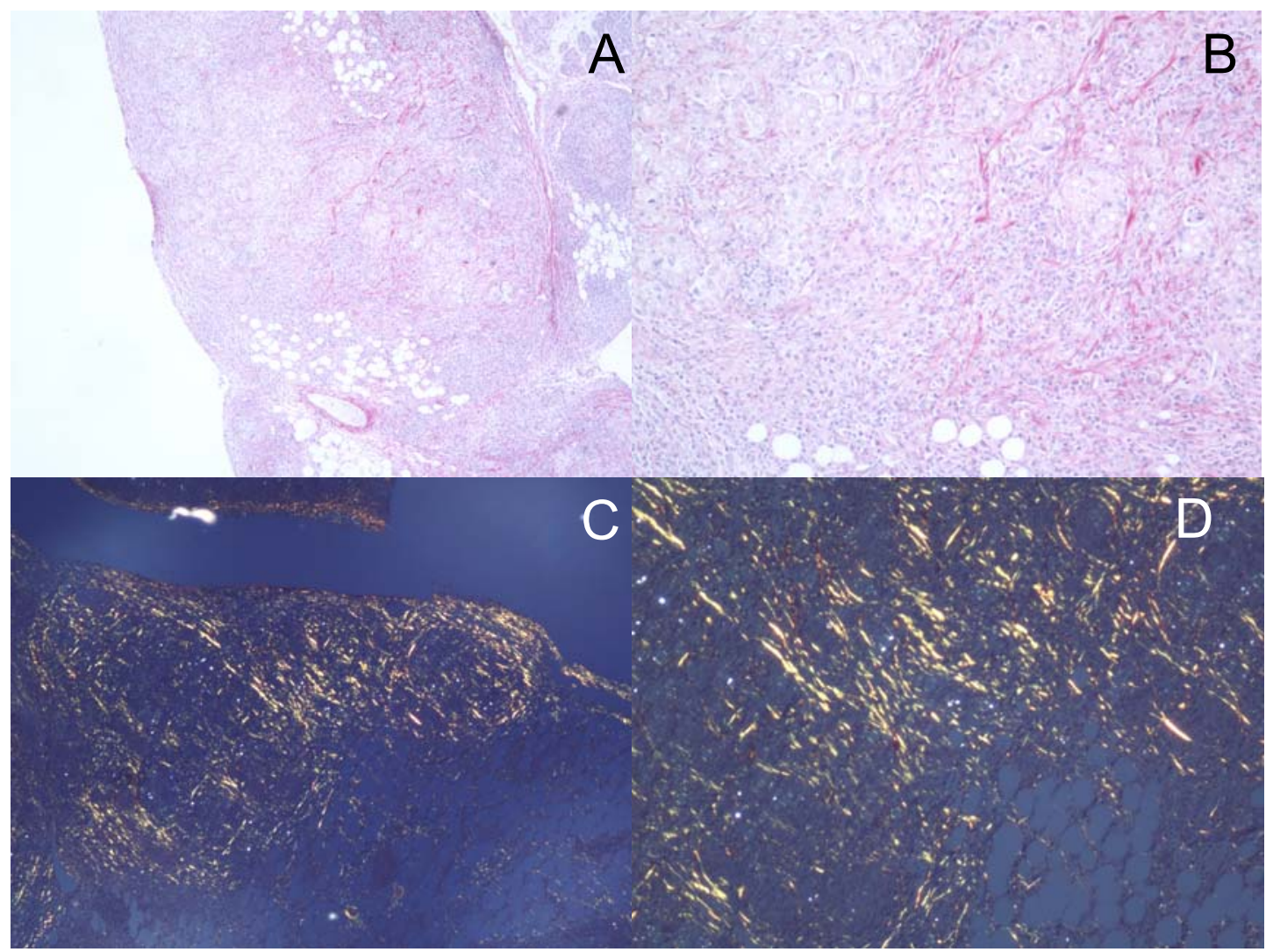

Prancha 31 - Análise das fibras colágenas no epíplon dos animais infectados e tratados com Celecoxib, aos 15 dias de infecção, corado com Picrosirius - Esse grupo de animais não apresentou granuloma (A-40x) porém essa ausência se deu pelo deposito muito grande de fibras colágenas(B-200). Quando o corte foi polarizado deu para ver claramente o tecido inteiro com fibras colágenas $(\mathrm{C}-40 \mathrm{x})$ que variavam suas direções entre elas (D-200x). 


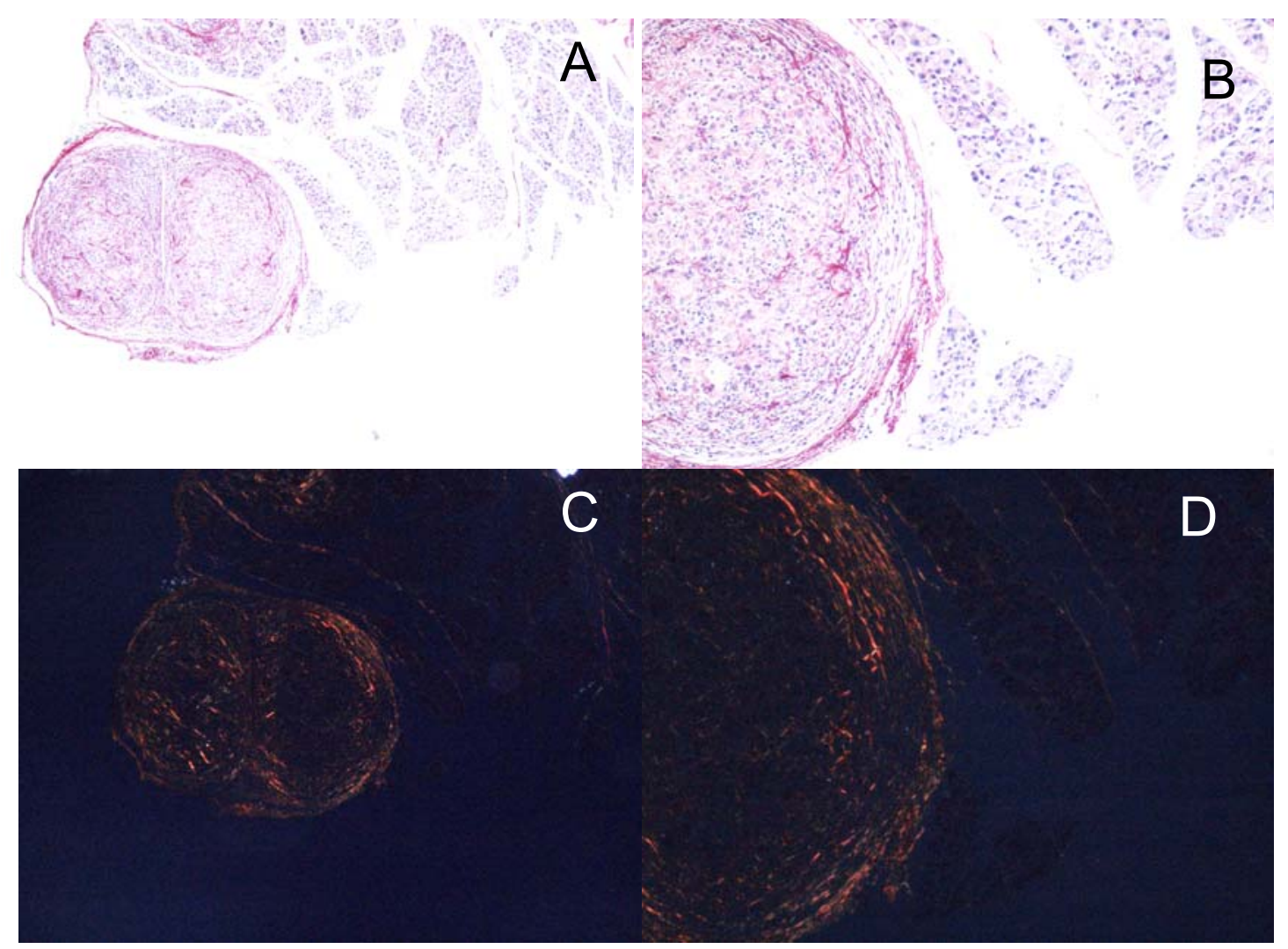

Prancha 32 - Análise das fibras colágenas no epíplon dos animais apenas infectados, aos 120 dias de infecção, corado com Picrosirius - Esses animais apresentaram deposição de fibras colágenas formando um granuloma frouxo (A-40x) com fibras tentando circunscrever o foco fúngico (B-200x). Ao polarizarmos a luz pudemos notar claramente que as fibras não são totalmente uniformes (C-200x) e não fecham completamente a lesão (D-40x). 


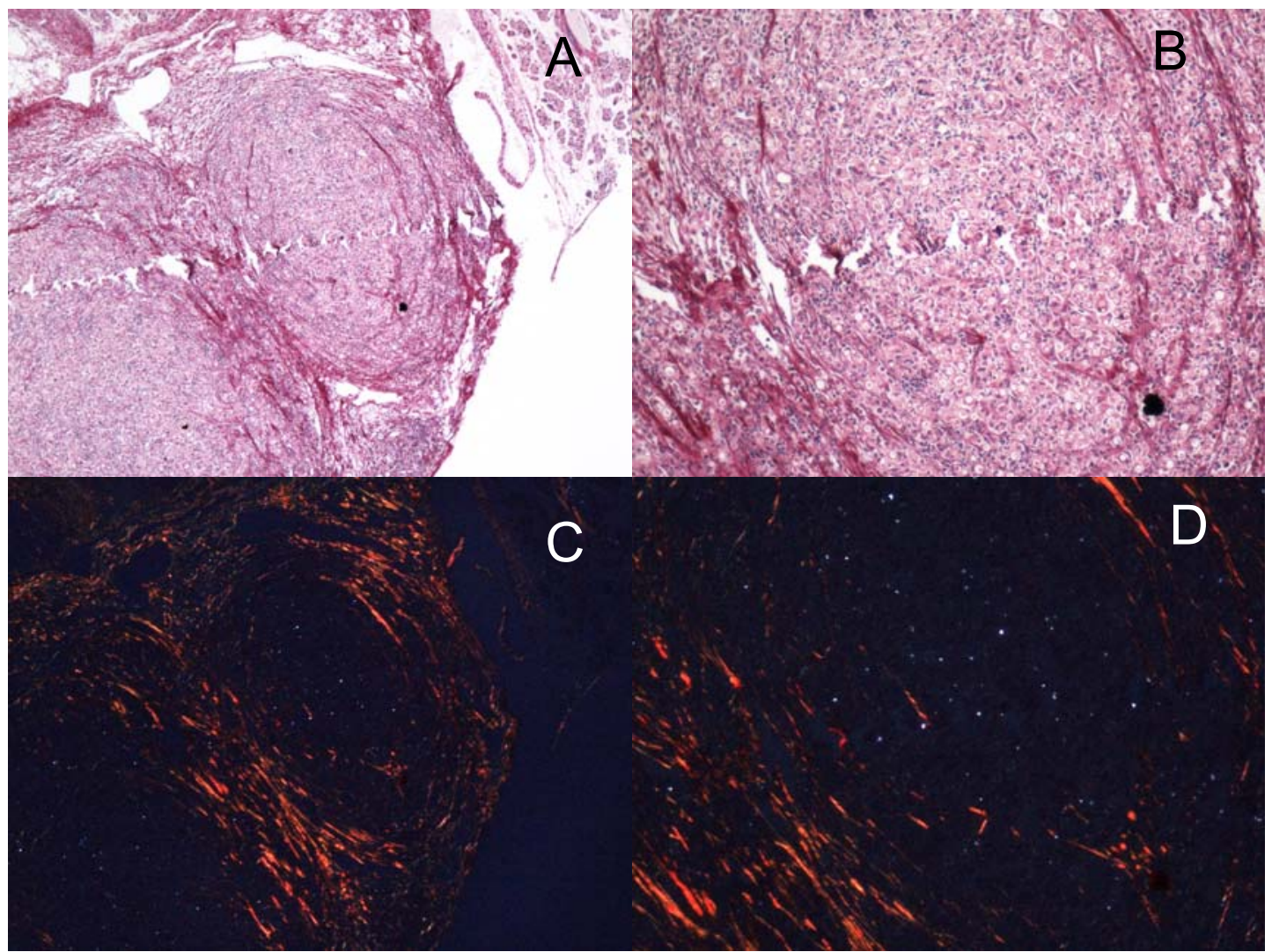

Prancha 33 - Análise das fibras colágenas no epíplon dos animais infectados e tratados com IFN- $\gamma$, aos 120 dias de infecção, corado com Picrosirius Esse grupo de animais apresentaram um granuloma compacto (A-40x) com fibras que circunscreve a lesão (B-200x). Quando polarizado, o corte revela fibras colágenas fechando a lesão (C-40x) em posição uniforme (D-200x). 


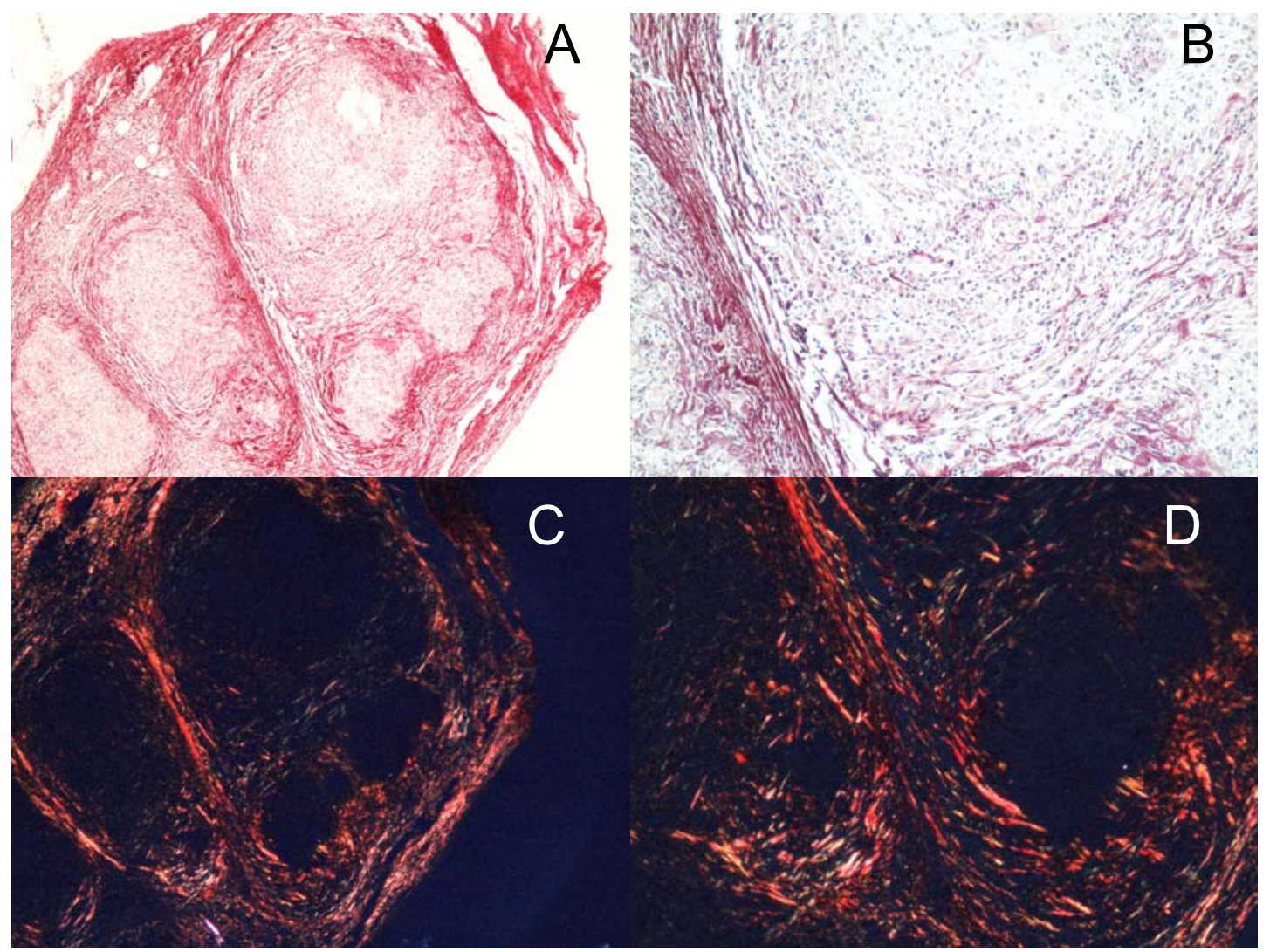

Prancha 34 - Análise das fibras colágenas no epíplon dos animais infectados e tratados com Tetraciclina, aos 120 dias de infecção, corado com Picrosirius - Esse grupo de animais apresentou granuloma espesso, bem compacto (A-40x) com fibras bem marcantes (B-200x). Quando polarizado, o corte revela fibras colágenas bem organizadas $(C-40 x)$ finas e grossas ( $D$ 200x). 


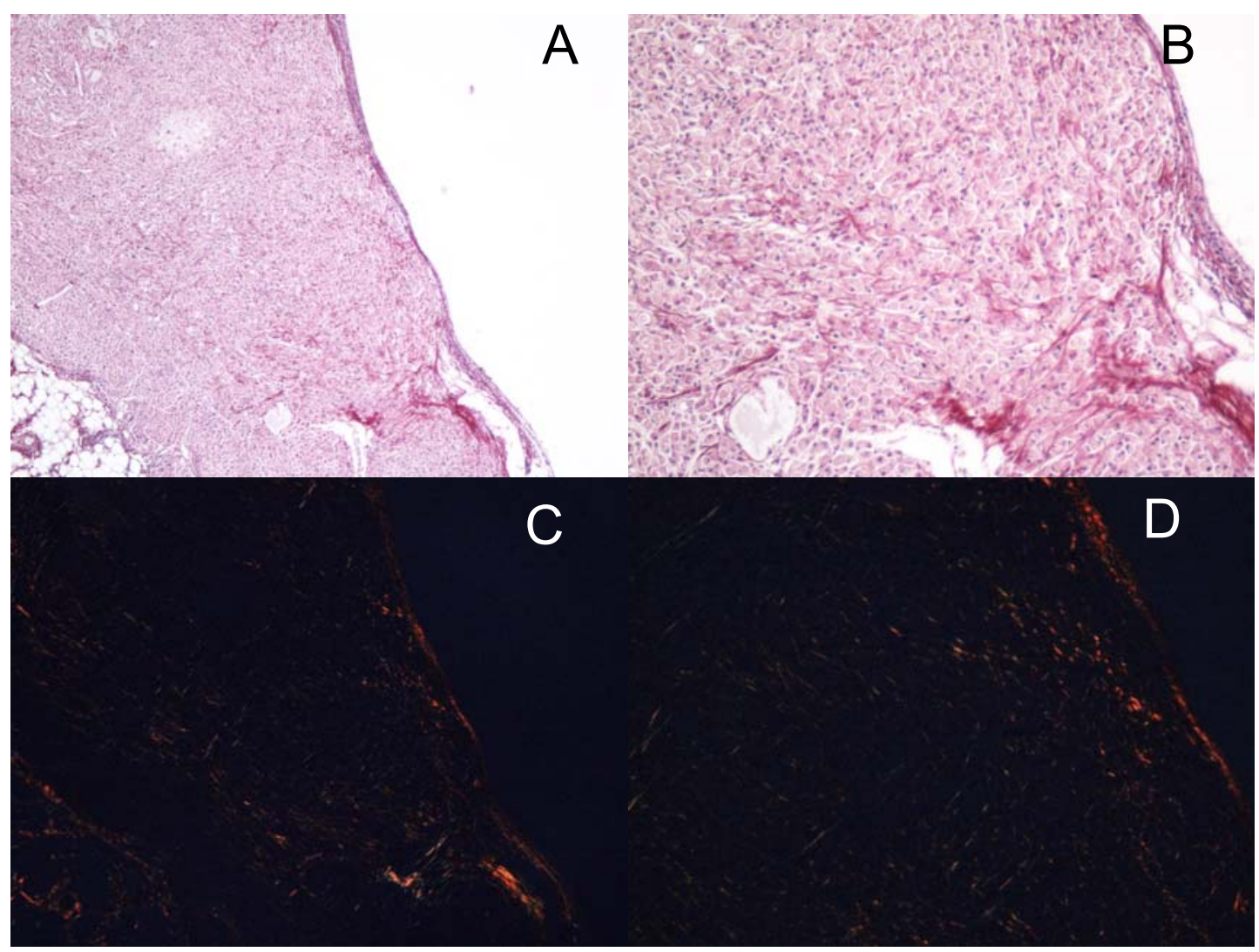

Prancha 35 - Análise das fibras colágenas no epíplon dos animais infectados e tratados com Lumiracoxib, aos 120 dias de infecção, corado com Picrosirius - Esse grupo de animais não apresentou granuloma (A-40x) essa ausência se deu pelo deposito de poucas fibras colágenas (B-200). Quando o corte foi polarizado notamos pouca fibra polarizada (C-40x) que variavam suas direções entre elas (D-200x). 


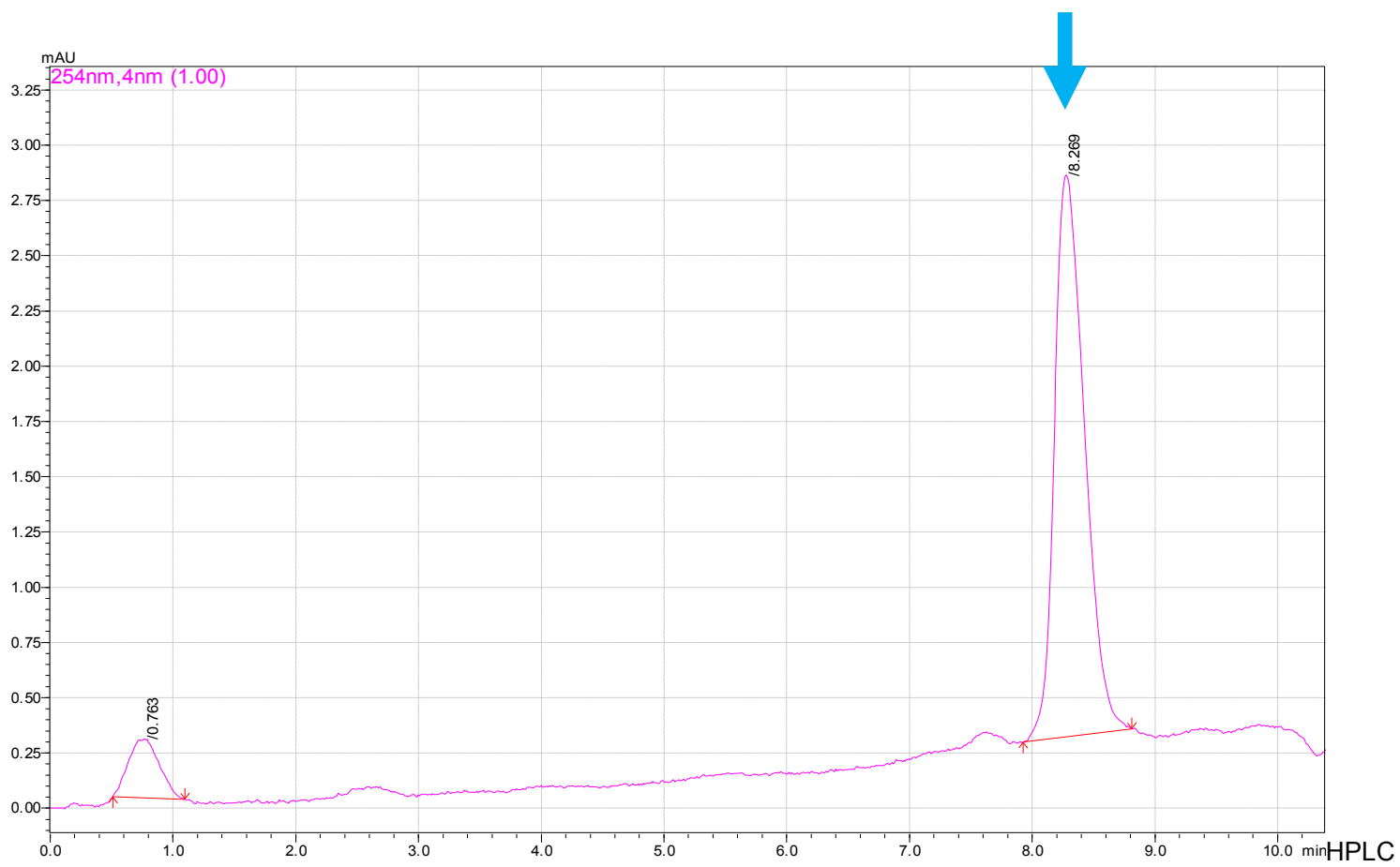

HPLC - padrão de hidroxiprolina 10mM (a)

\begin{tabular}{|l|l|}
\hline \multicolumn{1}{|c|}{ Tempo de retenção (minutos) } & \multicolumn{1}{c|}{ Área do pico (254nm) } \\
\hline 7.686 & 33207 \\
\hline
\end{tabular}

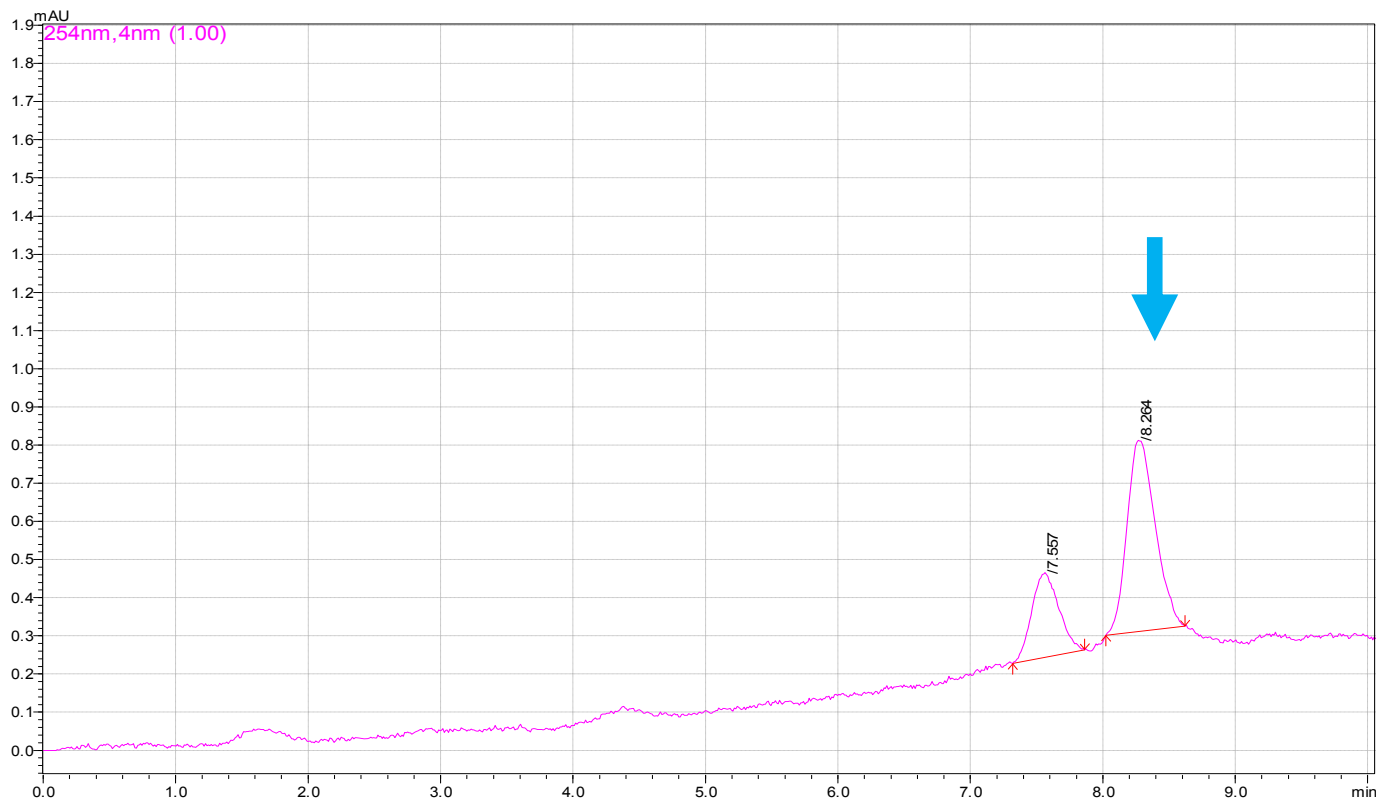

HPLC - padrão de hidroxiprolina $1 \mathrm{mM}$ (a)

\begin{tabular}{|l|l|}
\hline \multicolumn{1}{|c|}{ Tempo de retenção (minutos) } & \multicolumn{1}{c|}{ Área do pico (254nm) } \\
\hline 8.264 & 7454 \\
\hline
\end{tabular}

Figura 15 - Determinação do tempo de retenção de hidroxiprolina presente no epíplon de camundongos B10.A. 


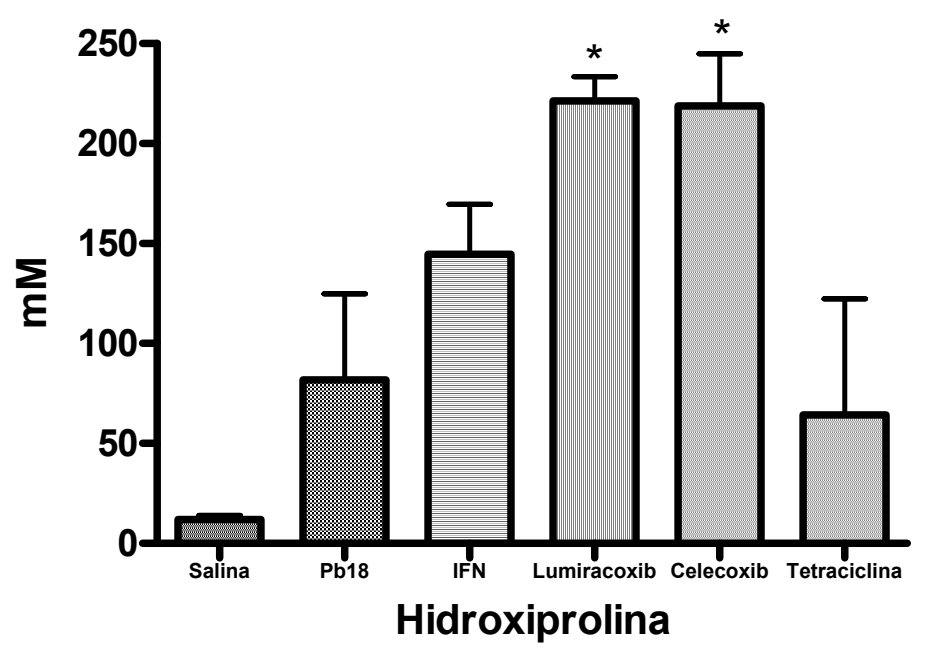

Figura 16 - Concentração de hidroxiprolina presente no epíplon de camundongos B10.A submetido a um dos tratamentos (IFN- $\gamma$; Tetraciclina; Lumiracoxib; Celecoxib) ou apenas infectados, aos 15 dias de infecção. As barras representam o erro médio padrão.

* - Diferença estatística significativa com $p<0,05$ em relação aos controles apenas infectados. 


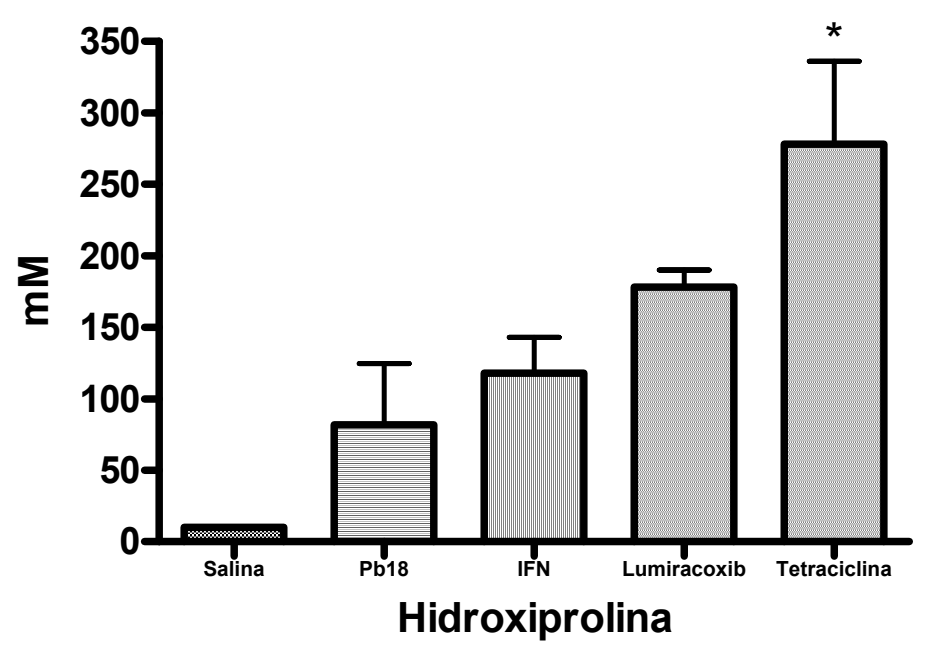

Figura 17 - Concentração de hidroxiprolina presente no epíplon de camundongos B10.A submetido a um dos tratamentos (IFN- $\gamma$; Tetraciclina; Lumiracoxib) ou apenas infectados, aos 120 dias de infecção. As barras representam o erro médio padrão.

* - Diferença estatística significativa com $p<0,05$ em relação aos controles apenas infectados. 

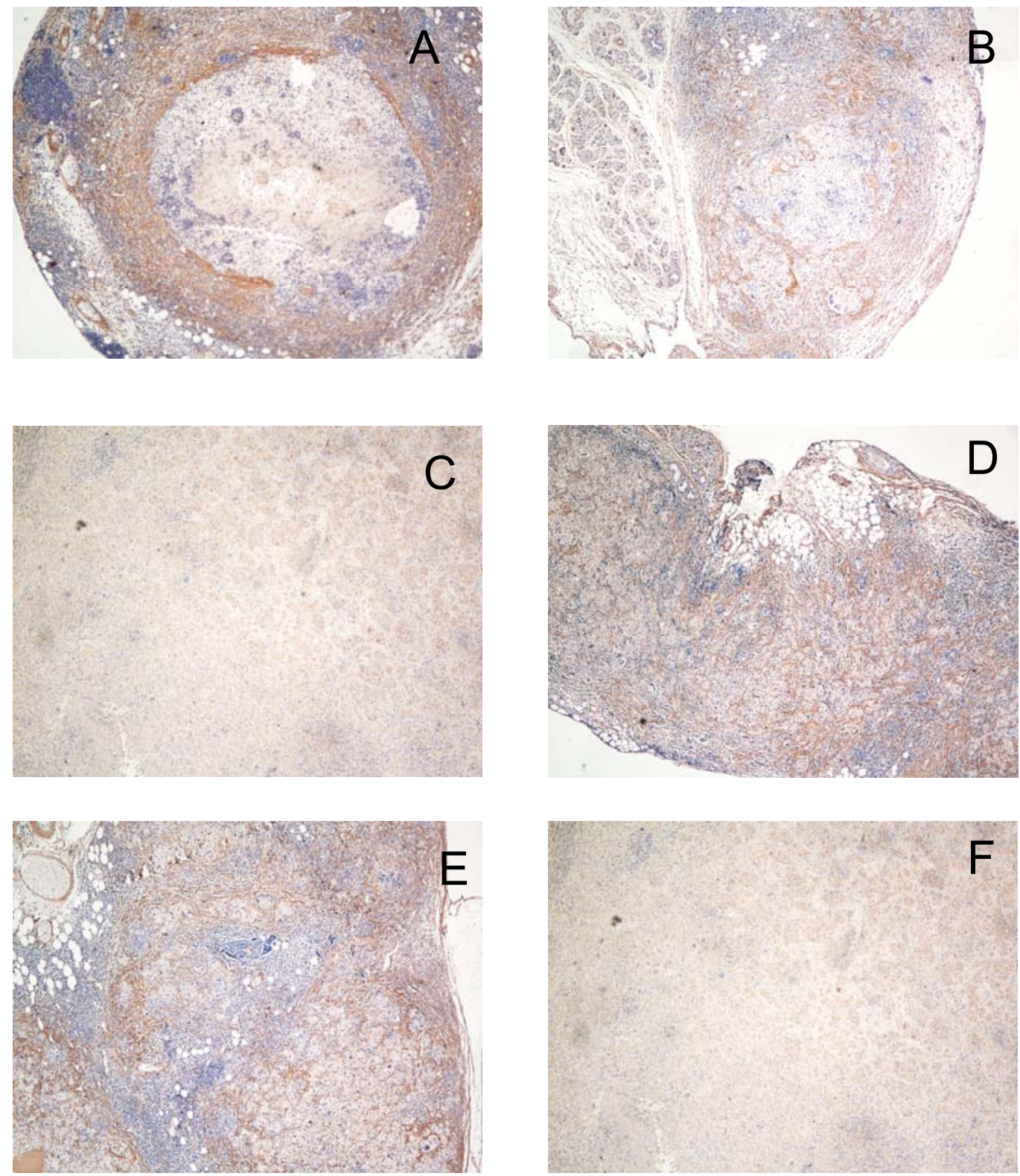

Prancha 36 - Reação de estreptavidina-peroxidade para detecção de colágeno I aos 15 dias de infecção - A - O grupo de animais apenas infectados apresentou marcação positiva com formação de granuloma frouxo (40x). B - Os animais tratados com IFN- $\gamma$ apresentaram marcação positiva, com formação de granuloma compacto (40x). C - O grupo de animais tratados com Tetraciclina apresentou marcação negativa não havendo formação de granuloma (40x). D - Os animais tratados com Lumiracoxib, apresentaram intensa marcação positiva, com fibras tomando todo o tecido (40x). E - Os animais tratados com Celecoxib apresentaram marcação positiva bem marcante, por todo o tecido (40x). F - Corte para controle negativo, sem a adição de anticorpo primário. 

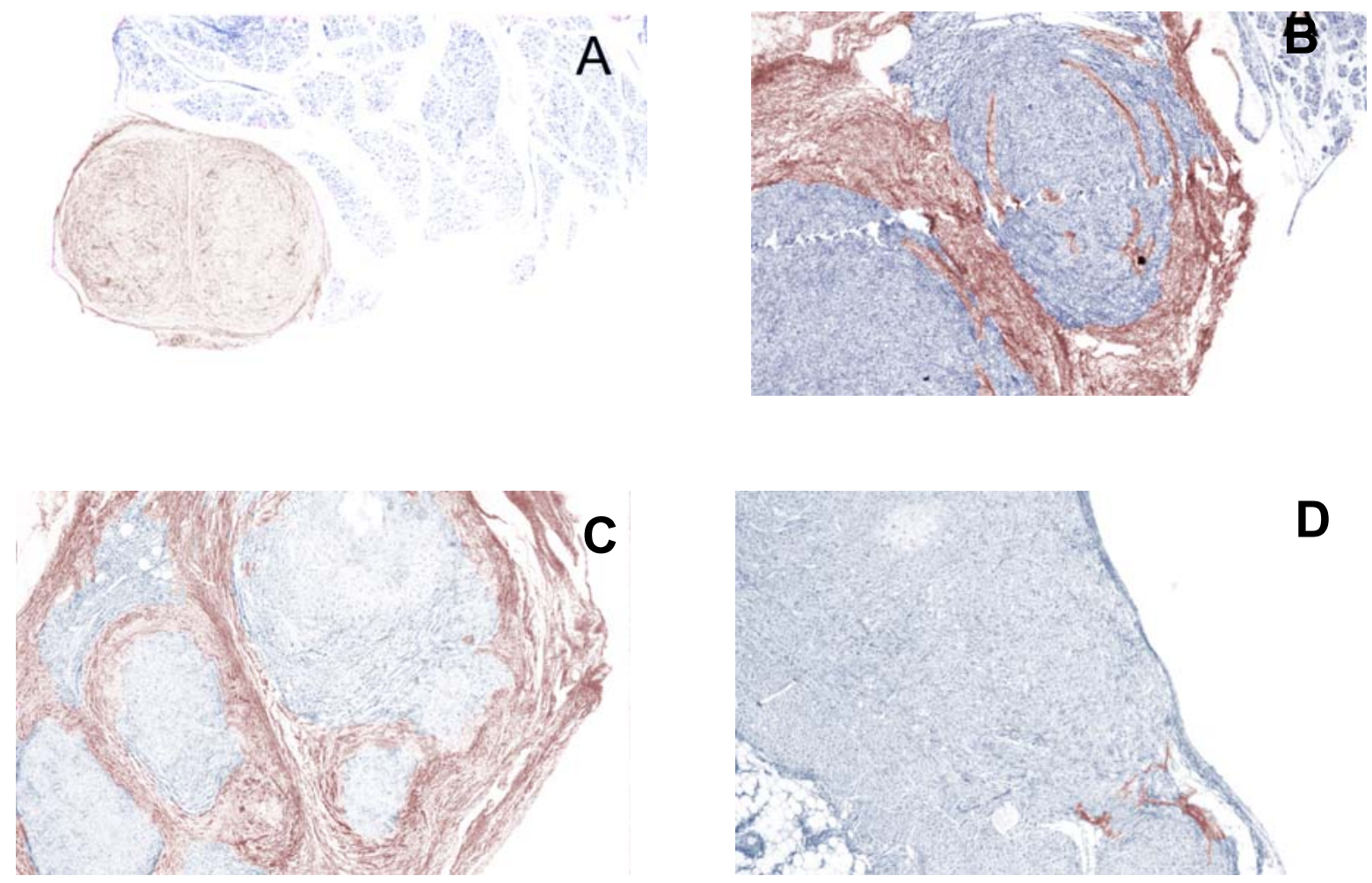

Prancha 37 - Reação de estreptavidina-peroxidade para detecção de colágeno I aos 120 dias de infecção - A - O grupo de animais apenas infectados apresentou marcação positiva com formação de granuloma frouxo (40x). B Os animais tratados com IFN- $\gamma$ apresentaram marcação positiva, com formação de granuloma compacto (40x). C - O grupo de animais tratados com Tetraciclina apresentou marcação negativa não havendo formação de granuloma (40x). D - Os animais tratados com Lumiracoxib, apresentaram intensa marcação positiva, com fibras tomando todo o tecido (40x). 


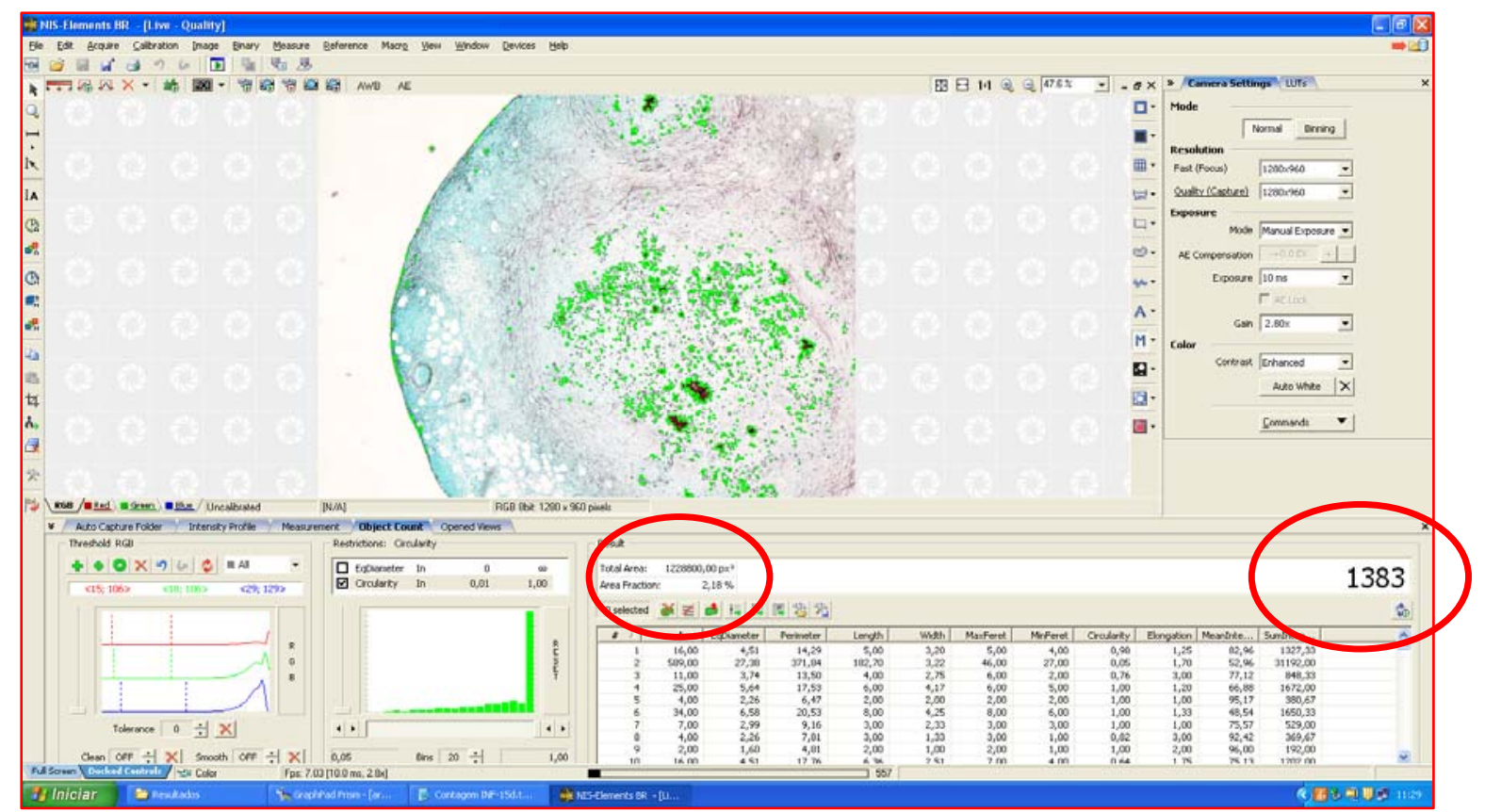

Figura 18 - A figura representa uma imagem capturada pelo microscópio Nikon ECLIPSE 80i e feita à contagem quantitativa da imagem capturada pelo programa NIS Br. 

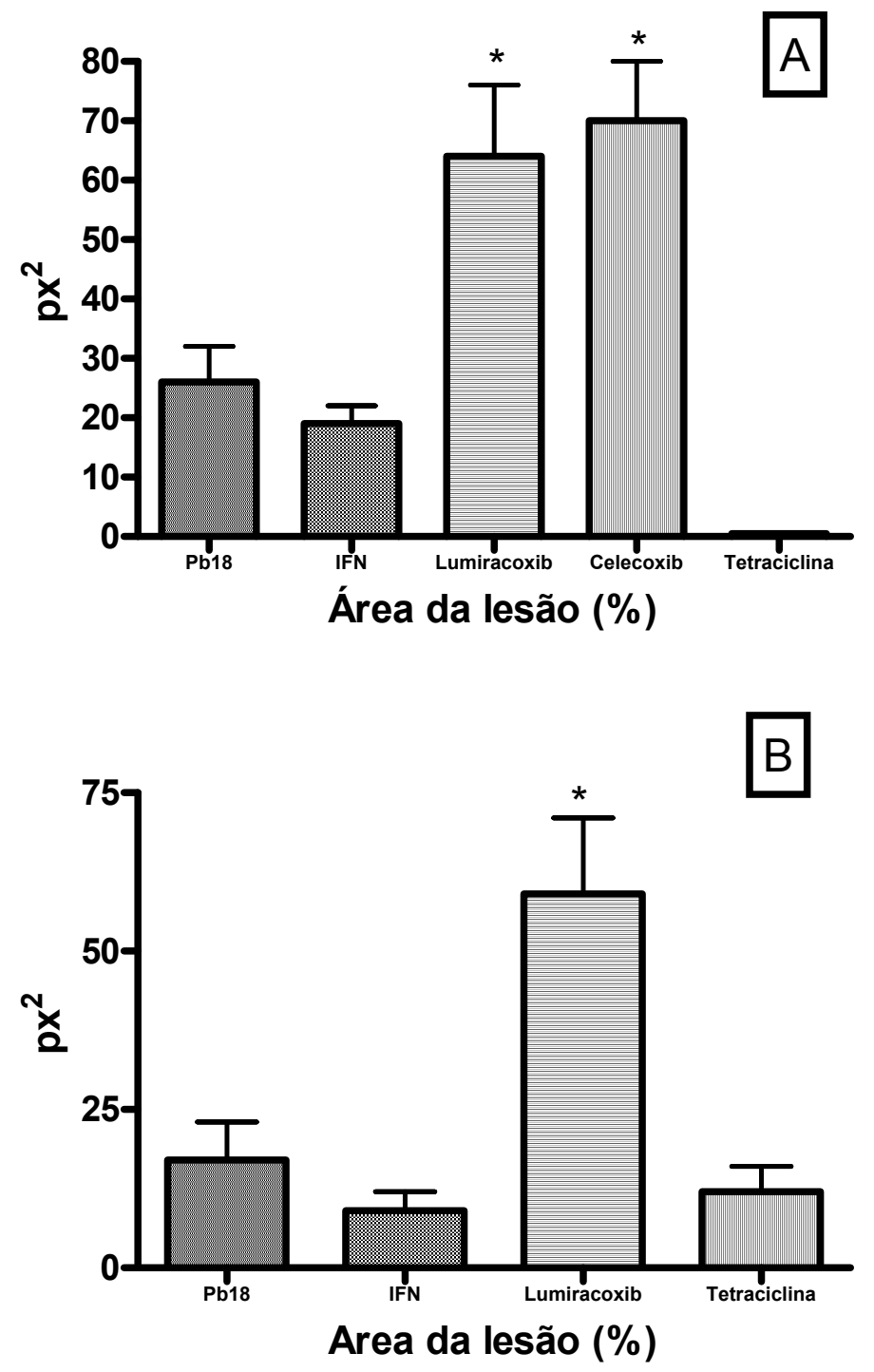

Figura 19 - Área da lesão das imagens de epíplon captadas de camundongos B10.A inoculados com Pb18 e submetido a um dos tratamentos (IFN- $\gamma$; Tetraciclina; Lumiracoxib; Celecoxib) ou apenas infectados, aos 15 dias (A) e aos 120 dias (B) de infecção. As barras representam o erro médio padrão.

- - Diferença estatística significativa com $p<0,05$ em relação aos controles apenas infectados. 

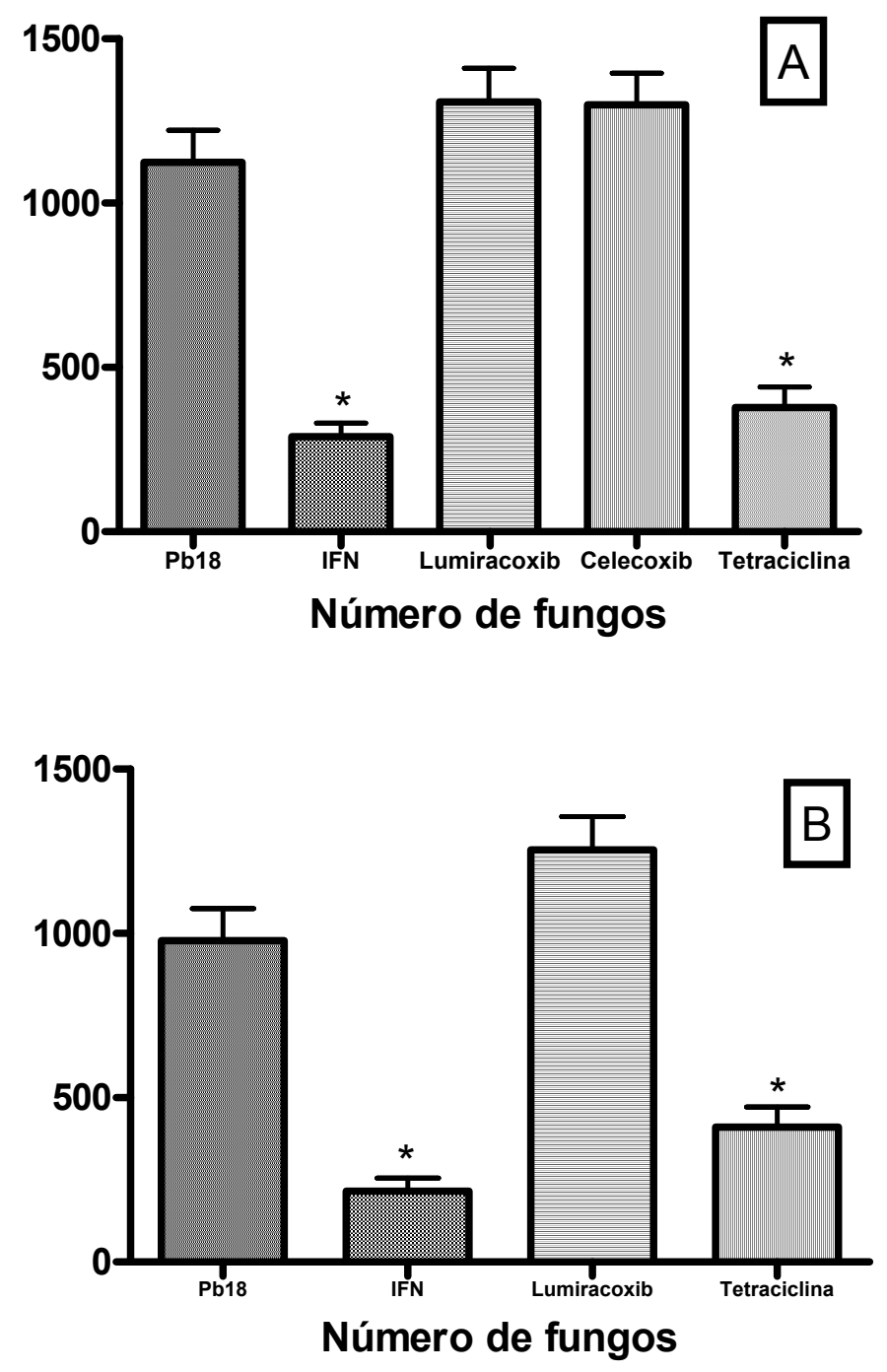

Figura 20 - Número de fungos encontrado nas imagens de epíplon captadas de camundongos B10.A inoculados com Pb18 e submetido a um dos tratamentos (IFN- $\gamma$; Tetraciclina; Lumiracoxib; Celecoxib) ou apenas infectados, aos 15 dias (A) e aos 120 dias (B) de infecção. As barras representam o erro médio padrão.

* Diferença estatística significativa com $p<0,05$ em relação aos controles apenas infectados. 

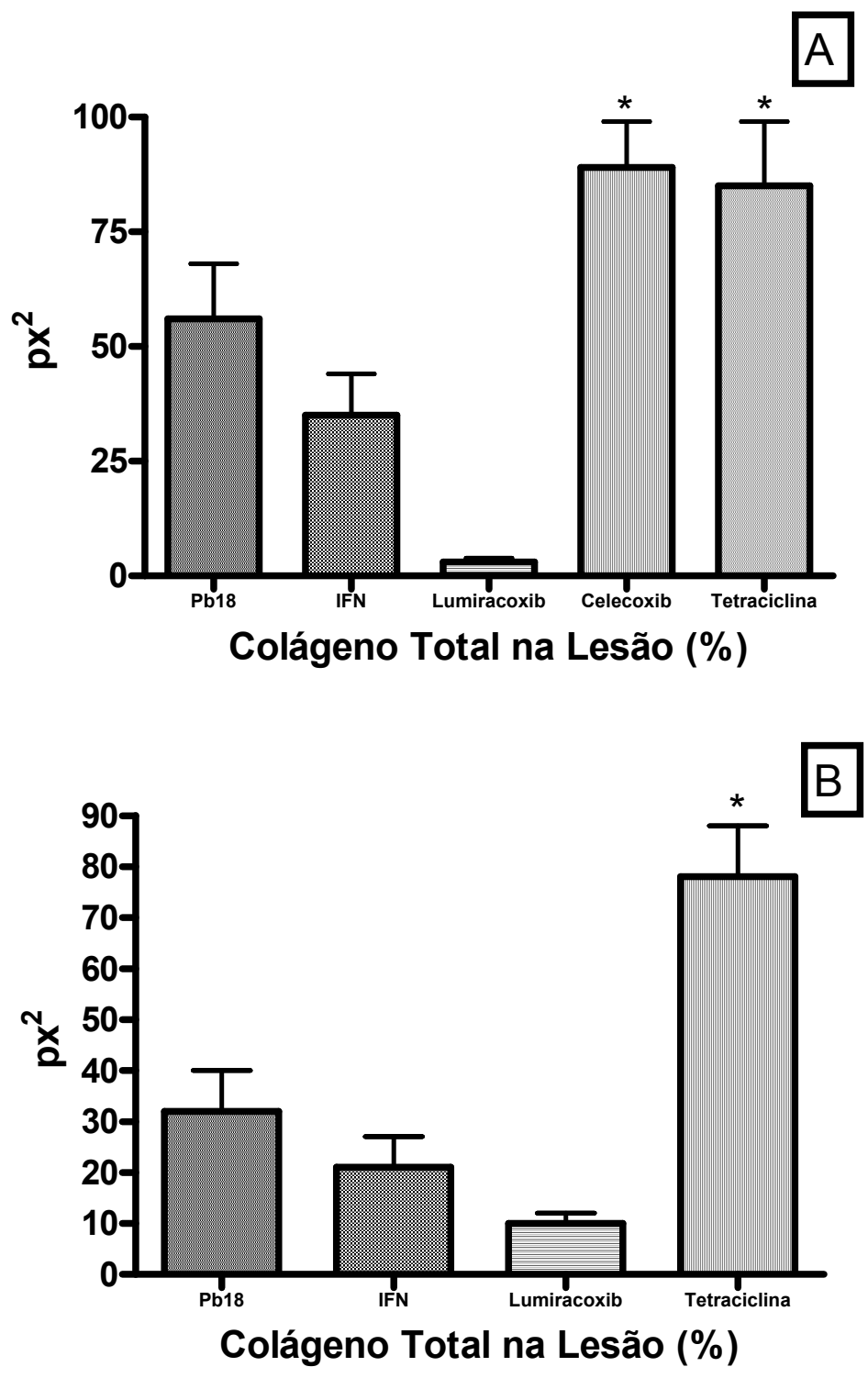

Figura 21 - Colágeno Total na lesão das imagens de epíplon captadas de camundongos $\mathrm{B} 10 . \mathrm{A}$ inoculados com $\mathrm{Pb} 18$ e submetido a um dos tratamentos (IFN- $\gamma$; Tetraciclina; Lumiracoxib; Celecoxib) ou apenas infectados, aos 15 dias (A) e aos 120 dias (B) de infecção. As barras representam o erro médio padrão.

* Diferença estatística significativa com $p<0,05$ em relação aos controles apenas infectados. 


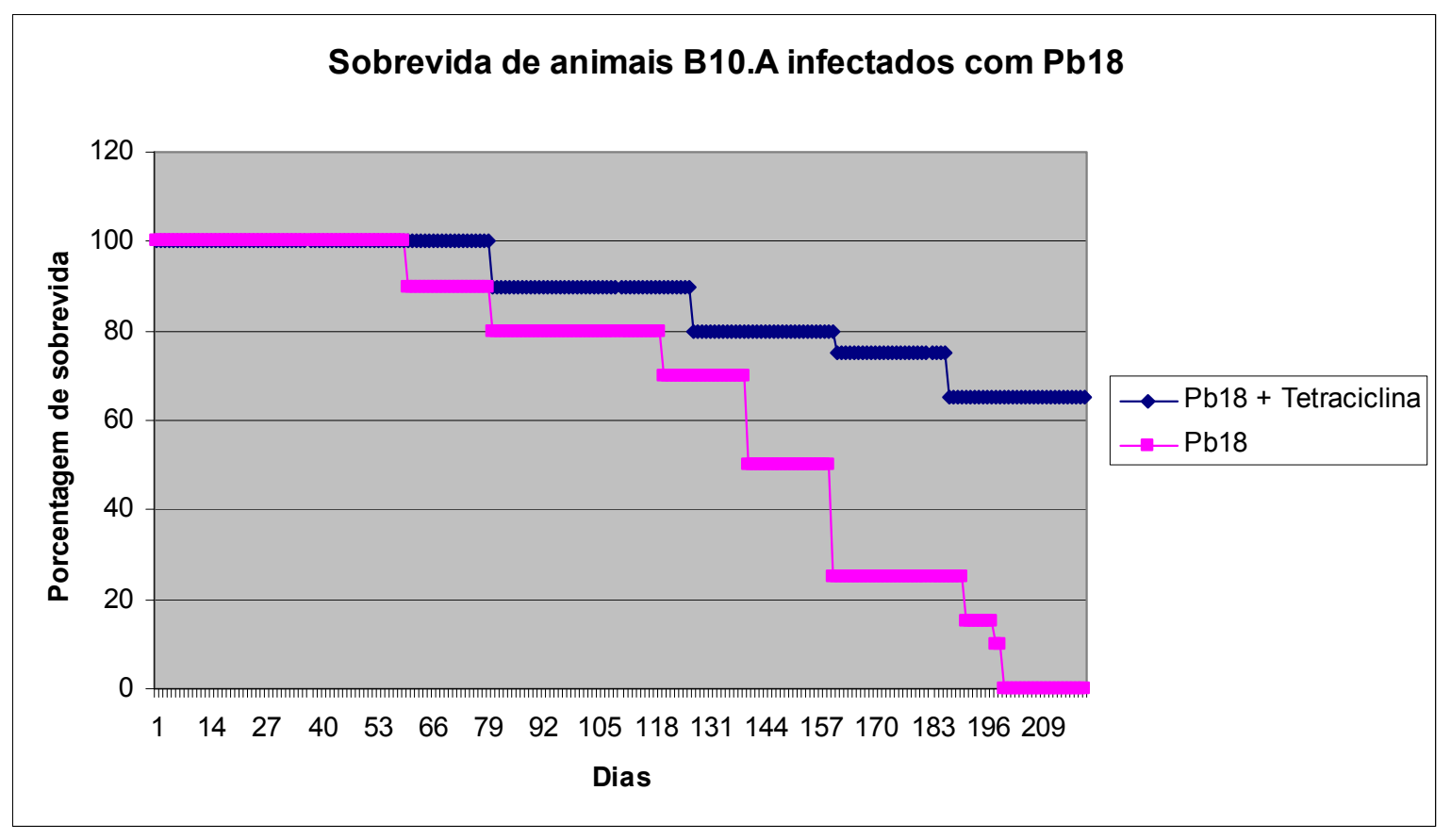

Figura 21 - Sobrevida dos camundongos B10.A inoculados com Pb18 e submetido ou não ao tratamento com Tetraciclina do dia 0 ao dia 220 após infecção. 


\section{CONCLUSÕES}

Com os resultados obtidos durante o período a que se refere o presente relatório pudemos concluir que:

- O tratamento com IFN- $\gamma$ causou uma redução da carga fúngica viável e da concentração de MMP-9 em ambos os períodos estudados. Proporcional um aumento da concentração de NO, IFN- $\gamma$ e de IL-12. Favoreceu a presença de células inflamatórias, formação de um granuloma compacto com fibras colágenas organizadas, sem alteração na concentração de hidroxiprolina e presença de células inflamatórias tanto nos animais com 15 dias de infecção, como nos animais infectados por 120 dias.

- O uso do antibiótico Tetraciclina diminuiu a viabilidade fúngica, e a concentração de MMP-9 no período inicial da infecção e aumentou a concentração de NO, GMCSF e IL-12. No período inicial de infecção não permitiu a formação de granuloma, e manteve os níveis de hidroxiprolina normais, sem que houvesse a presença de fibras colágenas, porém na lesão tardia, teve a formação de um granuloma compacto para contenção da disseminação fúngica. O tratamento com esta droga também aumentou a sobrevida dos animais com P.brasiliensis.

- O efeito da administração dos antiinflamatórios Celecoxib e Lumiracoxib foi semelhante em relação a todos os parâmetros analisados. No período de 15 dias de infecção, ambos causaram um aumento do número de $P$. brasiliensis viáveis e produção de uma baixa concentração de NO, porém elevada concentração de TNF$\alpha$. Estes tratamentos ocasionaram um aumento significativo do número de células gigantes multinucleadas, depósito de colágeno muito grande nas lesões que se apresentou desorganizado com aumento significativo da concentração de hidroxiprolina. No período de 120 dias de infecção, os animais tratados com Lumiracoxib apresentaram menor depósito de colágeno, porém as lesões continuavam frouxas e com disseminação fúngica. 


\section{REFERENCIAS}

ACORCI, M. J.; DIAS-MELICIO L. A; GOLIM, M. A; BORDON-GRACIANI, A. P.; PERAÇOLI, M. T.; SOARES, A. M. Inhibition of human neutrophil apoptosis by Paracoccidioides brasiliensis: role of interleukin-8. Scandinavian Journal of Immunology, v. 69, n. 2, p. 73-9, 2009.

BARRICK, B.; CAMPBELL, E. J.; OWEN, C. A. Leukocyte proteinases in wound healing: roles in physiologic and pathologic processes. Wound Repair and Regeneration, v. 7, n. 6, p. 410-22, 1999.

BERLINER, M. D; RECA, M. E. Vital staining of Histoplasma capsulatum with Janus Green B. Sabouraudia, v. 5, p. 26-9, 1966.

BIAGIONI, L.; SOUZA, M. J.; CHAMMA, L. G.; MENDES, R. P.; MARQUES, S. A.; MOTA, N. G.; FRANCO, M. Serology of paracoccidioidomycosis. II. Correlation between class-specific antibodies and clinical forms of the disease, Transactions of the Royal Society of Tropical Medicine and Hygiene, v. 78, n. 5, p. 617-21, 1984.

BRUMMER, E.; HANSON, L. H.; RESTREPO, A.; STEVENS, D. A. Intracellular multiplication of Paracoccidioides brasiliensis in macrophages: killing and restriction of multiplication by activated macrophages. Infection and Immunity, v. 57, p. 228994, 1989.

CALICH, V. L. G.; SINGER-VERMES, L. M.; SIQEIRA, A. M.; BURGER, E. Susceptibility and resistance of inbred mice to Paracoccidioides brasiliensis. British Journal of Experimental Pathology, v. 66, p. 585-94, 1985.

CLEMONS, K. V; LUTZ, J. E; STEVENS, D. A. Efficacy of interferon and amphotericin $B$ for treatment of systemic murine histoplamosis. Microbes and infection, v. 3, p. 3-10, 2001.

COLIGAN, J. E.; KRUISBEEK, A. M.; MARGULIES, D. H.; SHEVACH, E. M; STROBER, W. Cytokines and their cellular receptors. In: COICO, Richard (Ed.) Current Protocols in Immunology. New York: Greene, Wiley-Interscience, cap. 6, 1991.

DING, A; NATHAN, C. F; GRAYCAR, J; DERYNCK, R; STUEHR, D. J; SRIMAL, S. Macrophage deactivating factor and transforming growth factors $-\beta 1,-\beta 2$, and $-\beta 3$ inhibit induction of macrophage nitrogen oxide synthesis by IFN- $\gamma$. The Journal of Immunology, v. 145, p. 940-944, 1990.

FANTONI, D. T; CORTOPASSI, S. R. G. Técnicas anestésicas em animais de laboratório. In: De Luca RR, Alexandre SR, Marques T, Souza NL, Merusse JLB, Neves SP, editors. Manual para técnicos em bioterismo. $2^{a}$ ed. São Paulo: WinnerGraph, p. 157-65, 1996.

*De acordo com: ASSOCIAÇÃO BRASILEIRA DE NORMAS TÉCNICAS. NBR 6023: 109 Informação e Documentação: referências: elaboração. Rio de Janeiro, 2002. 
FISHER, L. W; STUBBS, J. T; YOUNG, M. F. Antisera and cDNA probes to human and certain animal model bone matrix noncollagenous proteins. Acta Orthopaedica Scandinavica, v. 266, p. 61-5, 1995.

FONTANA, V. A; SANCHEZ, M; CEBRAL, E; CALVO, J. C. Interferon-gamma Inhibits Metalloproteinase Activity and Cytotrophoblast Cell Migration. American Journal of Reproductive Immunology, v. 28, p. 20-6, 2010.

FRANCO, L; NAJVAR, L; GOMES, B. L; GRAYBILL, J. R; RESTREPO, A. Experimental pulmonary fibrosis induced by Paracoccidioides brasiliensis conidia: measurement of local host responses. American Journal of Tropical Medicine and Hygiene, v. 58, n. 4, p. 424-430, 1998.

GHOSH, S. K. A study on the present scenario of STD management in an urban clinic in Kolkata. Indian Journal Of Dermatology, Venereology and Leprology, v. 68, n. 2, p. 82-3, 2002.

GROCOTT, R. G. A strain for fungi in tissue sections and smears, using Gomori's methanamine-silver nitrate technic. American Journal of Clinical Pathology, v. 25, p. 975-979, 1955.

HADDAD, $\mathrm{H}$; KARAKA, L; STABHOLZ, A; SOSKOLNE, A; SHAPIRA, L. Tetracycline conditioning augments the in vivo inflammatory response by cementum extracts. Journal of Periodontology ONLINE, v. 75, p. 388-92, 2004.

HARRING, C. F. J. Licensure and membership. The Journal of the American Dental Association, v. 133, n. 3, p. 270, 2002.

HOJBERG, J; SHORE, S; KOBZIK, L; OKINGA, S; HALLOCK, A; VALLONE, J; SUBRAMANIAM, V; SANCTIS, G. T. D; ELIAS, J. A; DRAZEN, J. M; SILVERMAN, E. S. Expression of nitric oxide synthase-2 in the lungs decreases airway resistance and responsiveness. Journal of Applied Physiology, v. 97, p. 249-59, 2004.

HUREWITZ, A. N; WU, C. L; MANCUSO, P; ZUCKER, S. Tetracycline and doxycycline inhibit pleural fluid metalloproteinases. A possible mechanism for chemical pleurodesis. Chest, v. 103, n. 4, p. 1113-7, 1993.

JIMENEZ, S. A; FREUNDLICH, B; ROSENBLOOM, J. Selective inhibition of human diploid fibroblast collagen synthesis by interferons. The Journal of Clinical Investigation, v. 74, n. 3, p. 1112-6, 1984. 
JUNQUEIRA, L. C. U; BIGNOLAS, C; BRENTANI, R. Picrosirius staining plus polarization microscopy, a specific method for collagen detection in tissue sections. Histochemical Journal, v. 11, p. 447-455, 1979.

KASHINO, S. S; CALICH, V. L. G; BURGER, E; SINGER-VERMES, L. M. In vivo and in vitro characteristics of six Paracoccidioides brasiliensis strains. Mycopathologia, v. 95, p. 173-8, 1985.

KASHINO, S. S; SINGER-VERMES, L. M; CALICH, V. L. G; BURGER, E. Alteration in the pathogenicity of one Paracoccidioides brasiliensis isolates in susceptible inbred mice. Journal of Medical and Veterinary Mycology, v. 111, p. 173-80, 1990.

KASHINO, S. S; FAZIOLI, R. A; CAFALLI-FAVATI, C; MELONI-BRUNERI, L. H; VAZ, C. A; BURGER, E; SINGER, L. M; CALICH, V. L. Resistance to Paracoccidioides brasiliensis infection is linked to a preferential Th1 immune response, whereas susceptibility is associated with absence of IFN-gamma production. Journal of Interferon Cytokine Rsearch, v. 20, p. 11-20, 2000.

KERR, I. B; OLIVEIRA, P. C; LENZI, H. L. Connective matrix organization in chronic granulomas of experimental paracoccidioidomycosis. Mycopathologia, v. 103, n. 1, p. 11-20, 1988.

KONNO, A. Y; MARICATO, J. T; KONNO, F. T; MARIANO, M; LOPES, J. D. Peptides from Paracoccidioides brasiliensis GP43 inhibit macrophage functions and inflammatory response, Microbes and Infection, v. 11, n. 1, p. 92-9, 2009.

KURIHARA, Y; HATORI, M; ANDA, Y; ITO, D; TOYOSHIMA, T; TANAKA, M. Inhibition of cyclooxygenase-2 suppresses the invasiveness of oral squamous cell carcinoma cell lines via down-regulation of matrix metalloproteinase-2 production and activation. Clinical \& Experimental Metastasis, v. 26, p. 425-32, 2009.

KURITA, N; BISWAS, M; OARADA, A; SANO, K; NISHIMURA, K; MIYAJI, M. Fungistatic and fungicidal activities of murine polymorphonuclear leucocytes against yeast cells of Paracoccidioides brasiliensis. Medical Mycology, v. 37, n. 1, p. 19-24, 1999.

LANGE, M; MÁLYUSZ, M. Improved determination of small amounts of free hudroxyproline in biological fluids. Clinical Chemistry, v. 40, n. 9, p. 1735-1738, 1994.

LARKINS, T. L; NOWELL, M; SINGH, S; SANFORD, G. L. Inhibition of cyclooxygenase-2 decreases breast cancer cell motility, invasion and matrix metalloproteinase expression. BMC Cancer, v. 6, p. 181, 2006. 
LENZI, H. L; OLIVEIRA, D. N; LIMA, M. T; GATTASS, C. R. Trypanosoma cruzi: paninfectivity of $C L$ strain during murine acute infection. Experimental Patology, v. 84, n. 1, p. 16-27, 1996.

MELONI-BRUNERI, L. H; CAMPA, A; ABDALLA, D. S; CALICH, V. L; LENZI, H. L; BURGER, E. Neutrophil oxidative metabolism and killing of $P$. brasiliensis after air pouch infection of susceptible and resistant mice. Journal of Leukocyte Biology, v. 59, n. 4, p. 526-33, 1996.

MI, W. L; MAO-YING, Q. L; LIU, Q; WANG, X. W; WANG, Y. Q; WU, C. G. Synergistic anti-hyperalgesia of electroacupuncture and low dose of celecoxib in monoarthritic rats: Involvement of the cyclooxygenase activity in the spinal cord. Brain Research Bulletin, v. 77, p. 98-104, 2008.

MOLINA, R. F. S; SCAVONE, R; NISHIKAKU, A. S; CUNHA, C; BURGER, E. Effects on neutrophils migration, activation state and fungicidal activity of cycloxygenase inhibitors in the murine model of paracoccidioidomycosis: comparative study with celecoxib and Lumiracoxib. In: $13^{\text {th }}$ International Congress of Immunology. Rio de Janeiro, Brasil, Resumo, p. 145 (P1691), 2007.

MOREIRA, A. P; DIAS-MELICIO, L. A; PERAÇOLI, M. T. S; CALVI, S. A; SOARES, A. M. V. C. Killing of Paracoccidioides brasiliensis yeast cells by IFN- $\gamma$ and TNF- $\alpha$ activated murine peritoneal macrophages: evidence of $\mathrm{H} 2 \mathrm{O} 2$ and $\mathrm{NO}$ effector mechanisms. Mycopathologia, v. 166, p. 17-23, 2008.

MUSATTI, C. C; REZKALLAH M. T; MENDES, E; MENDES, N. F. In vivo and in vitro evaluation of cell-mediated immunity in patients with paracoccidiodomycosis, Cellular Immunology, v. 24, n. 2, p. 365-78, 1976

NAKAMURA, H; MASUKO, K; YUDOH, K; KATO, T; NISHIOKA, K. Effects of celecoxib on human chondrocytes--enhanced production of chemokines. Clinical and Experimental Rheumatology, v. 25, n. 1, p. 11-6, 2009.

NIEMANTSVERDRIET, M; DE JONG, E; LANGENDIJK, J. A; KAMPINGA, H. H; COPPES, R. P. Synergistic induction of profibrotic PAI-1 by TGF-beta and radiation depends on p53. Radiotherapy and Oncology, 2010.

NISHIKAKU, A. S; BURGER, E. Immunohististochemical analysis of collagen isotypes in granulomatous lesions in an experimental model of paracoccidioidomycosis. Procediment Trends Medical Mycology Supply, v. 1, p. 26-30, 2003.

NISHIKAKU, A; RIBEIRO, L. C; MOLINA, R. F; ALBE, B. P; CUHA, C. S; BURGER, E. Matrix metalloproteinases with gelatinolytic activity induced by Paracoccidioides brasiliensis infection. Internetional Journal of Experimental Pathology. v. 90, p. 527-37, 2009. 
PAIXÃO-CAVALCANTE, D; VAN DEN BERG, C. W; GONÇALVES DE ANDRADE, R. $\mathrm{M}$; FERNANDEZ PEDROSA, F; OKAMOTO, C. K; TAMBOURGI, D. V. Tetracycline protects against dermonecrosis induced by Loxosceles spider venom. Journal of Investigation Dermatology, v. 127, p. 1410-8, 2007.

PALLASCH, T. Subantimicrobial doses of Tetracycline. Arteriosclerosis, Thrombosis, and Vascular Biology, v. 24, p. 163, 2004.

PASTERNAK, B; ASPENBERG, P. Metalloproteinases and their inhibitors-diagnostic and therapeutic opportunities in orthopedics. Acta Orthopaedica, v. 80 (6), p. 693703, 2009.

PLATELL, C; COOPER, D; PAPADIMITRIOU, J. M; HALL, J. C. The Omentum, World Journal of Gastroenterology, v. 6, n. 2, p. 169-176, 2000.

QUAN, T; HE, T; SHAO, Y; LIN, L; KANG, S; VOORHEES, J. J; FISHER, G. J. Elevated cysteine-rich 61 mediates aberrant collagen homeostasis in chronologically aged and photoaged human skin. The American Journal of Pathology, v. 169, n. 2, p. 482-90., 2006.

RODRIGUES, D. R; DIAS-MELICIO, L. A; CALVI, S. A; PERAÇOLI, M. T. S; SOARES, A. M. V. C. Paracoccidioides brasiliensis killing by IFN-, TNF- and GMCSF activated human neutrophils: role for oxygen metabolites. Medical Mycology, v. 45, p. 27-33, 2007.

SANCÉAU, J; BOYD, D. D; SEIKI, M; BAUVOIS, B. Interferons inhibit tumor necrosis factor-alpha-mediated matrix metalloproteinase-9 activation via interferon regulatory factor-1 binding competition with NF-kappa B. Journal of Biological Chemistry, v. 277, n. 38, p. 35766-75, 2002.

SCIULLI, M. G; CAPONE, M. L; TACCONELLI, S; PATRIGNANI, P. "The future of traditional nonsteroidal anti-inflammatory drugs and cyclooxygenase-2 inhibitors in the treatment of inflammation and pain". Pharmacologial Reports, v. 57, p. 66-85, 2005.

SIME, P. J; XING, Z; GRAHAM, F. L; CSAKY, K. G; GAULDIE, J. Adenovectormediated gene transfer of active transforming growth factor-beta1 induces prolonged severe fibrosis in rat lung. The Journal of Clinical Investigation, v. 100, n. 4, p. 768-76, 1997

SINGER-VERMES, L. M; CIAVAGLIA, M. C; KASHINO, S. S; BURGER, E; CALICH, V. L. G. The source of the growth promoting factor affects the platting efficiency of $P$. brasiliensis. Journal of Medical and Veterinary Mycology, v. 30, p. 261-264, 1992. 
SOTO-SUAZO, M; ABRAHAMSOHN, P. A; PEREDA, J; SAN MARTIN, S; NADER, H. B; SAMAPIO, L. O; ZORN, T. T. Modulation of hyaluronan in the migratory pathway of mouse primordial germ cells. Histochemistry and Cell Biology, v. 117, n. 3, p. 265-7, 2002.

SOUTO, J. C; ALMASY, L; BORREL, M; BLANCO-VACA, F; MATEO, J; SORIA, J. M; COLL, L; FELICES, R; STONE, W; FONTCUBERTA, J; BLANGERO, J. Genetic susceptibility to thrombosis and its relationship to physiological risk factors: the GAIT study. Genetic Analysis of Idiopathic Thrombophilia. The American Journal of Human Genetics, v. 67, n. 6, p. 1452-9, 2000.

TAFLIN, C; MIYARA, M; NOCHY, D; VALEYRE, D; NACCACHE, J. M; ALTARE, F; SALEK-PEYRON, P; BADOUAL, C; BRUNEVAL, P; HAROCHE, J; MATHIAN, A; AMOURA, Z; HILL, G; GOROCHOY, G. FoxP3+ regulatory T cells suppress early stages of granuloma formation but have little impact on sarcoidosis lesions. American Journal of Pathology, v. 174, n. 2, p. 497-508, 2009.

TAMAI, K; ISHIKAWA, H; MAUVIEL, A; UITTO, J. Interferon-gamma coordinately upregulates matrix metalloprotease (MMP)-1 and MMP-3, but not tissue inhibitor of metalloproteases (TIMP), expression in cultured keratinocytes. The Journal of Investigative Dermatology, v. 104, n. 3, p. 384-90, 1995.

VADAY, G. C; FRANITZA, S; SCHOR, H; HECHT, I; BRILL, A; CAHALON, L; HERSHKOVIZ, R; LIDER, O. Combinatorial signals by inflammatory cytokines and chemokines mediate leukocyte interactions with extracellular matrix. Journal of Leukocyte Biology, v. 69, n. 6, p. 885-92, 2001.

WANG, J. L; CHENG, H. F; SHAPPELL, S; HARRIS, R. C. A selective cyclooxygenase-2 inhibitor decreases proteinuria and retards progressive renal injury in rats. Kidney International, v. 57, p. 2334-42, 2000.

WYNN, T. A; THOMPSON, R. W; CHEEVER, A. W; MENTINK-KANE, M. M. Immunopathogenesis of schistosomiasis. Immunological Reviews, v. 201, p. 15667, 2004.

ZAR, J. H. Biostatistical analysis. $2^{\text {nd }}$ ed. New Jersey: Prentice Hall, 1984. 